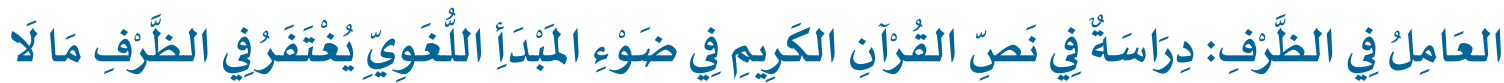

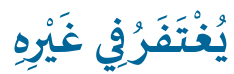

\author{
حمدي محمود جبالي

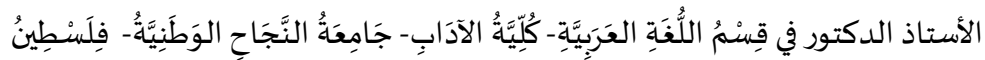 \\ hamdi.jabali@najah.edu
}

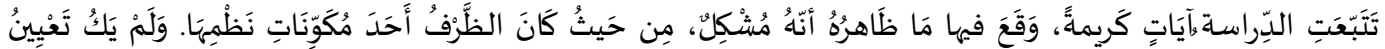

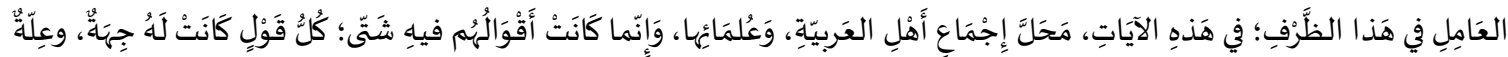

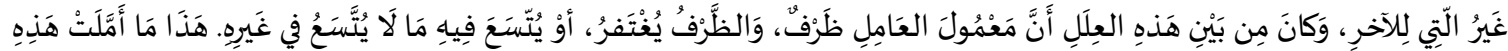

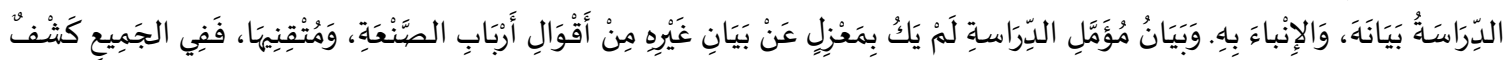

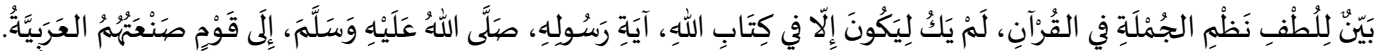

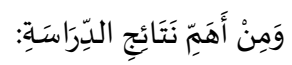

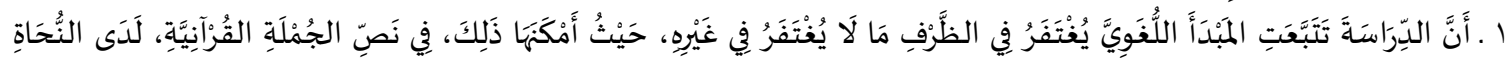

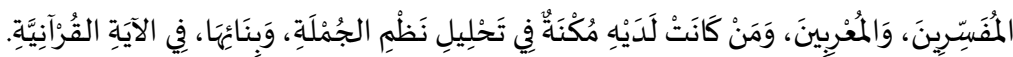

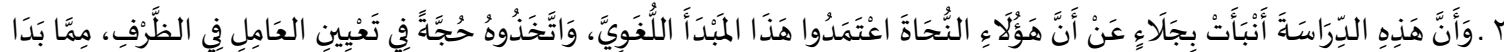

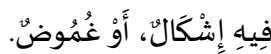

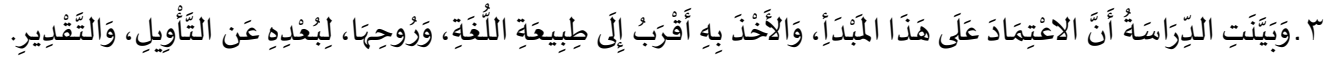

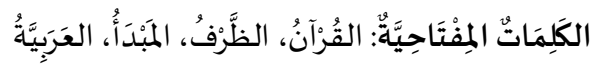

\title{
(9) (1)
}

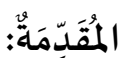

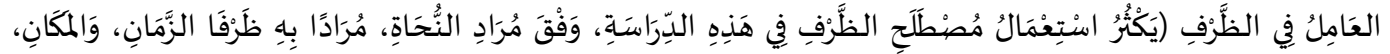

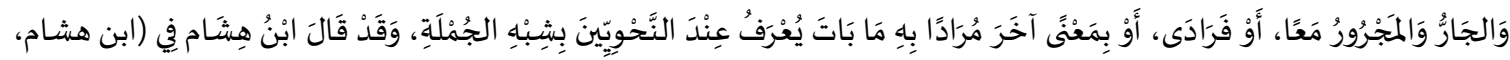

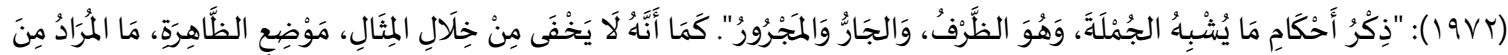

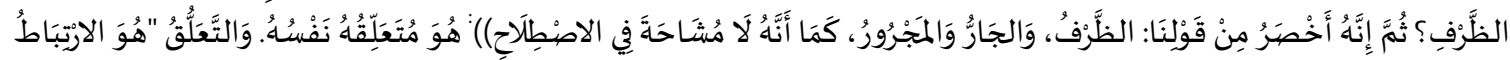

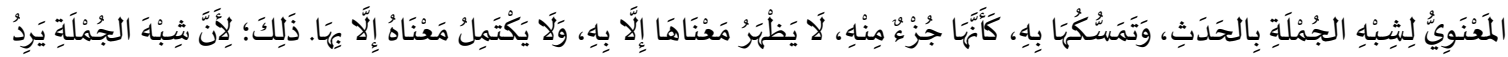

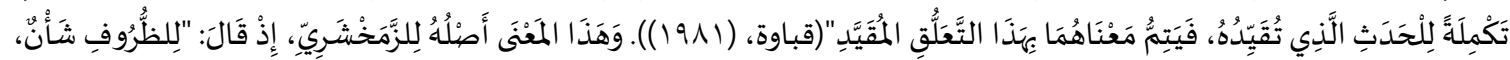

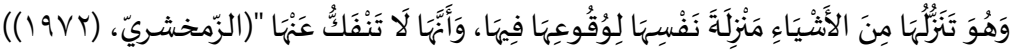

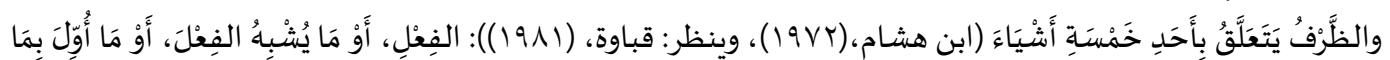

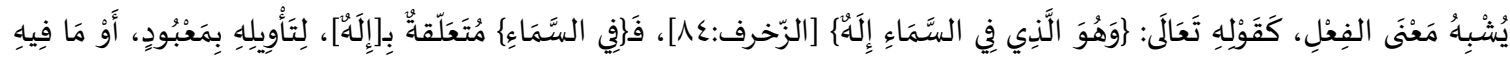

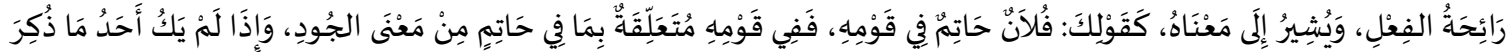

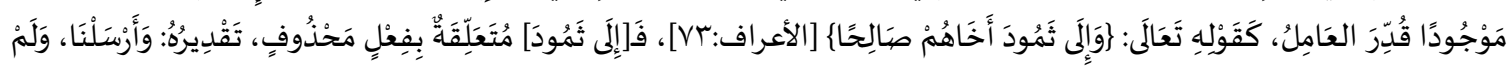

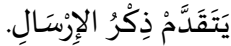

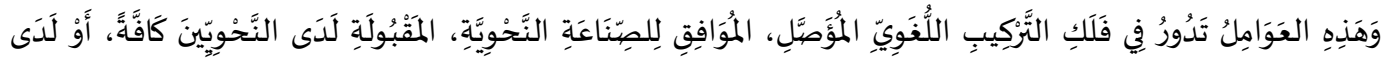

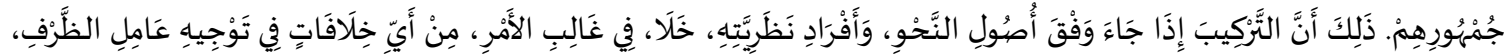




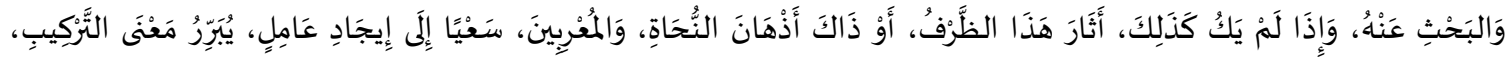

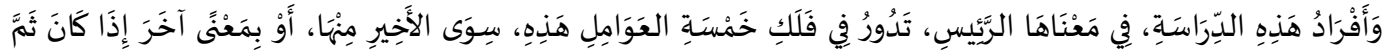

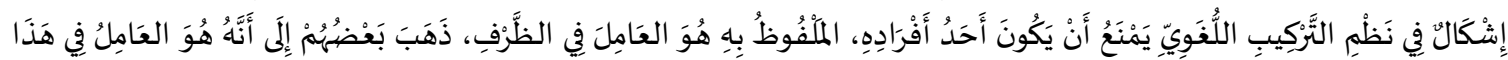

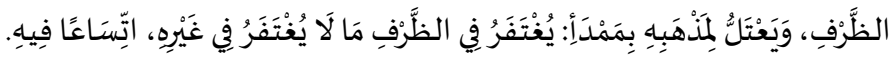

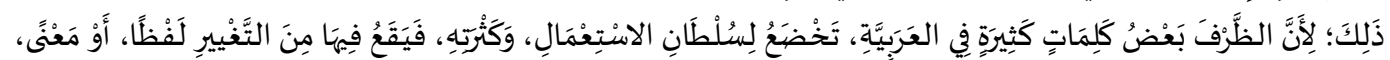

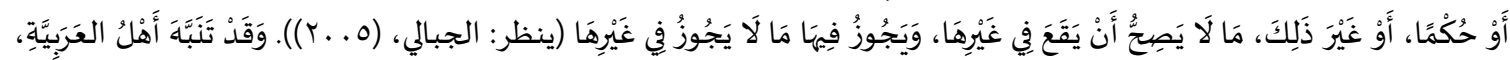

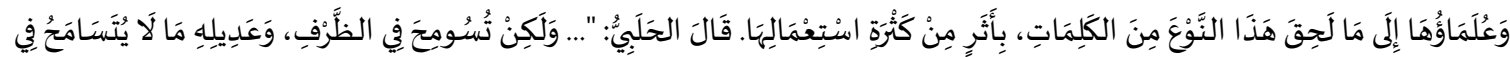

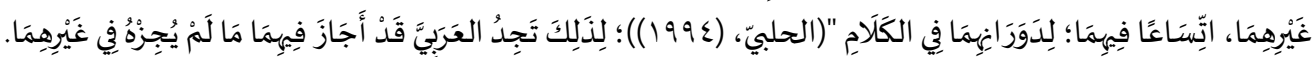

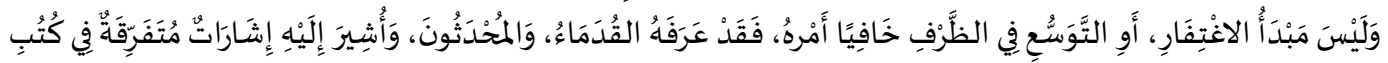

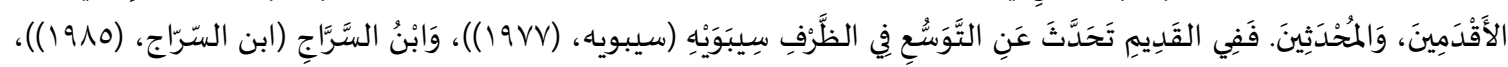

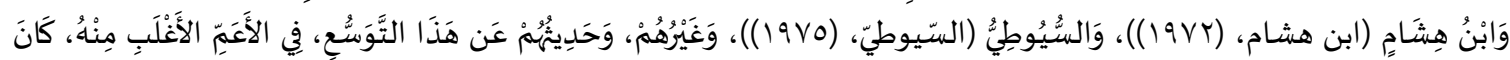

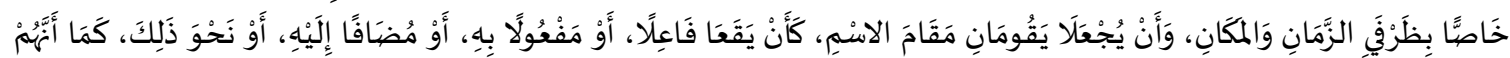

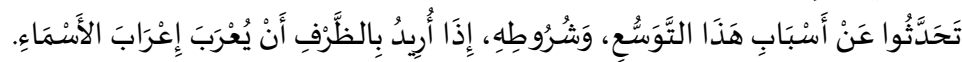

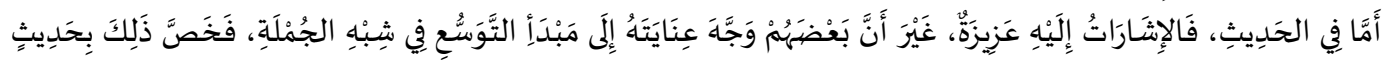

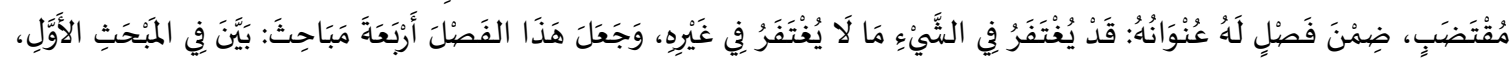

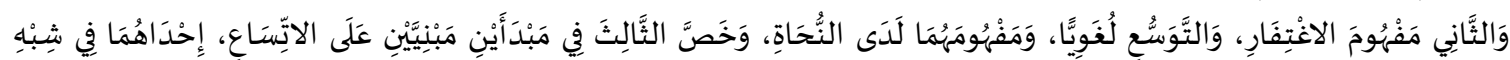

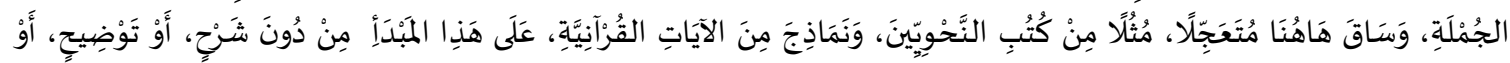

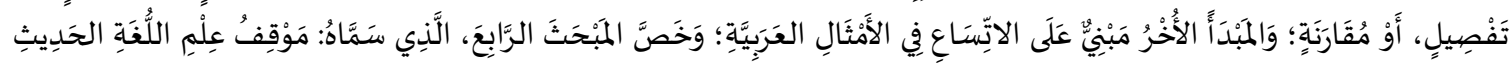

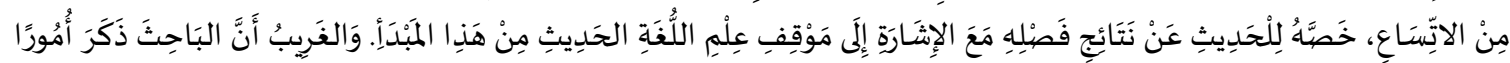

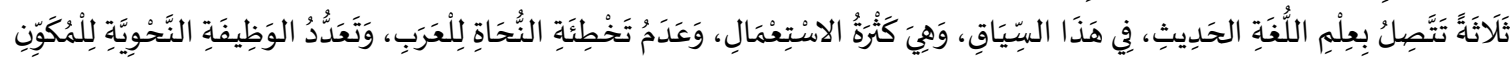

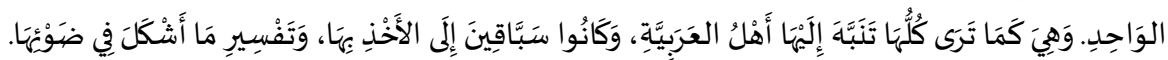

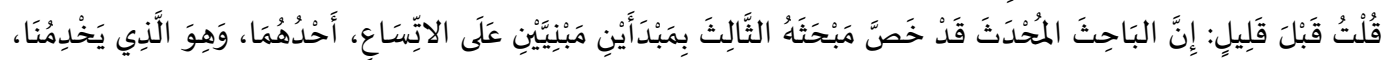

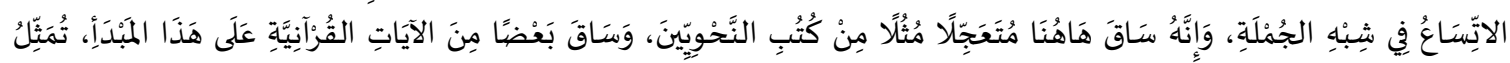

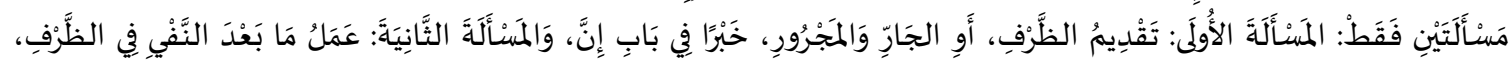

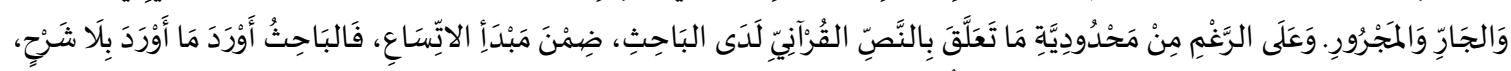

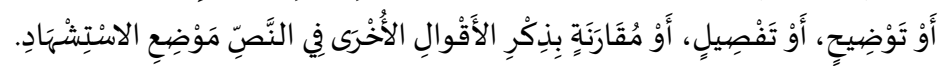

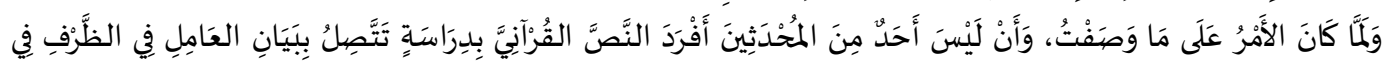

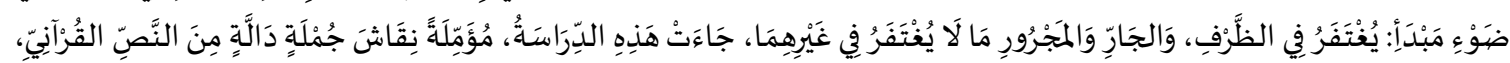

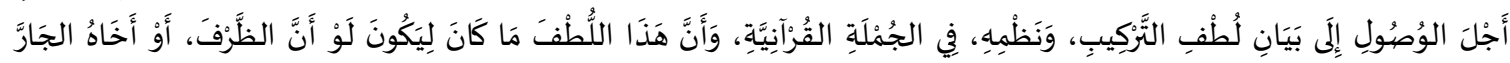

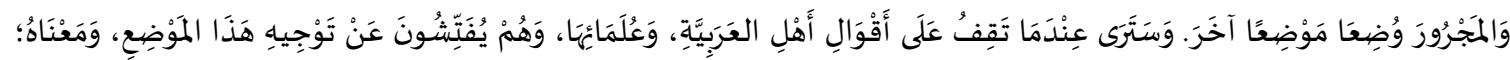

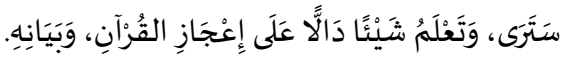

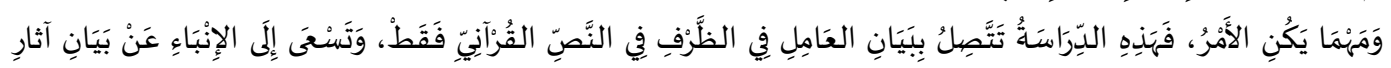

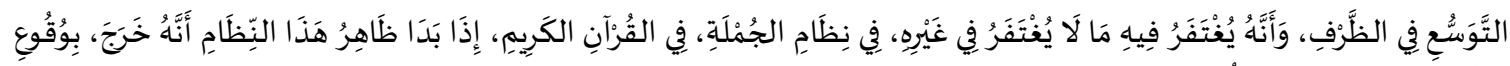

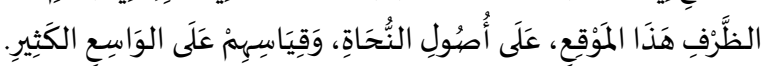

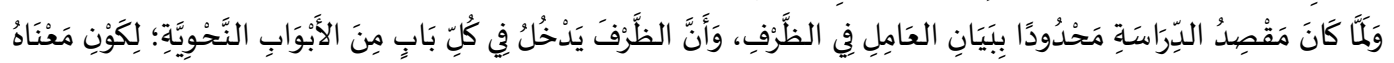

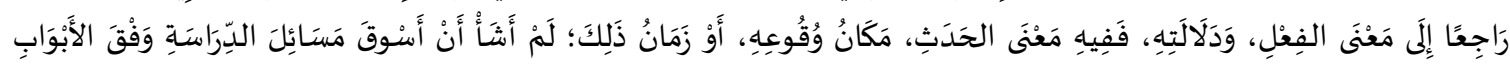

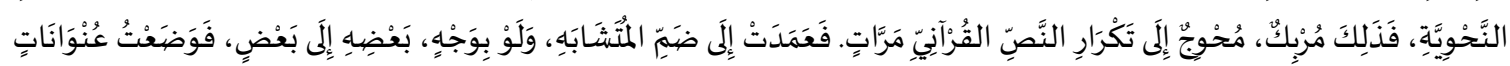

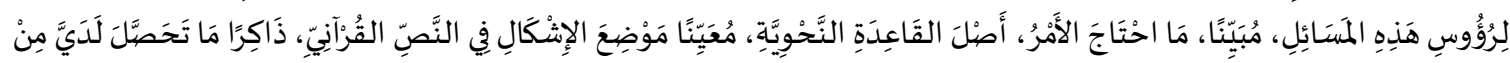

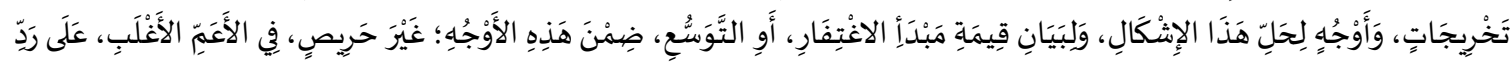

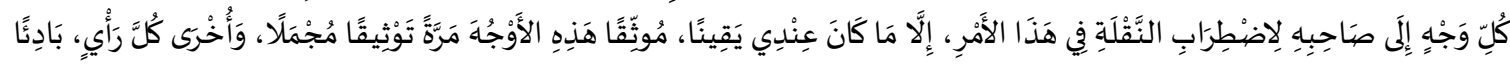




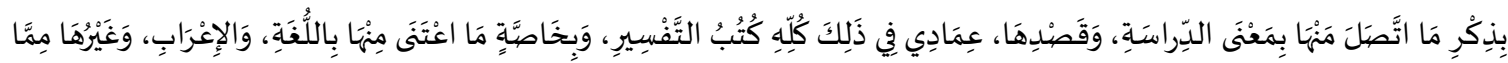

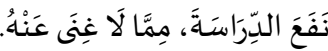

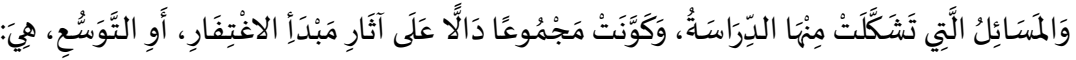

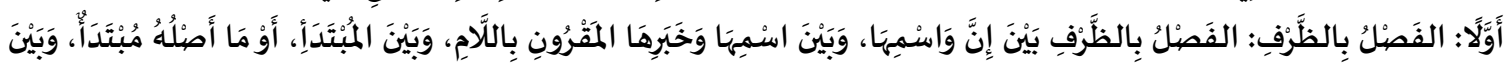

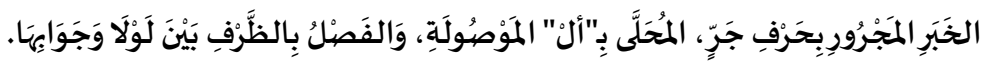

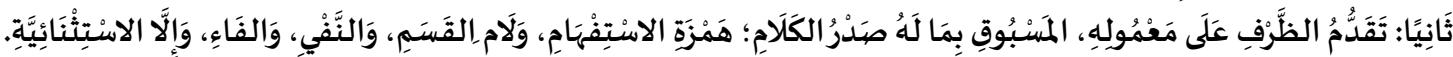

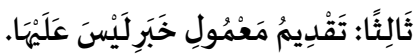

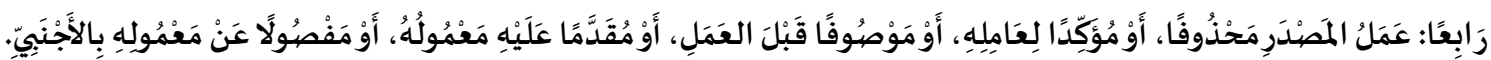

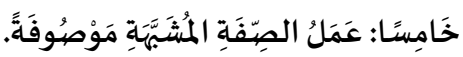

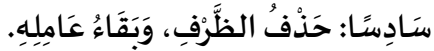

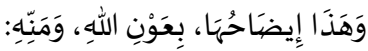

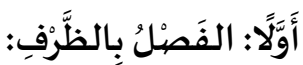

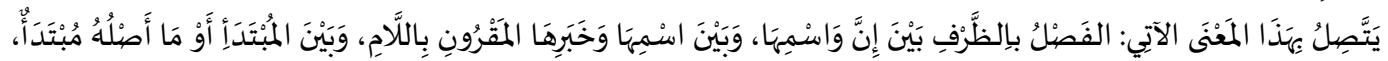

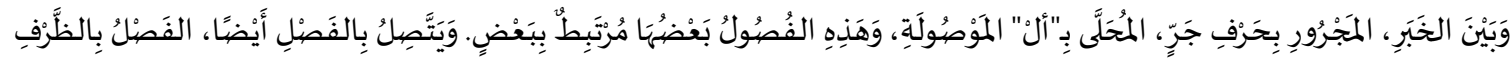

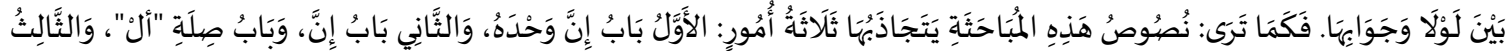

لَوَلَا وَجَوَوَابُهَا.

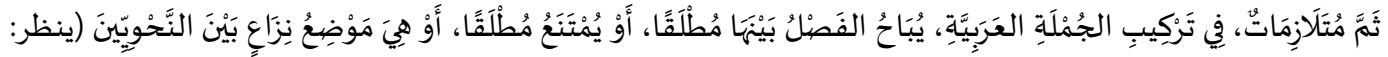

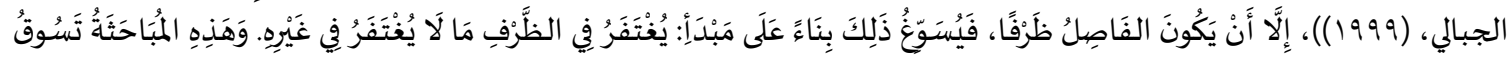

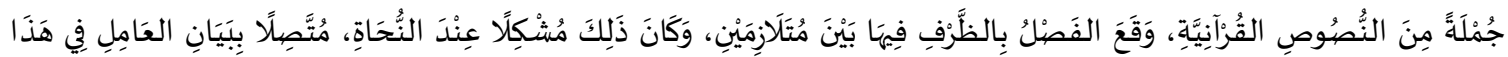
الظَّرْفِ من

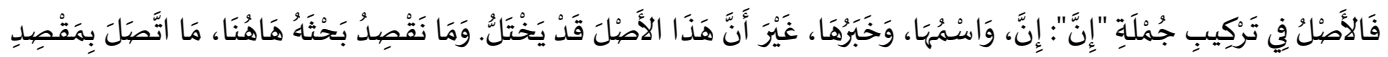

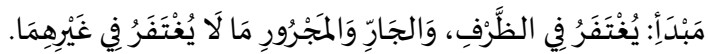

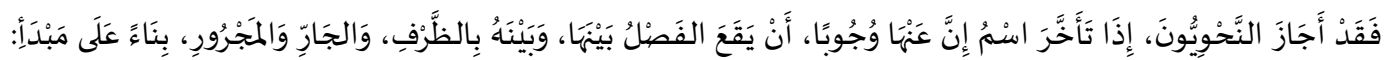

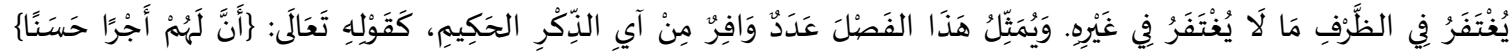

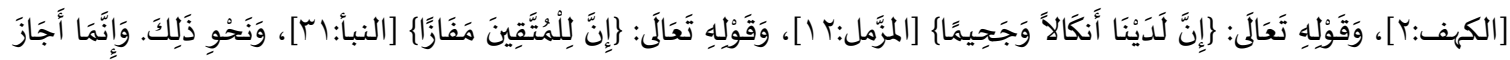

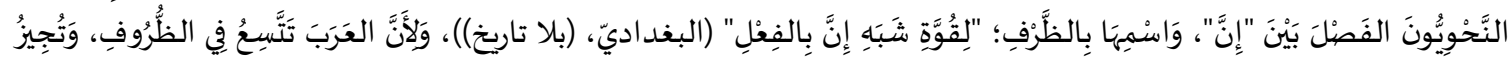

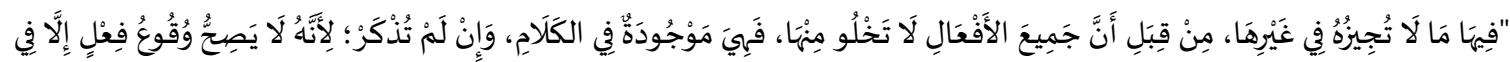

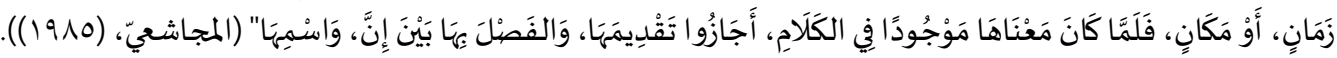

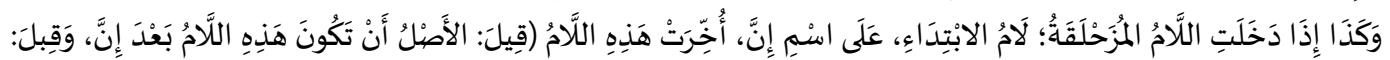

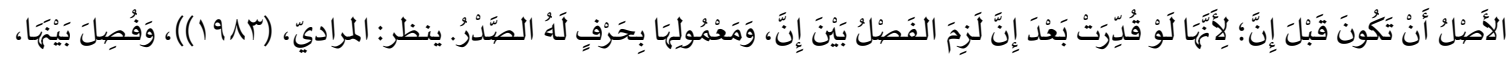

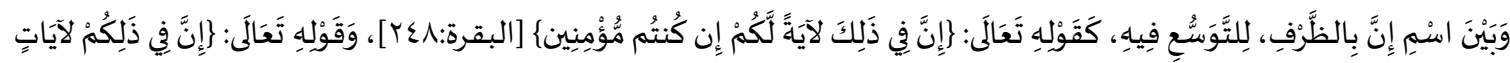

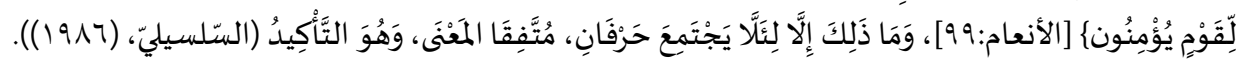

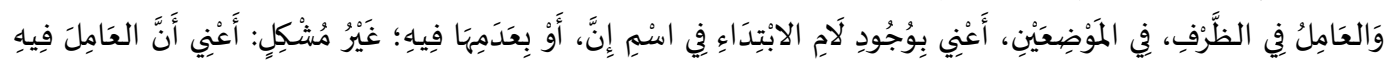

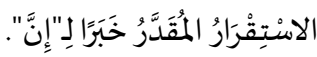

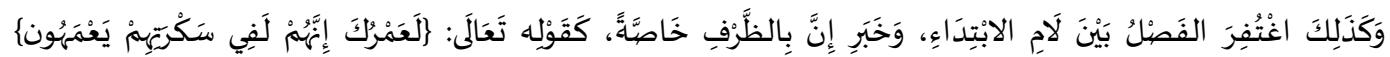

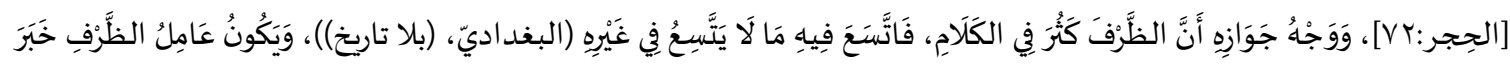

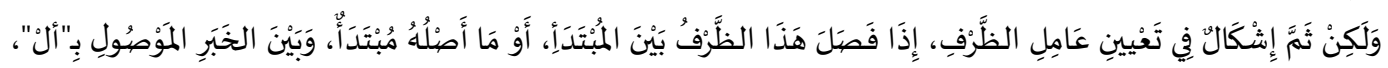

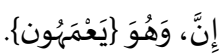

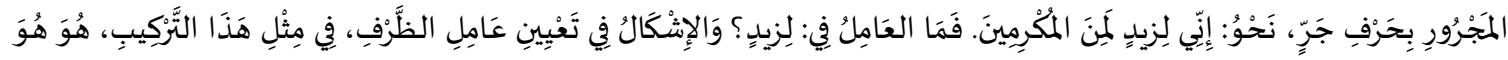

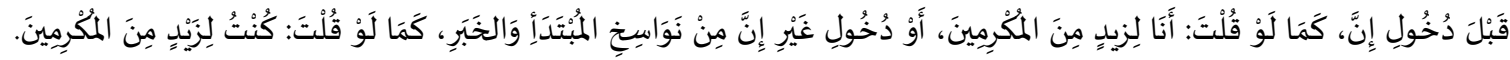




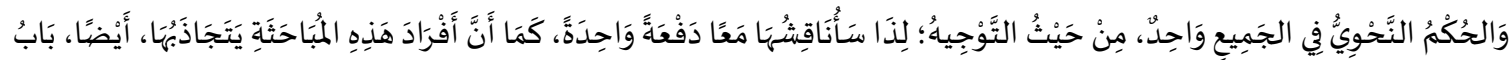

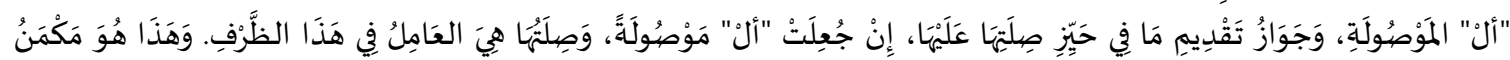

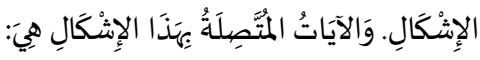

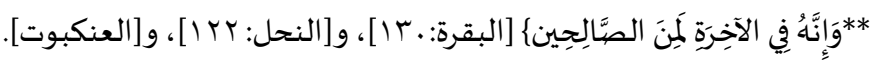

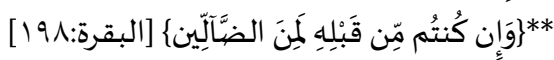

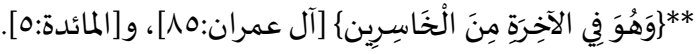

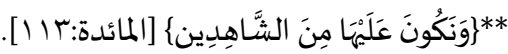

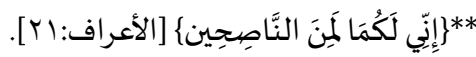

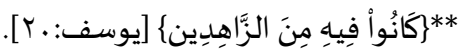

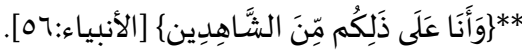

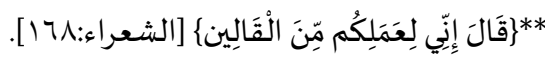

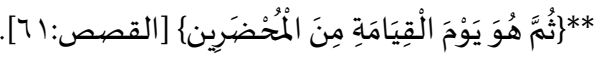

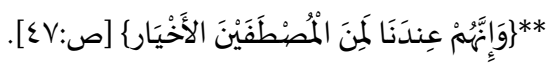

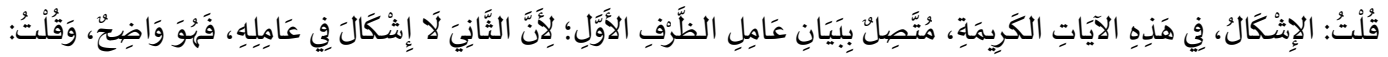

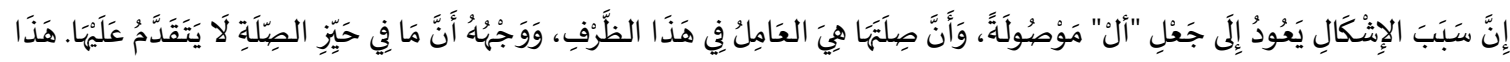

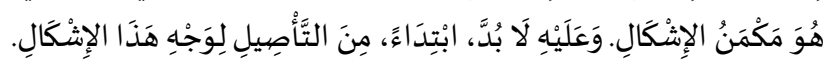

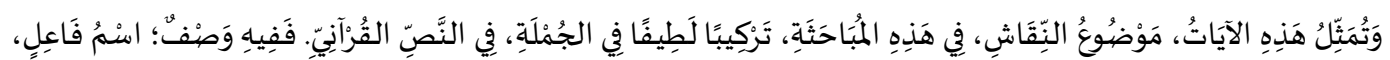

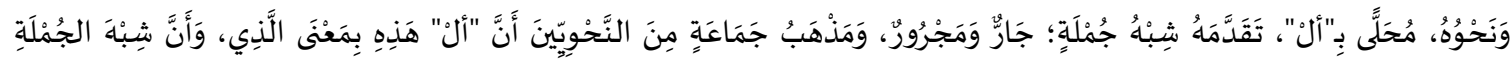

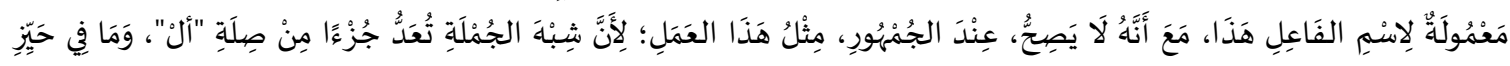

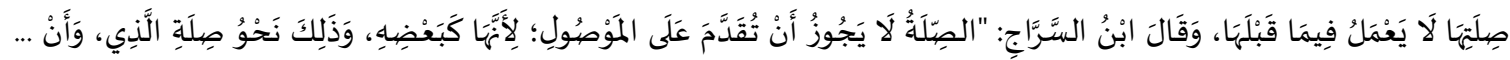

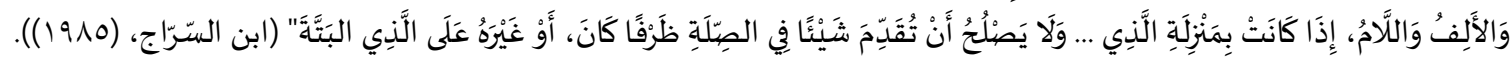

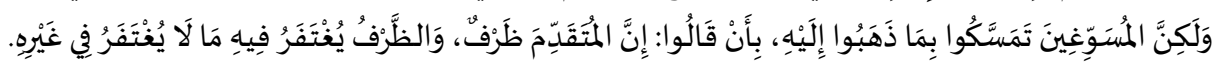

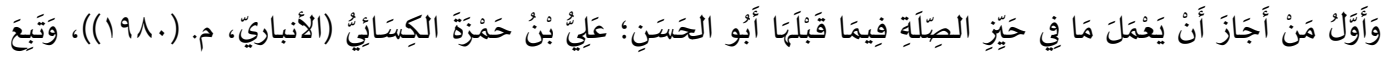

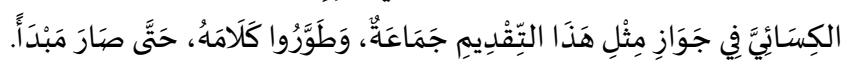

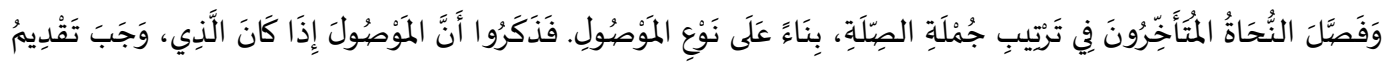

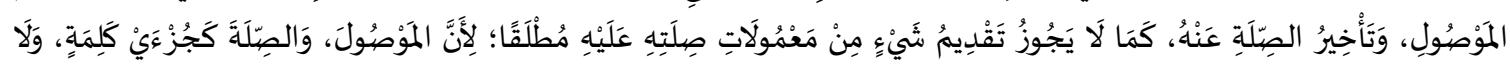

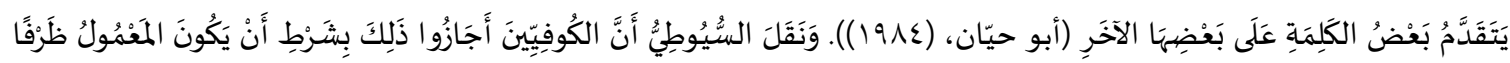
(السيوطي، (19v9)).

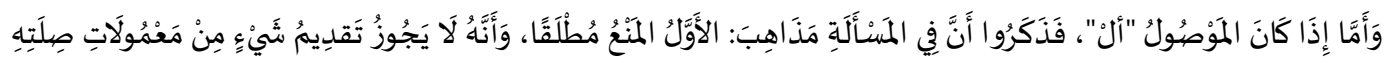

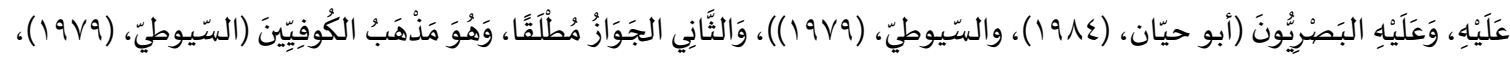

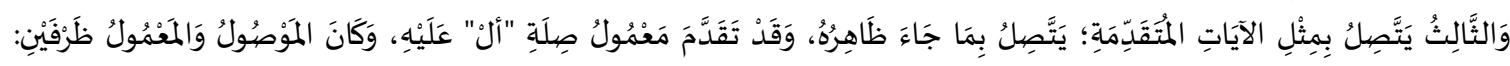

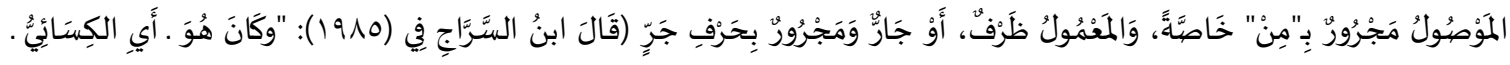

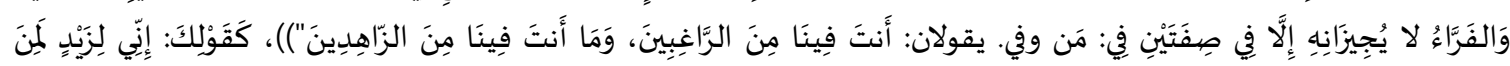

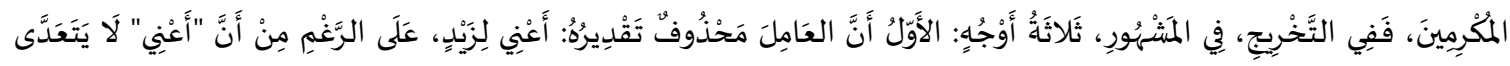

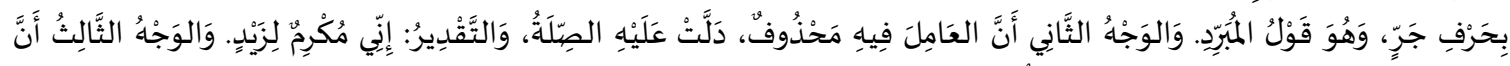

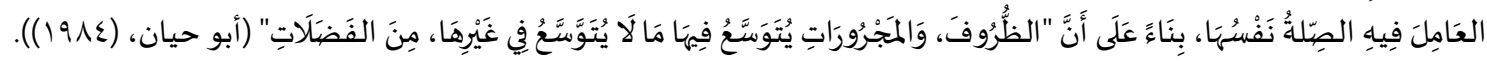

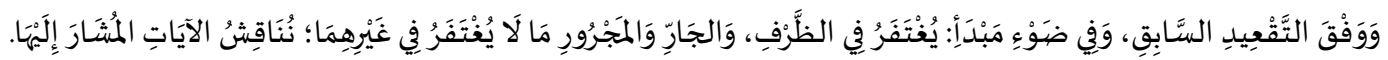

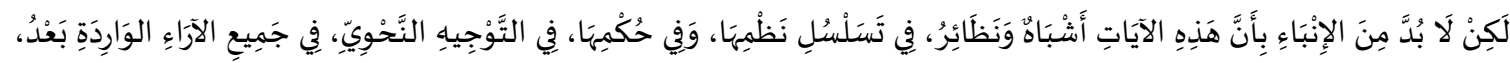

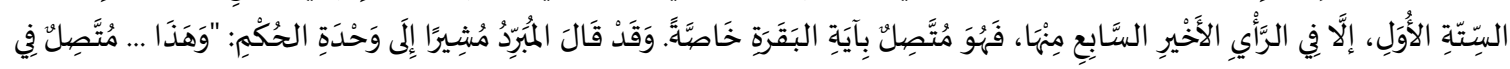

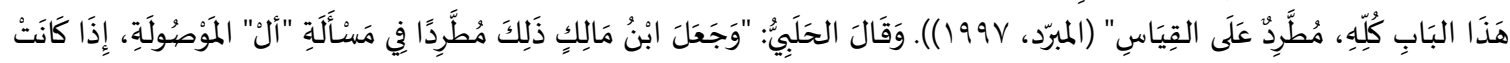

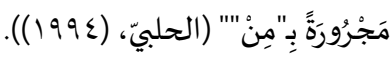




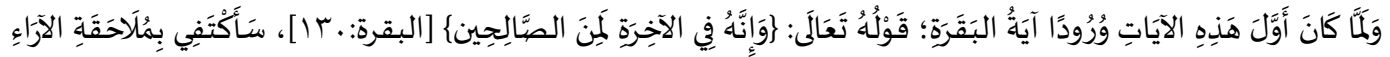

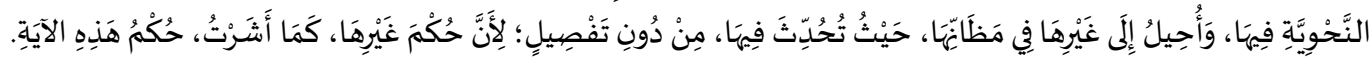

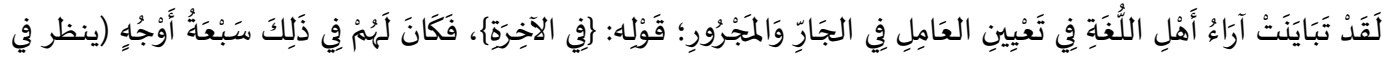
هذه الأوجه: العكبريّ، (بلا تاريخ)، وأبو حيّان، (بلا تاريخ):

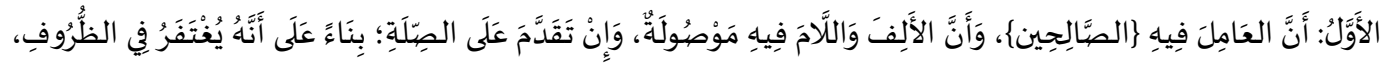

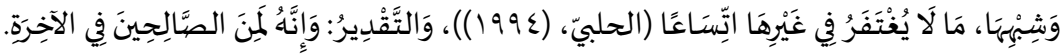

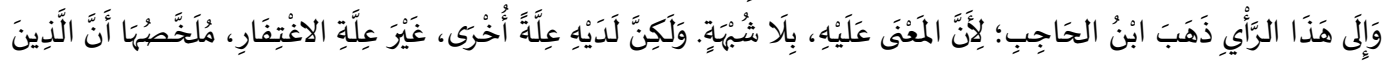

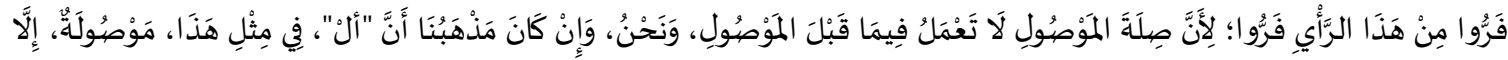

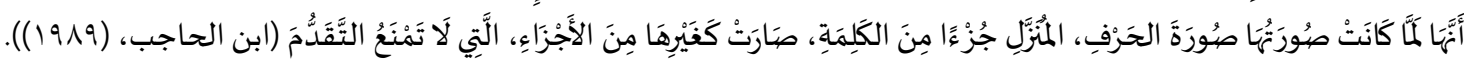

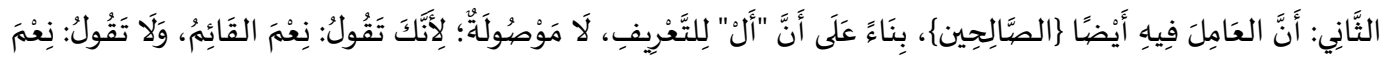

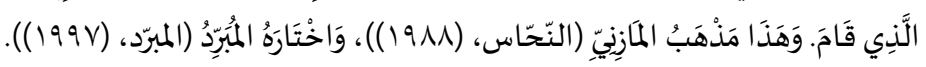

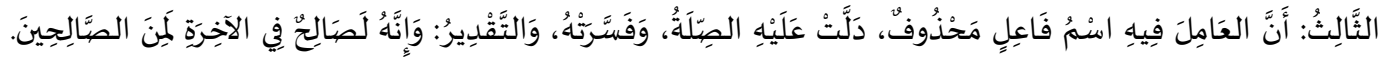

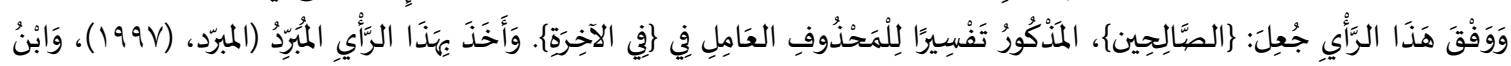

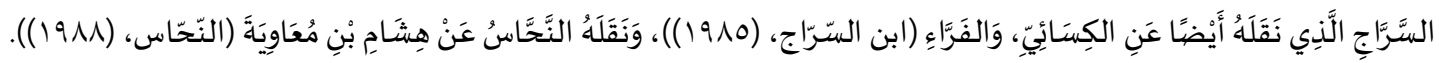

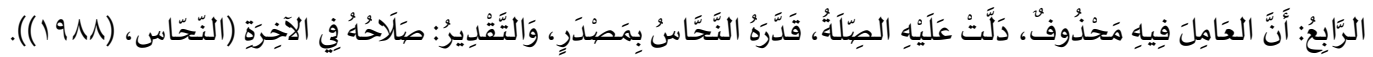

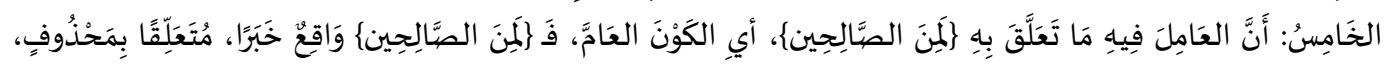

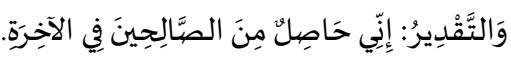

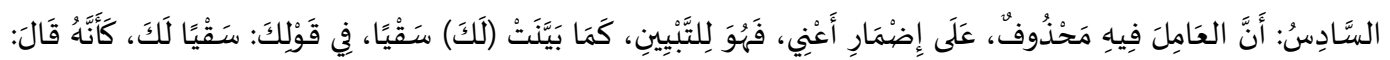

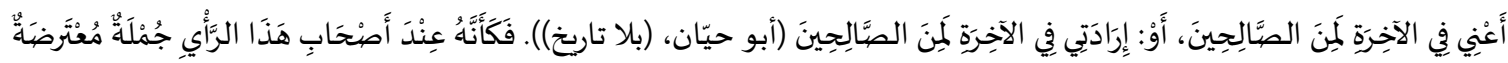

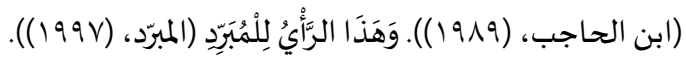

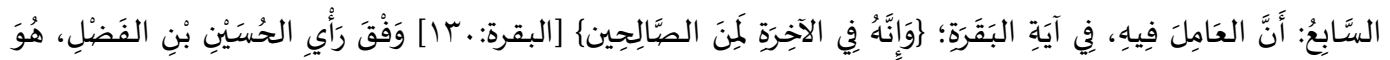

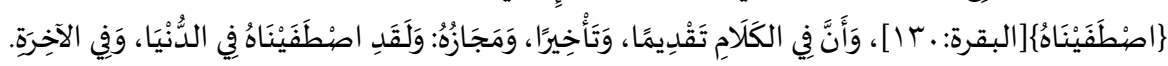

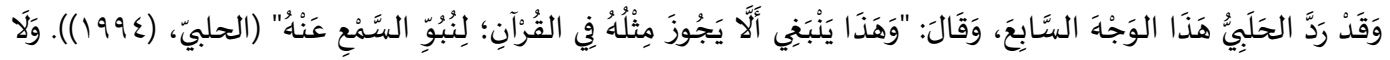

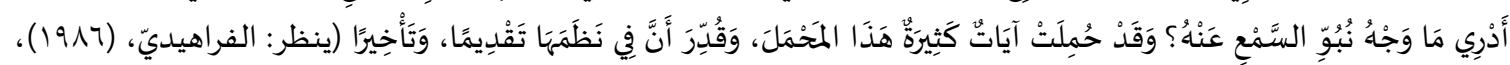

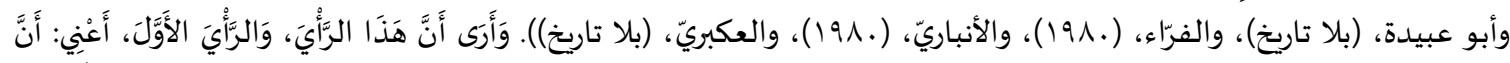

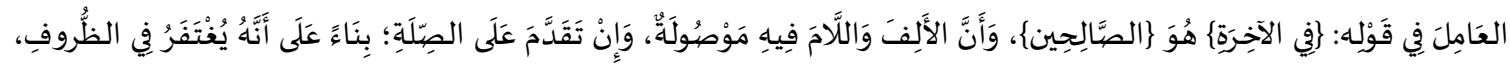

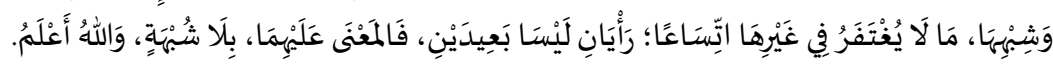

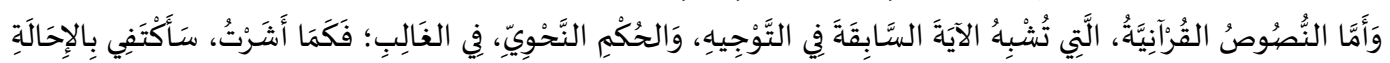

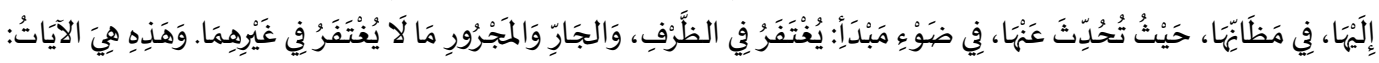

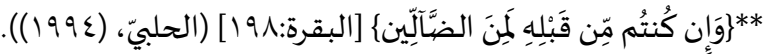

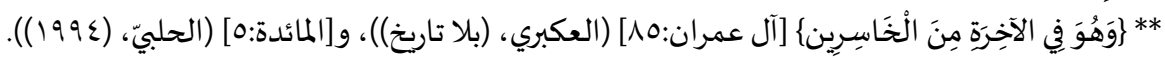

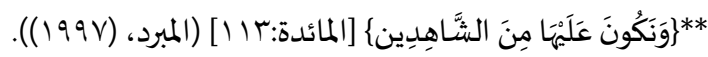

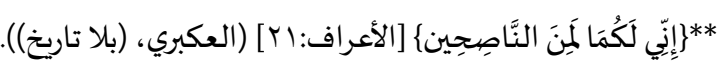

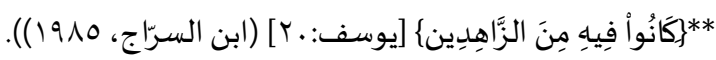

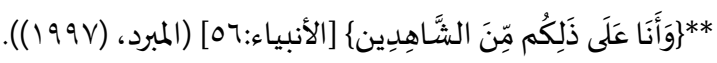

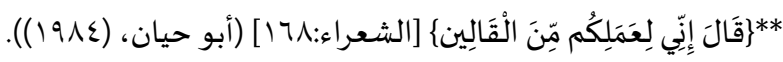

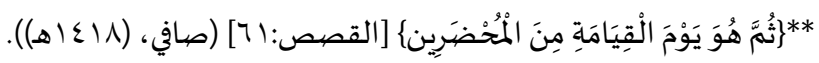

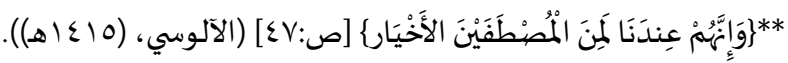

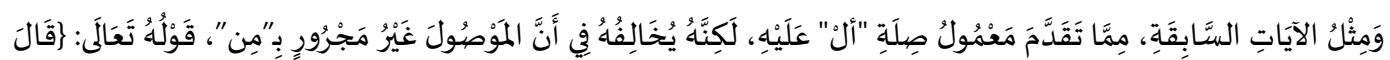

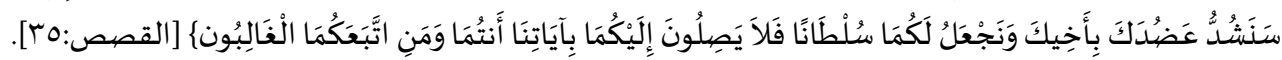




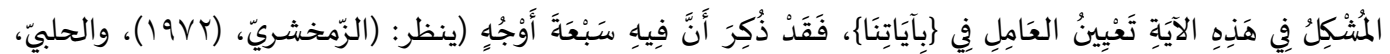

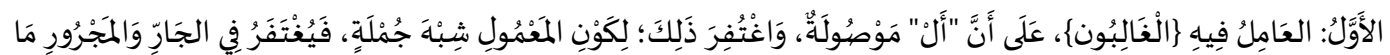

لَا يُغْتَفَرُ فِيَ غَيْرِه.

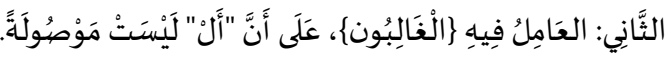

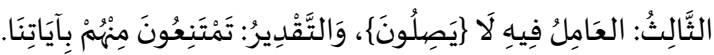

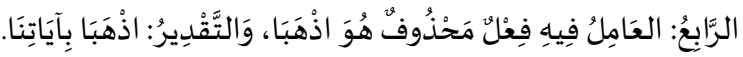

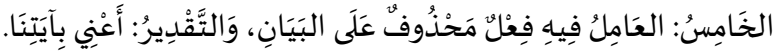

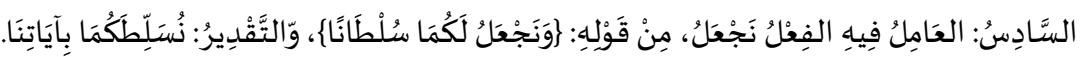

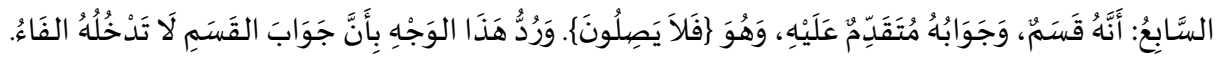

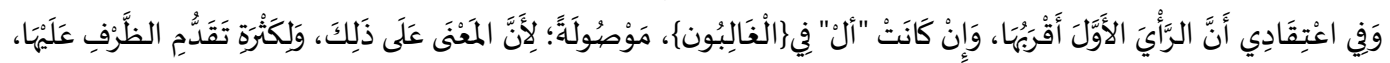

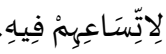

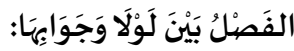

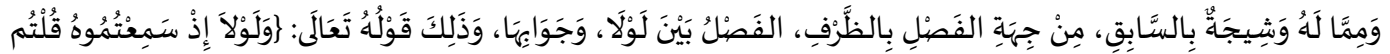

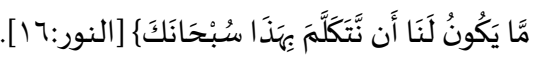

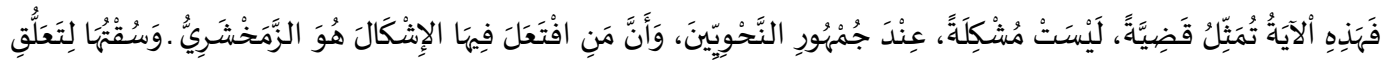

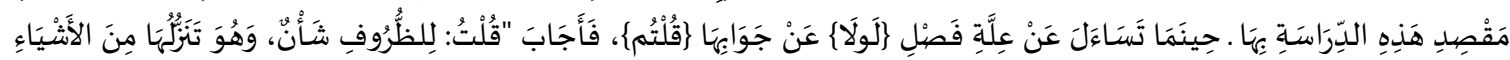

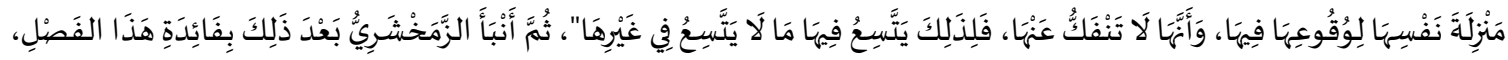

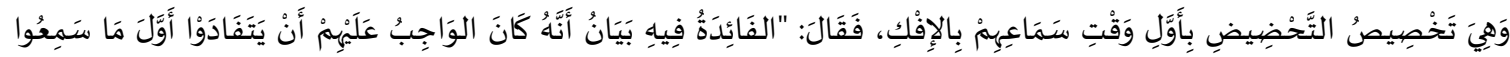

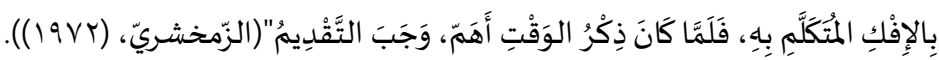

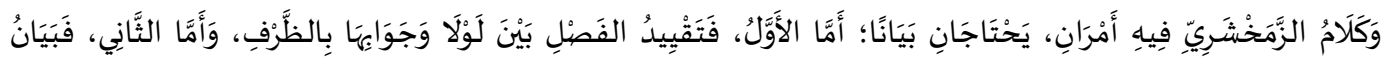

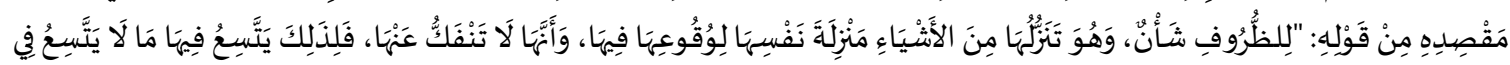

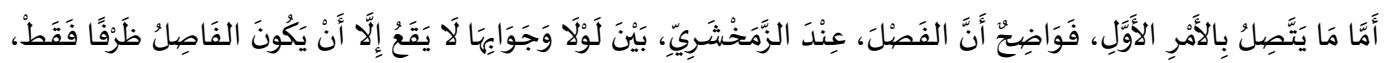

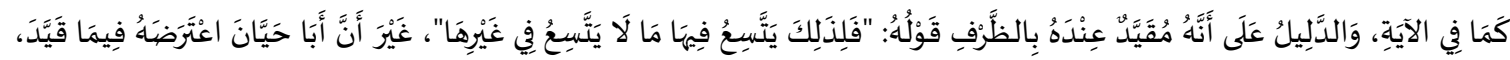

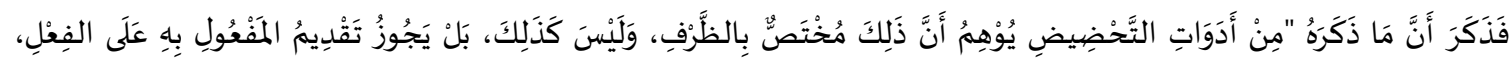

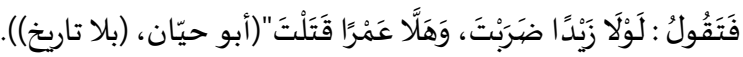

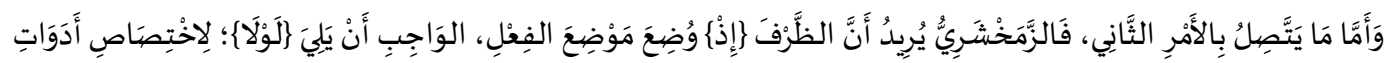

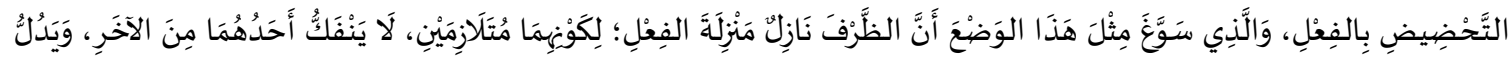

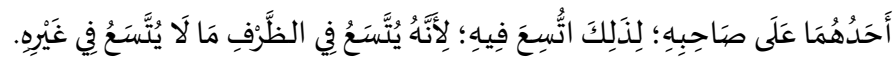

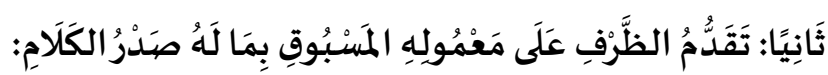

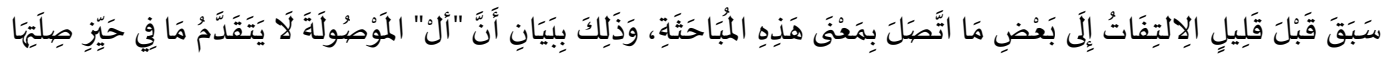

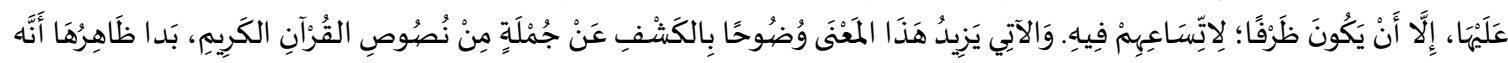

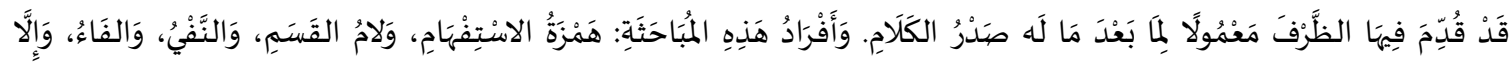
الاسنتِنْنَائِيَّة.

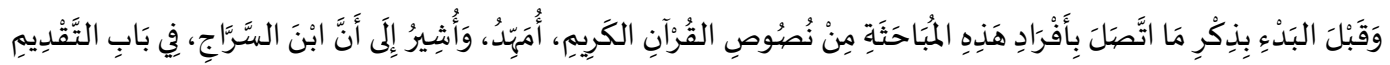

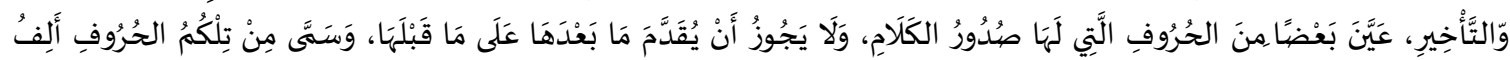

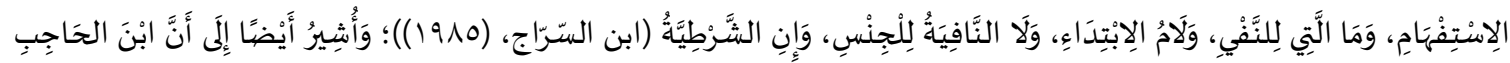

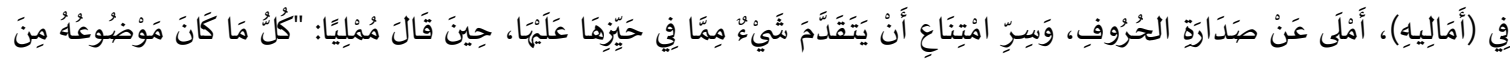




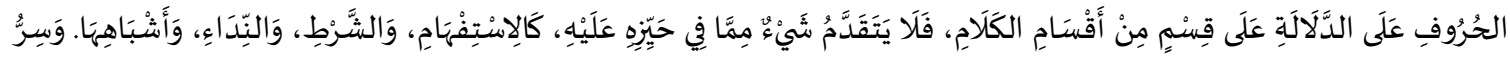

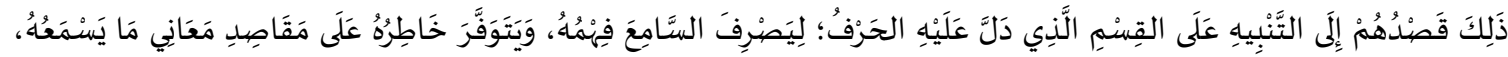

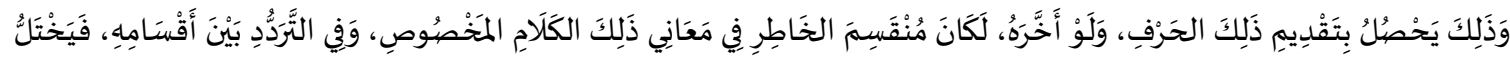

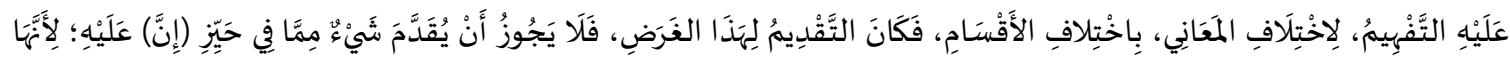

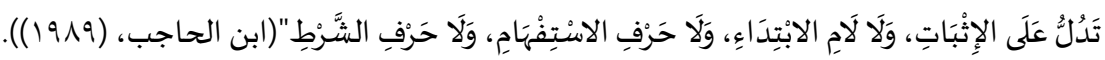

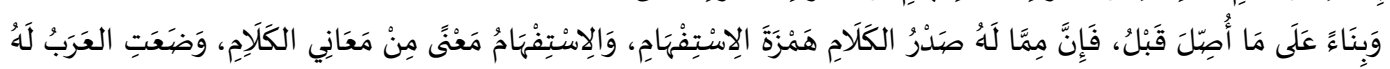

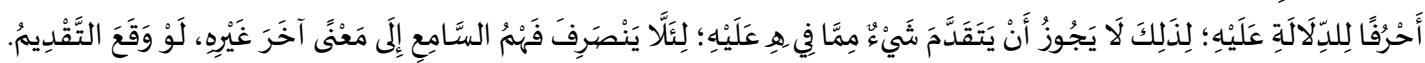

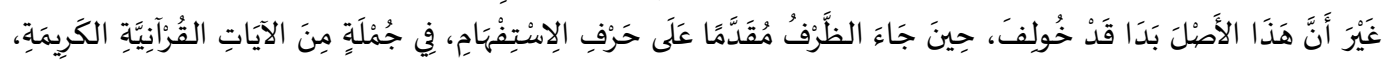

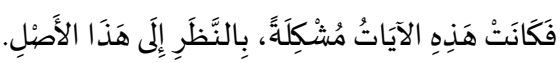

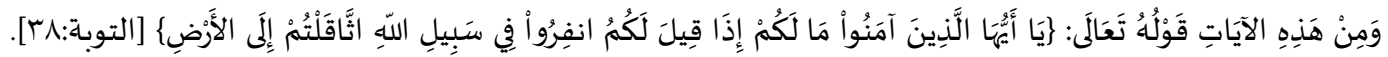

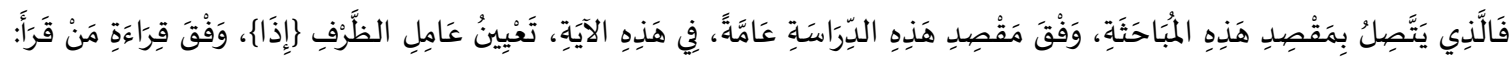

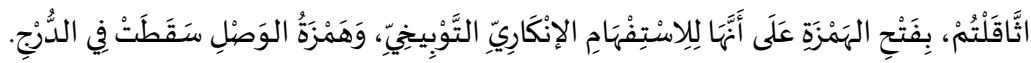

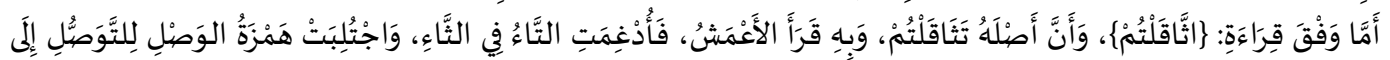

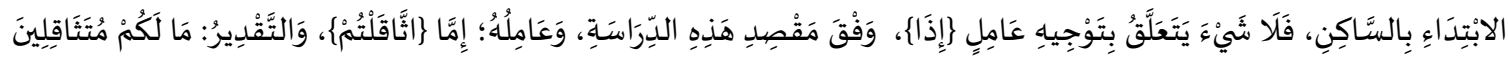

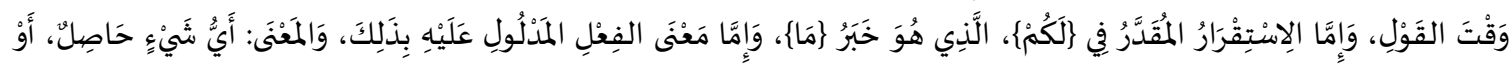

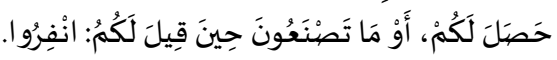

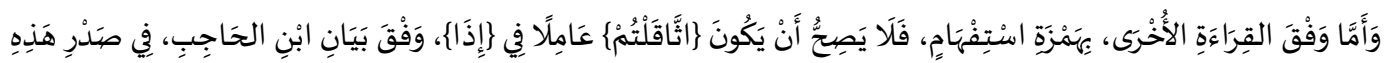

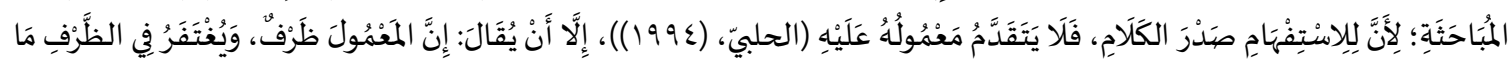

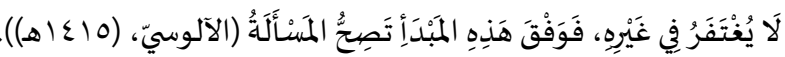

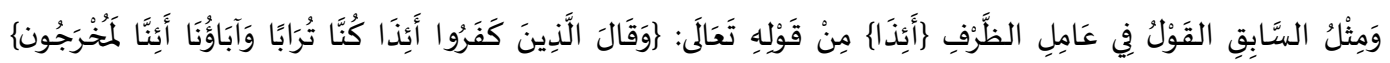

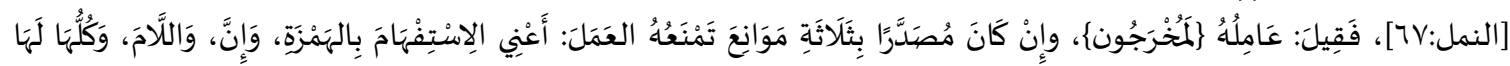

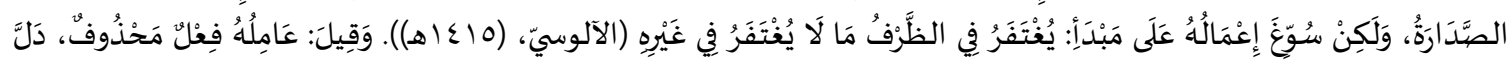

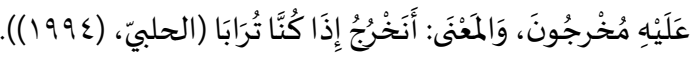

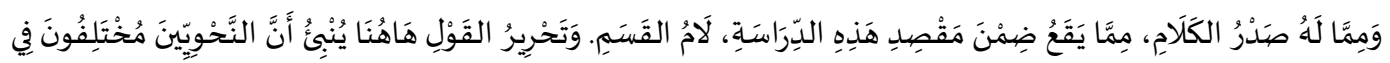

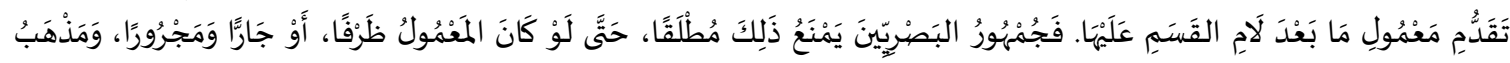

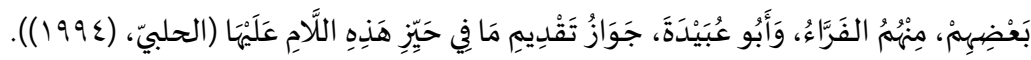

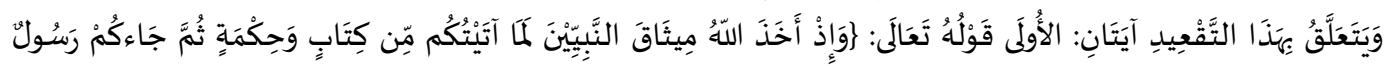

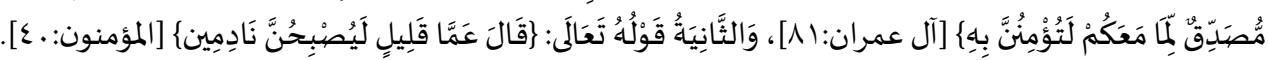

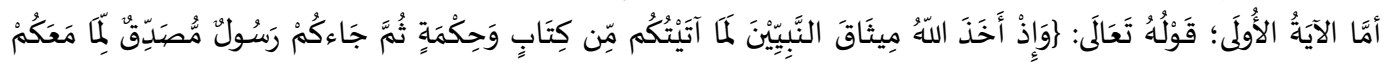

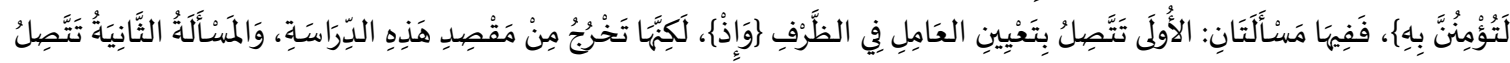

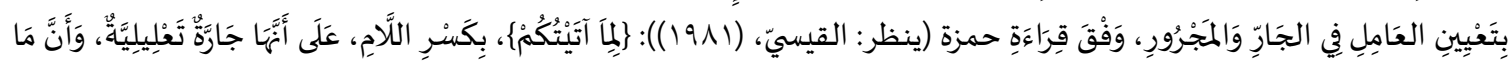

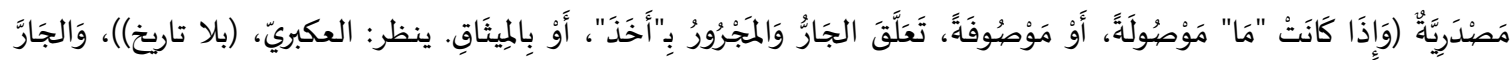

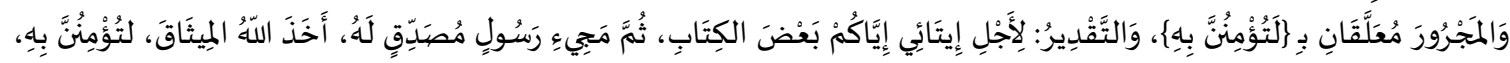

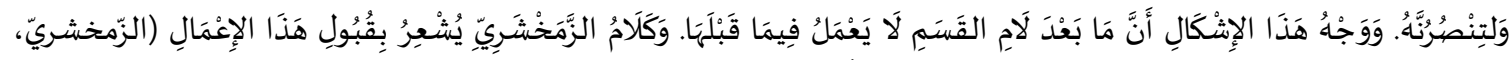

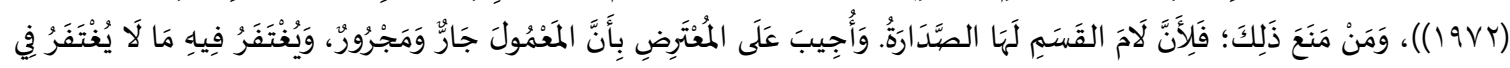

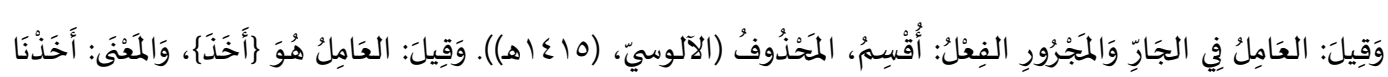
غَيْرِه.

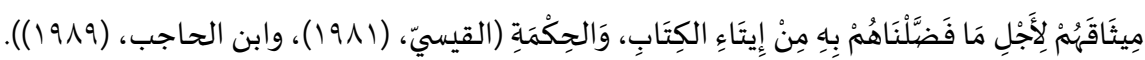

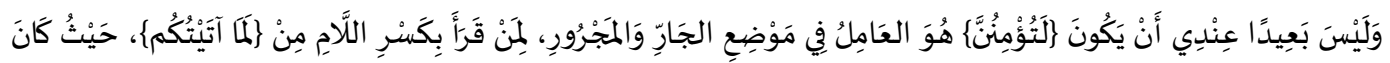

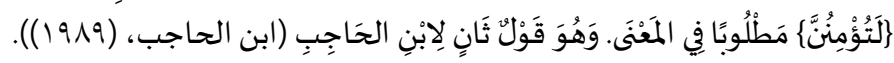




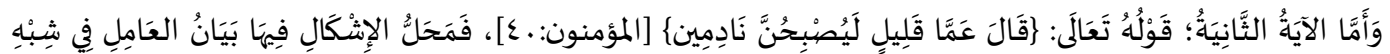

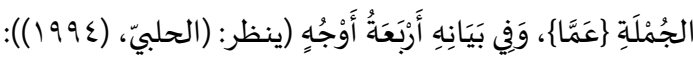

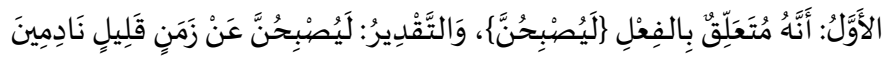

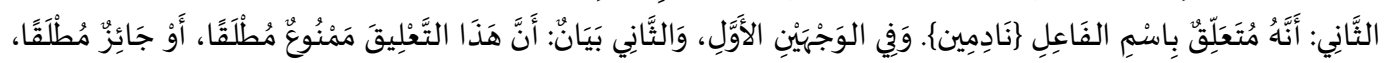

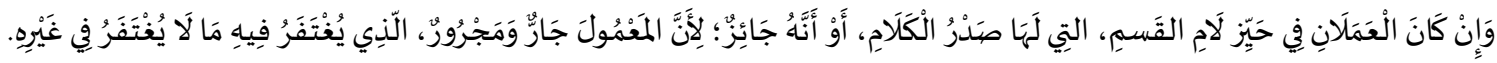

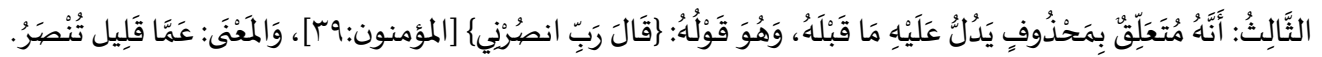

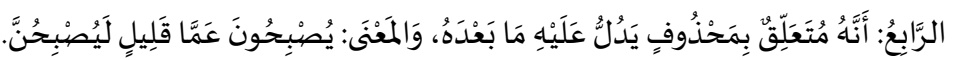

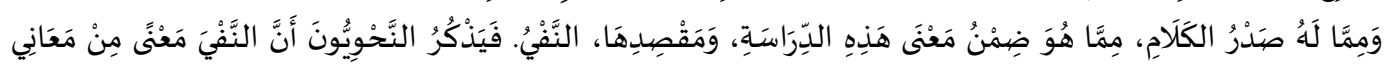

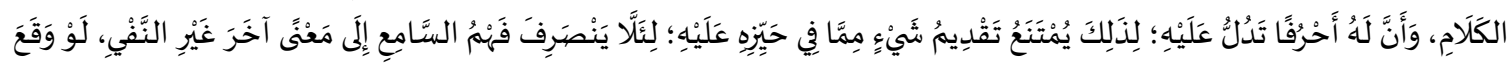

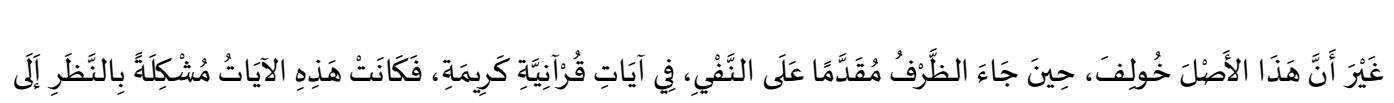

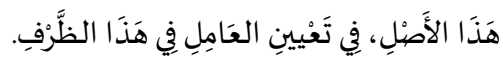

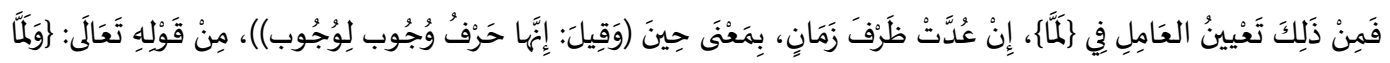

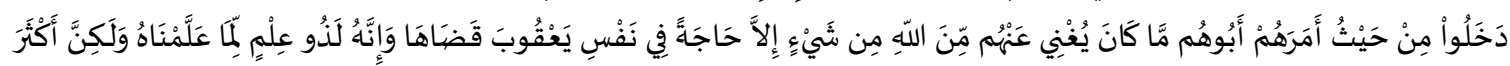

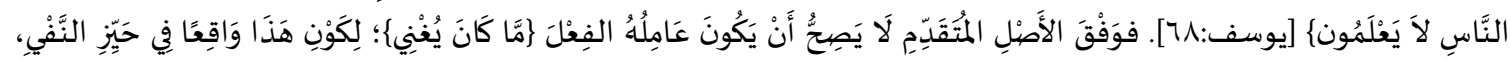

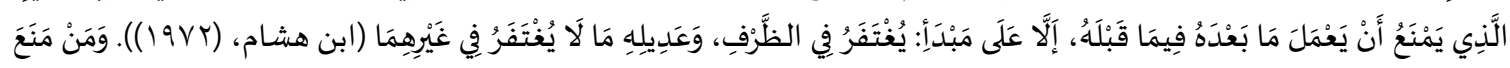

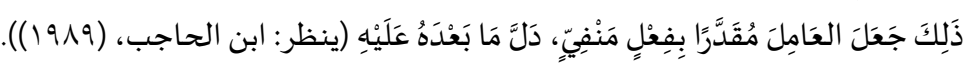

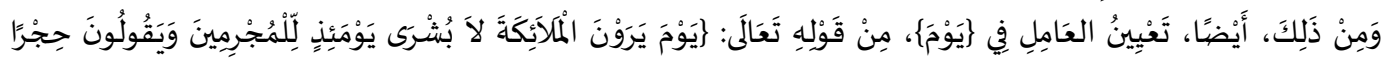

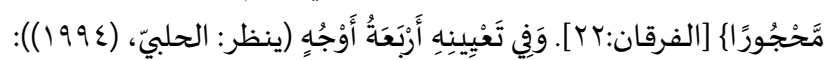

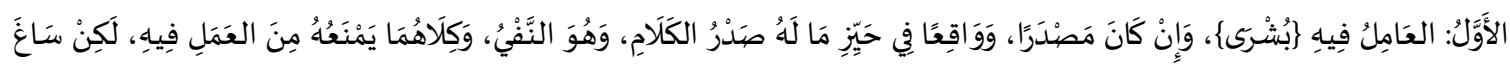

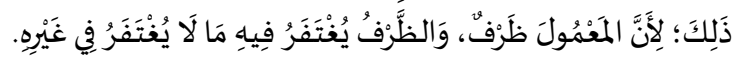

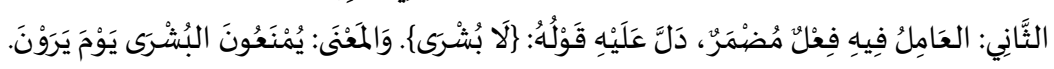

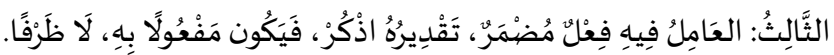

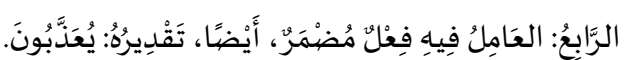

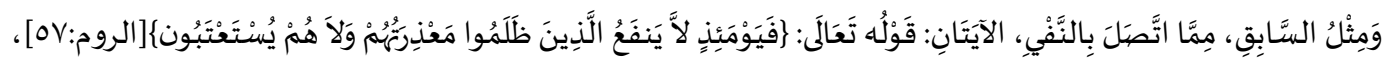

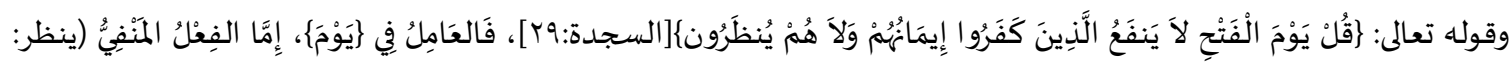

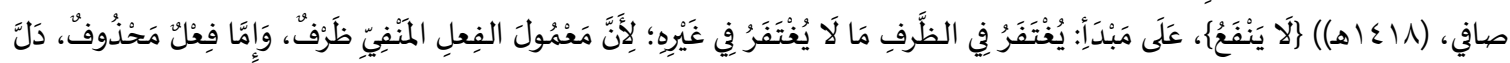

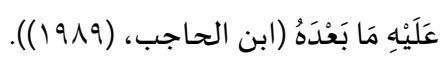

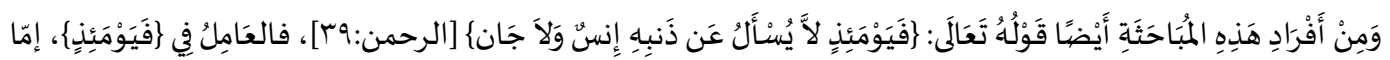

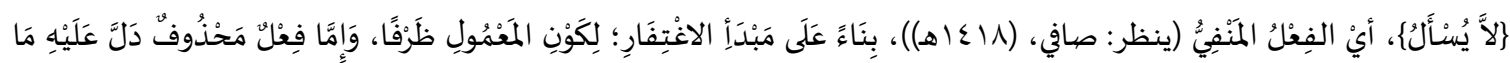

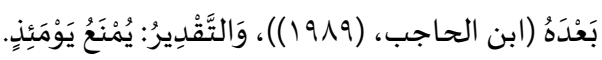

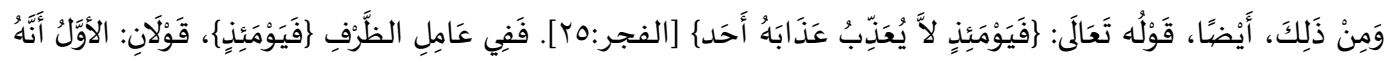

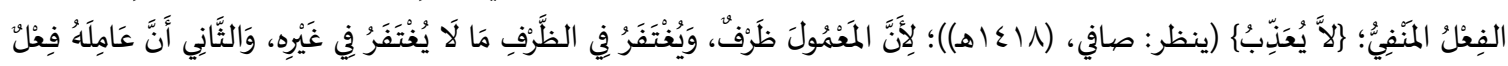

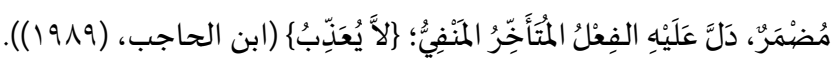

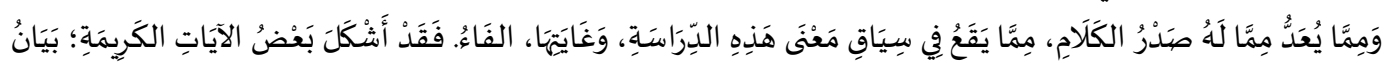

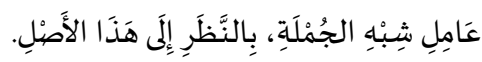

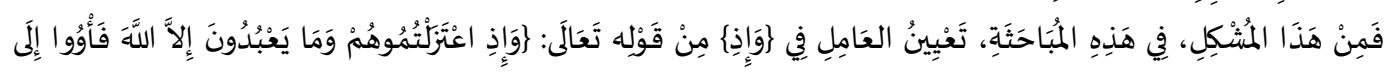

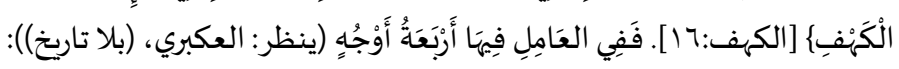

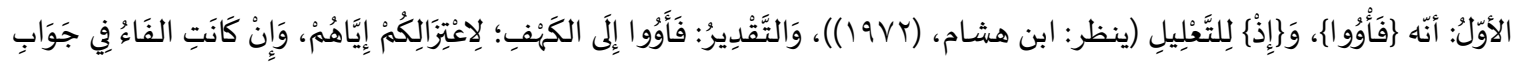

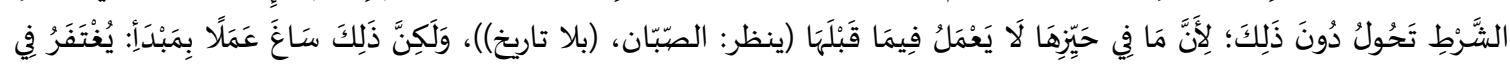

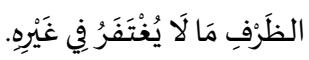




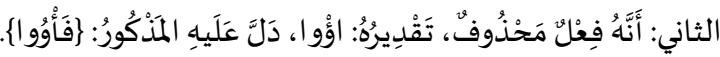

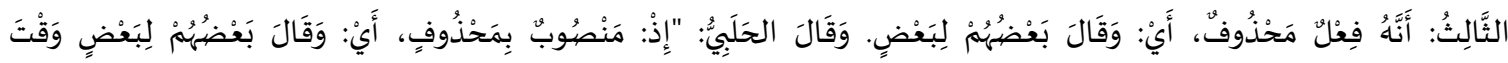

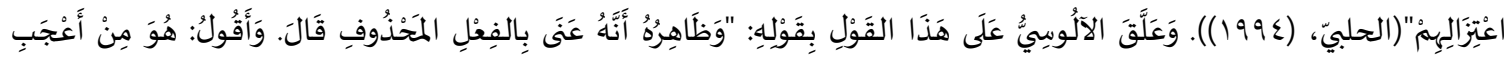

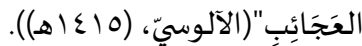

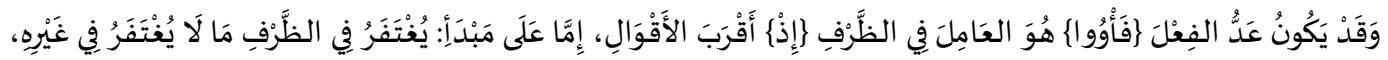

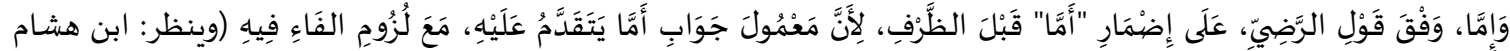

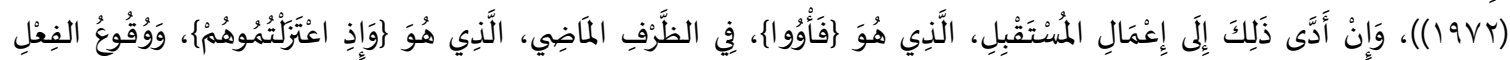

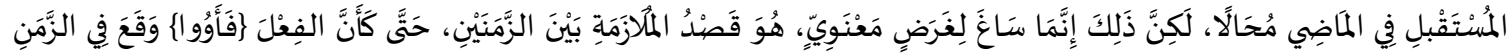

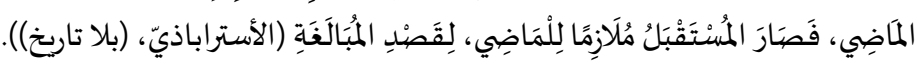

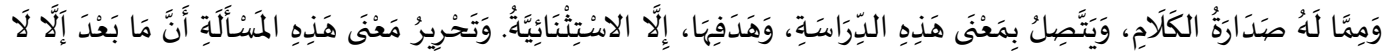

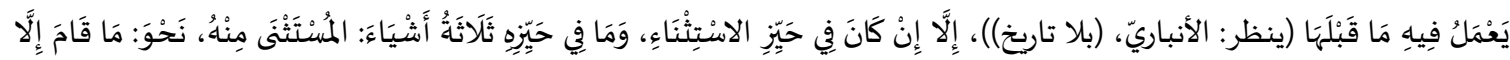

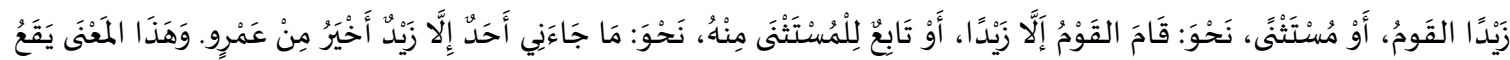

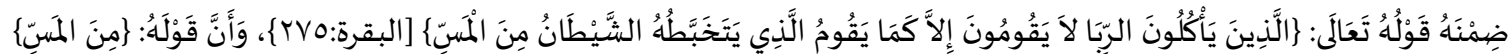

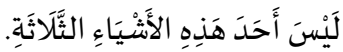

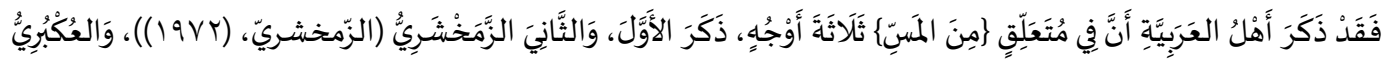

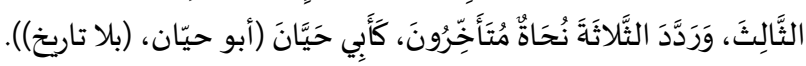

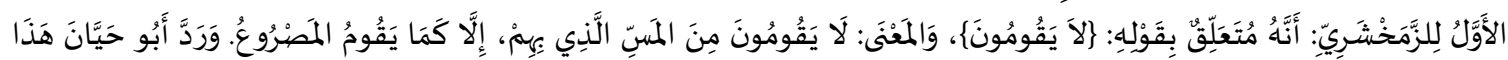

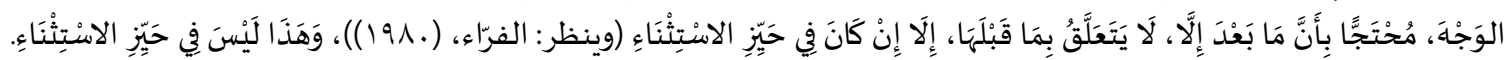

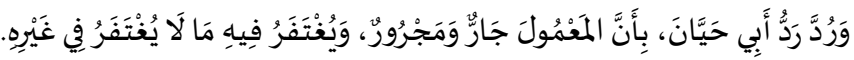

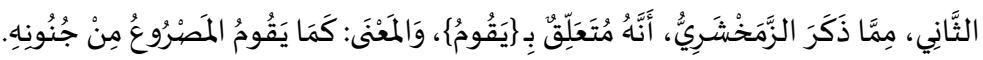

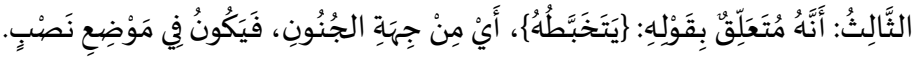

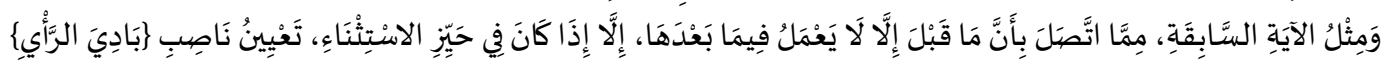

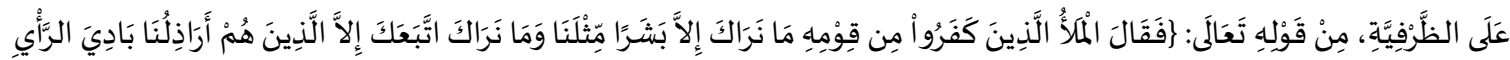

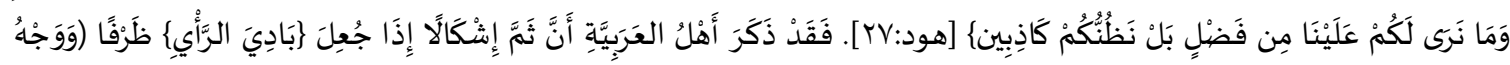

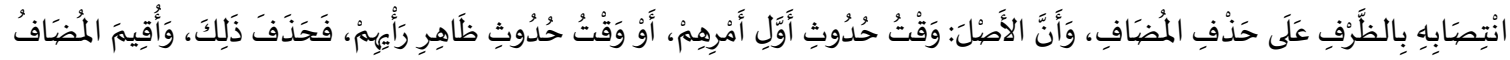

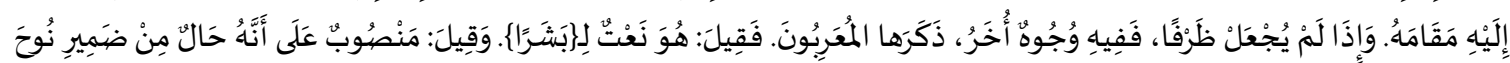

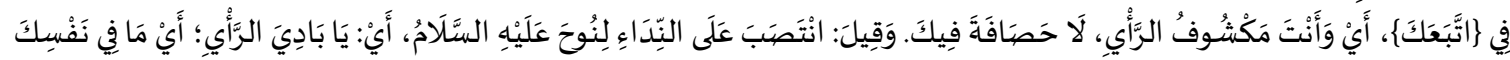

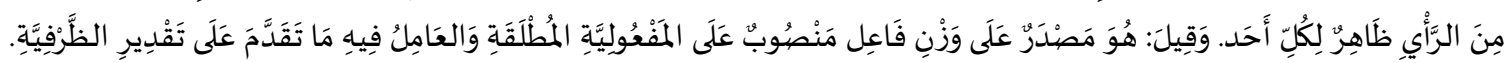

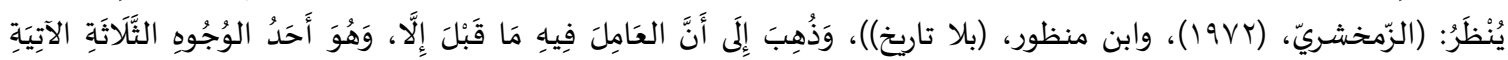

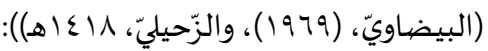

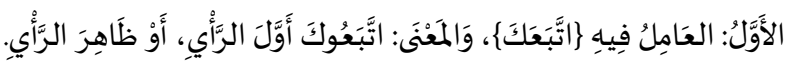

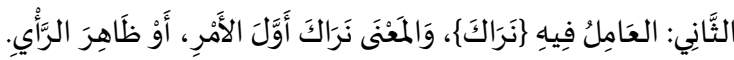

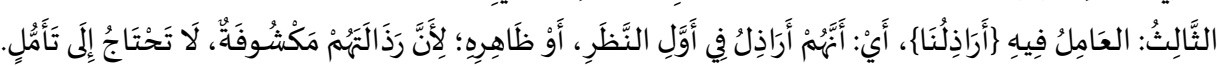

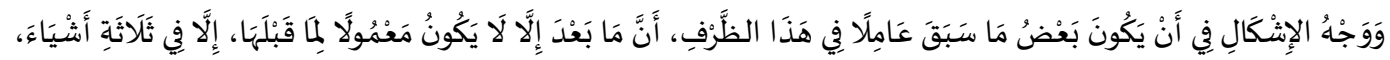

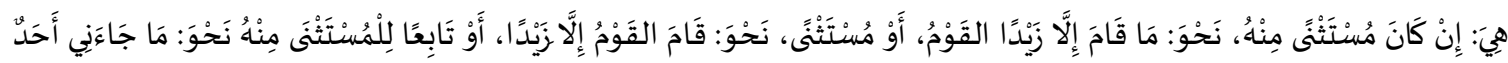

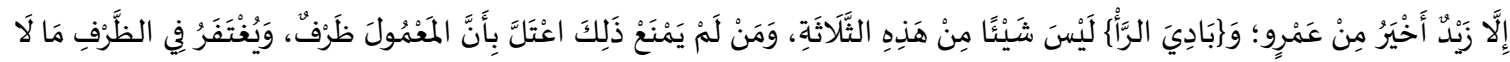

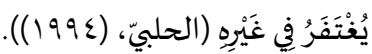

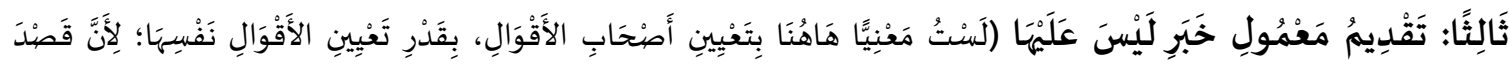

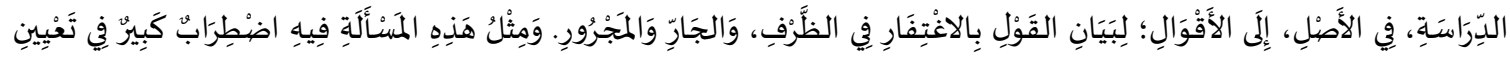

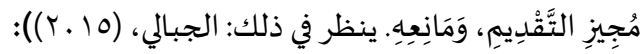




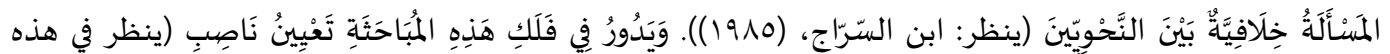

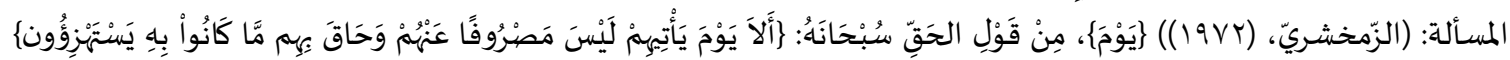

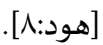

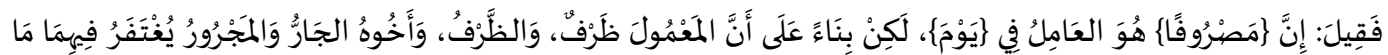

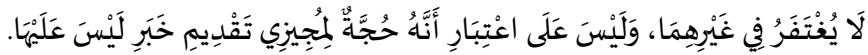

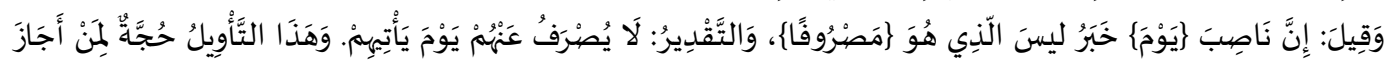

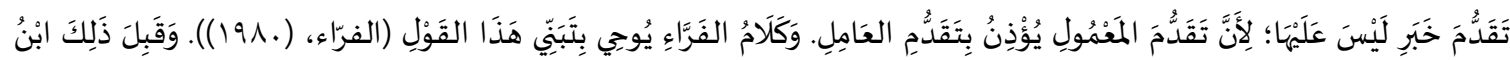

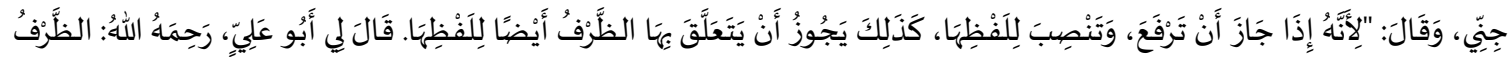

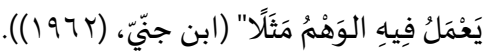

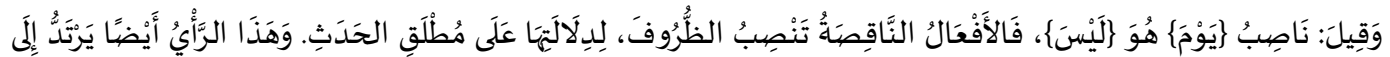

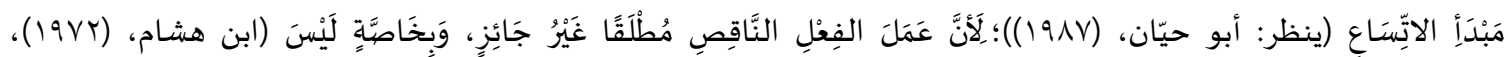

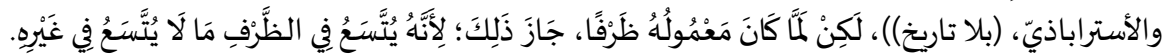

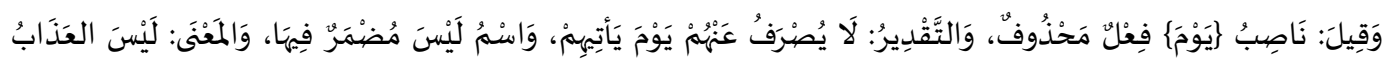
مَصْنْرففًا.

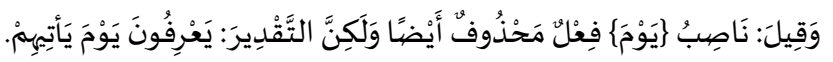

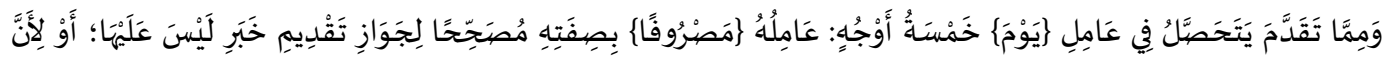

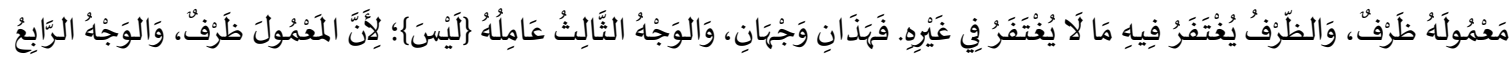

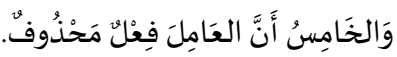

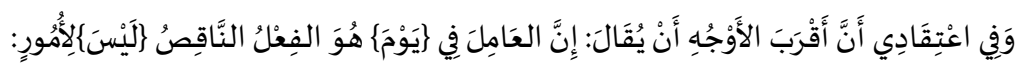

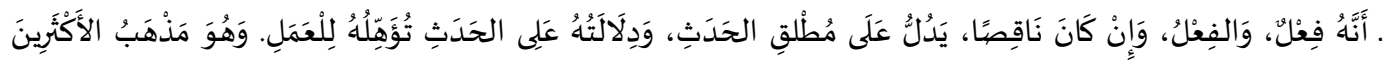

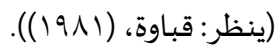

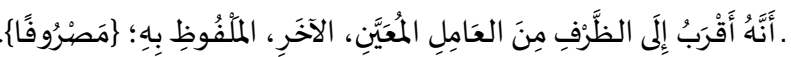

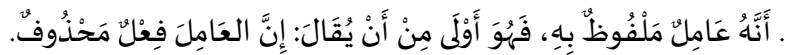

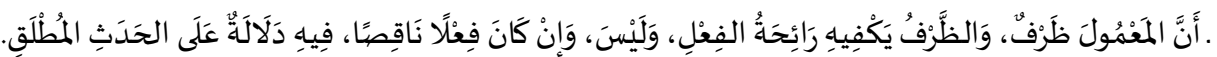

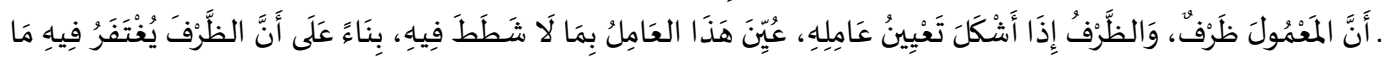
لَا يُغْتَفَرُ فِي غَيْرِه.

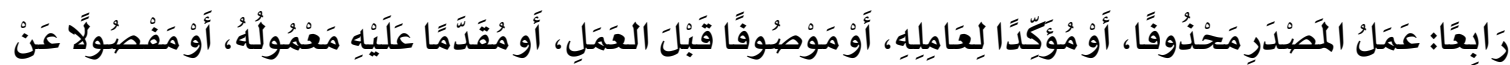

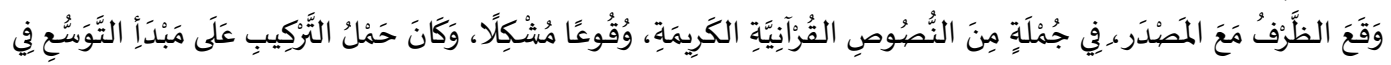

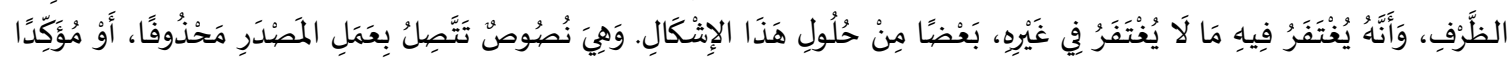

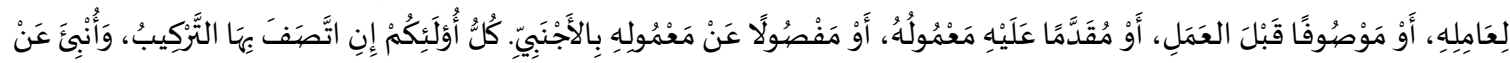

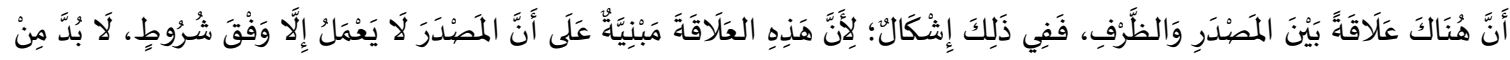

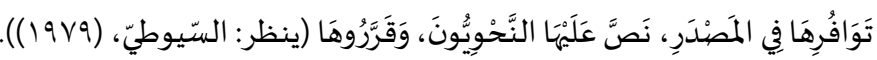

عَمَلُ المَصْنَدَرِحَحْدُوفُا:

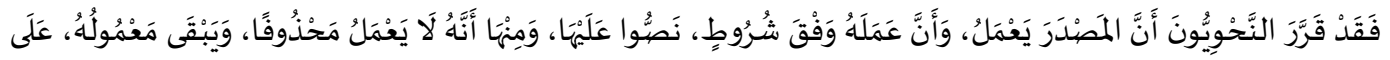

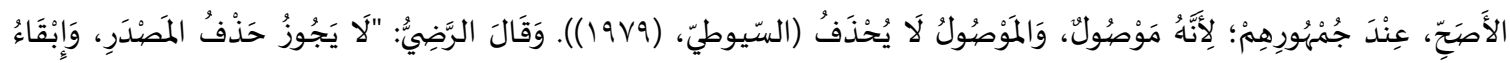

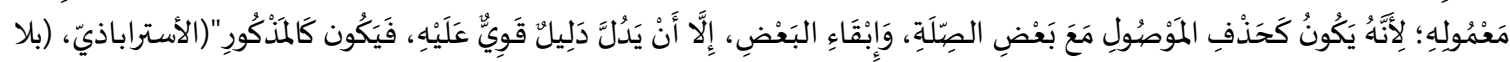




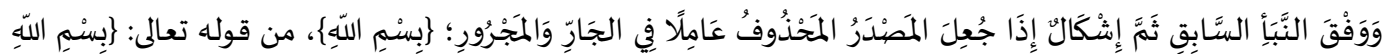

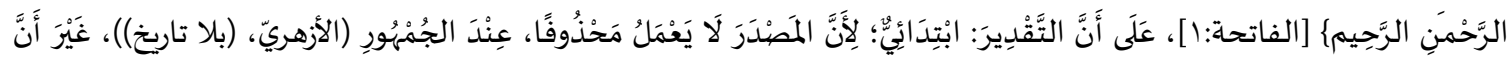

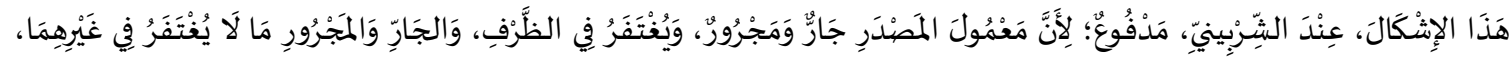

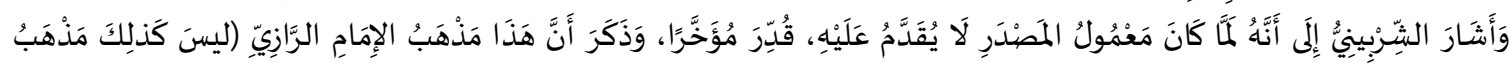

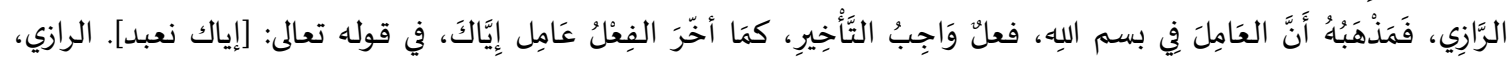

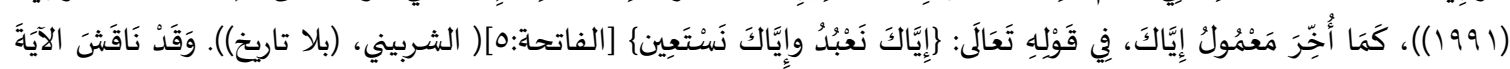

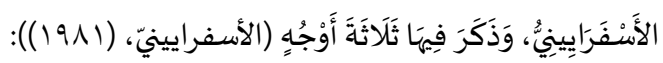

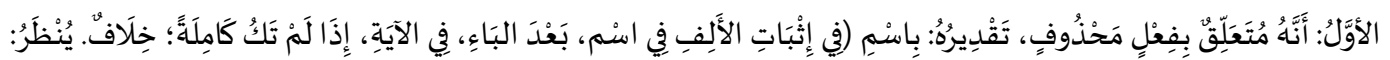

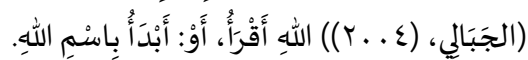

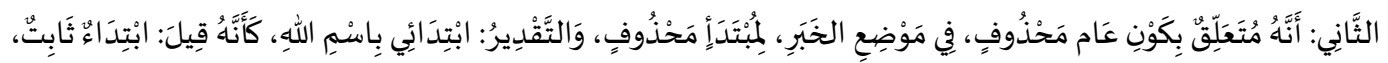

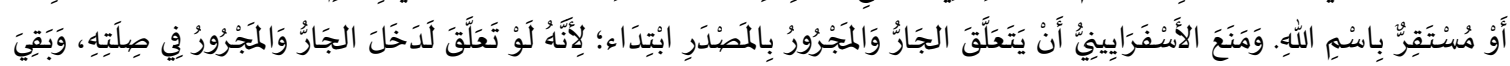

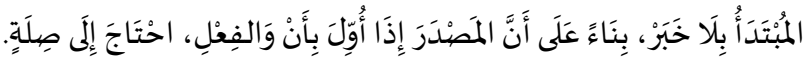

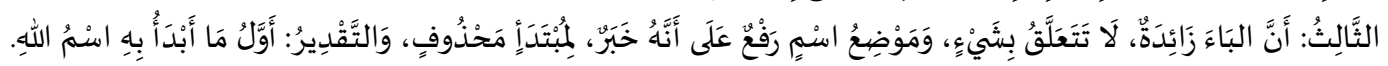

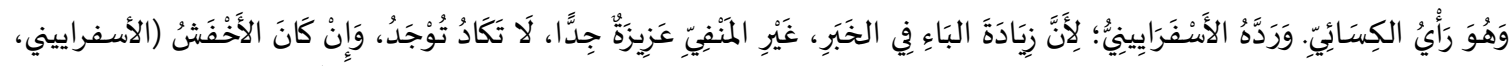

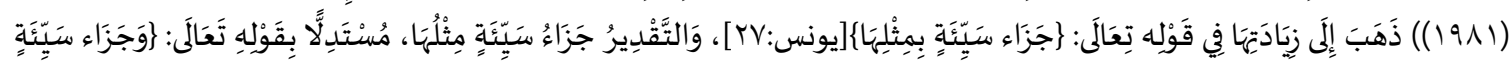

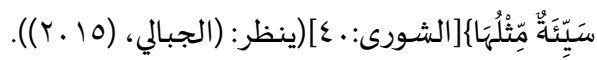

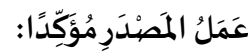

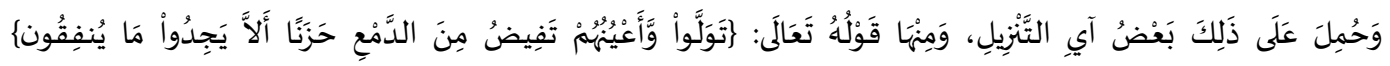

[التوبة:ra]

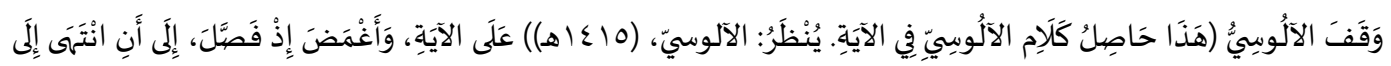

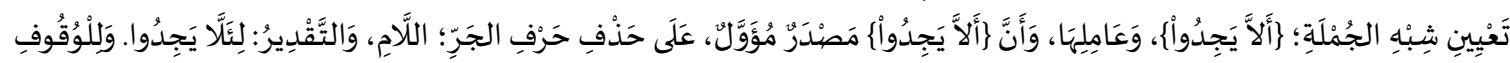

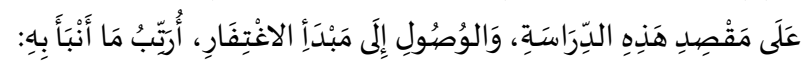

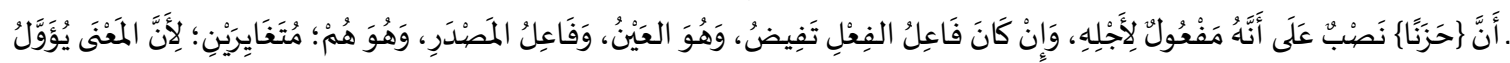

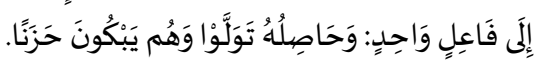

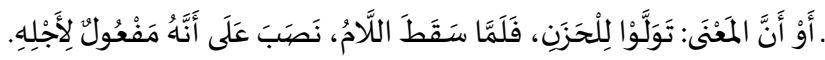

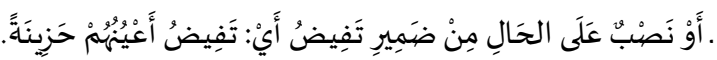

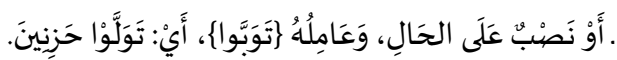

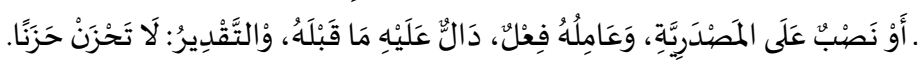

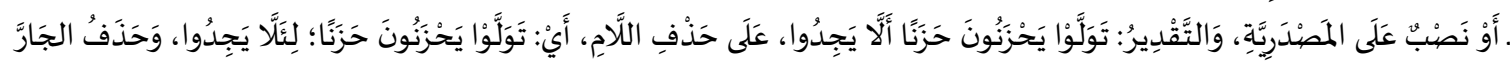
فِي مِثْلِ ذَلِكَ مُطَُّردِ.

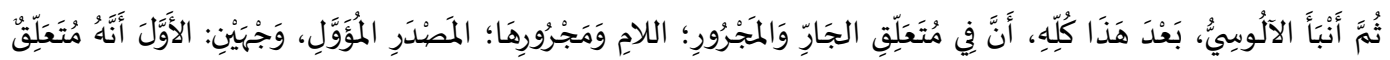

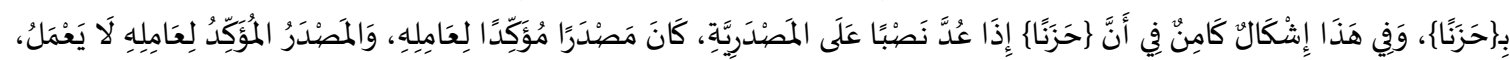

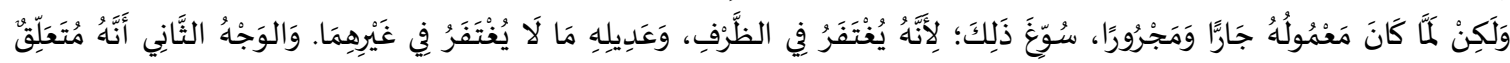

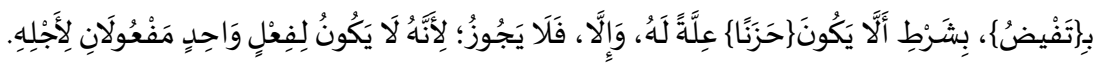

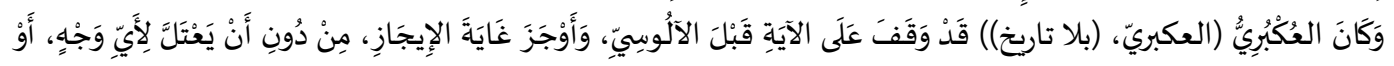

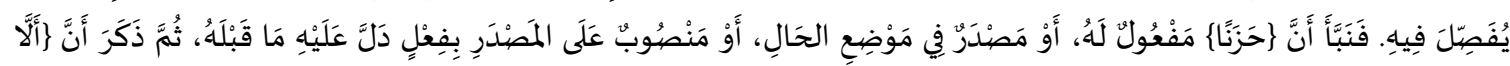

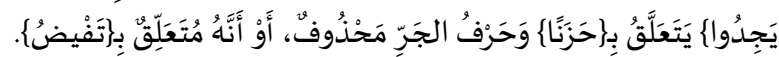

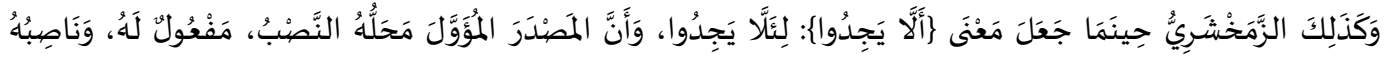

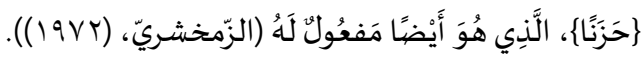




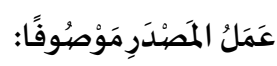

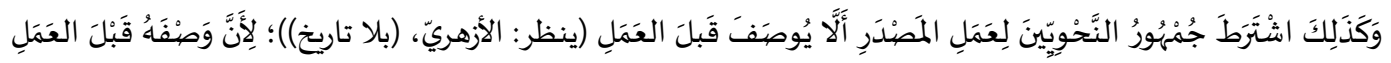

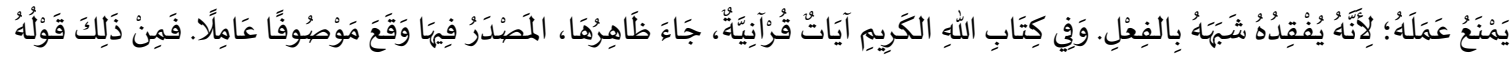

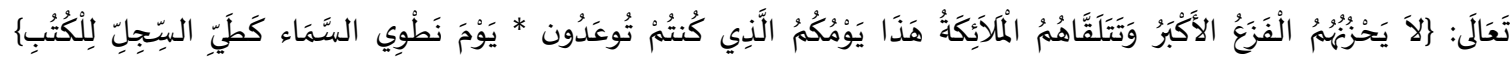

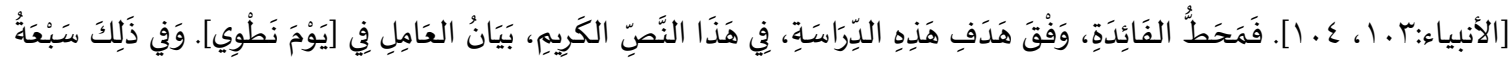

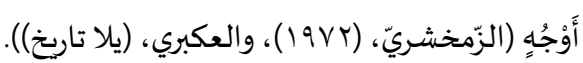

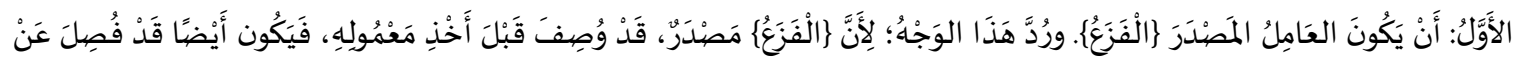

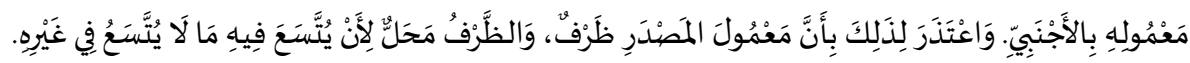

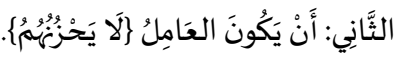

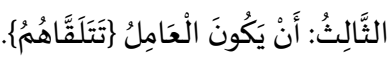

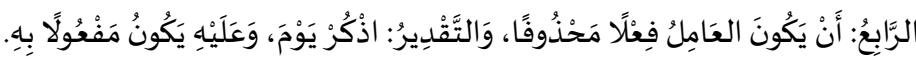

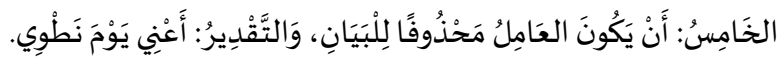

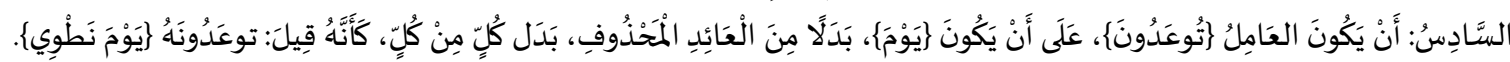

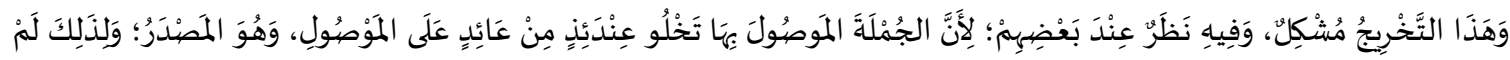

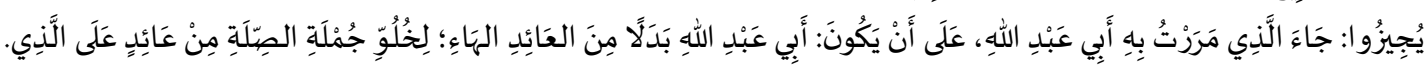

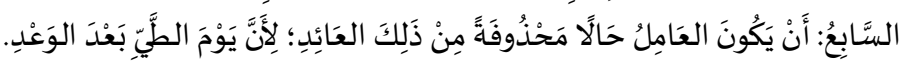

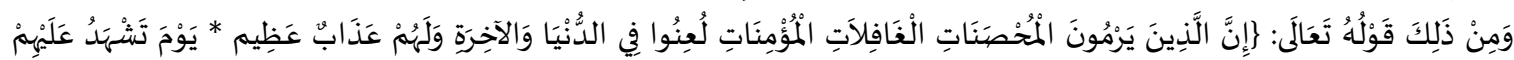

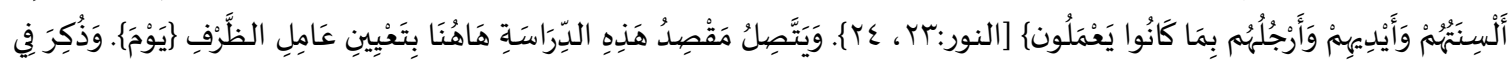

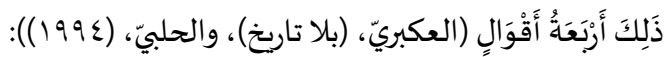

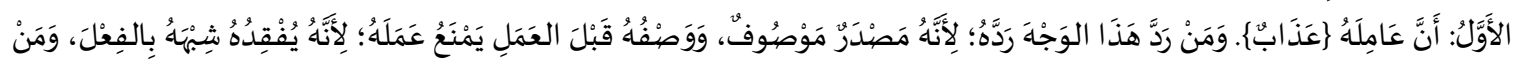

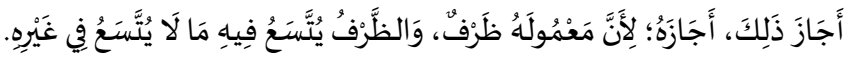

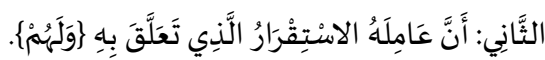

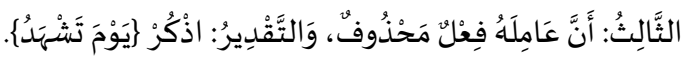

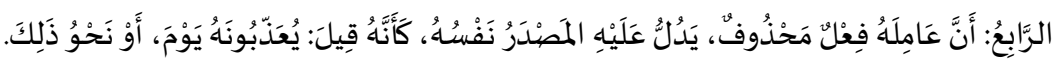

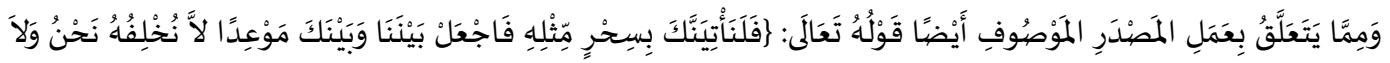

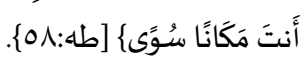

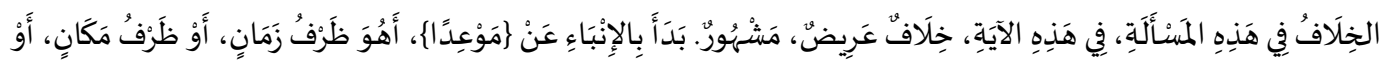

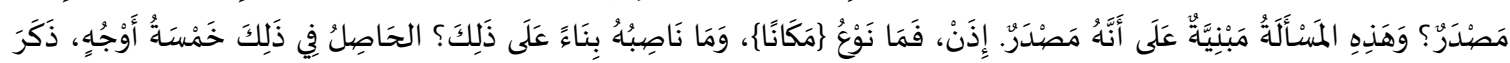

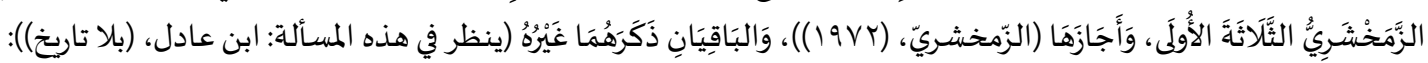

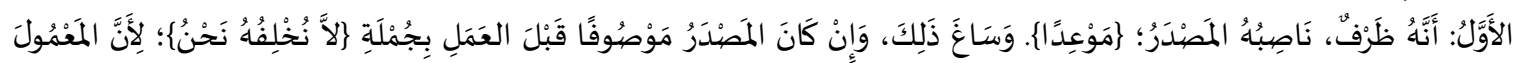

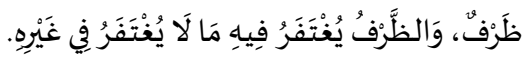

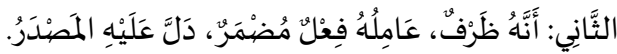

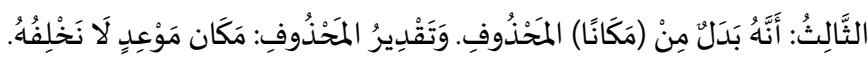

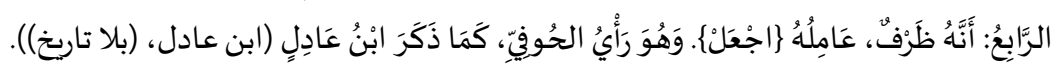

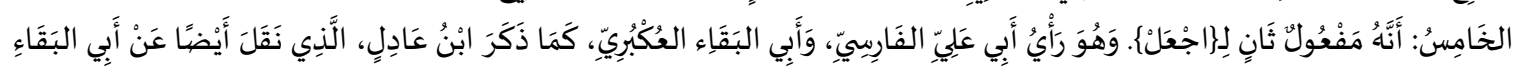

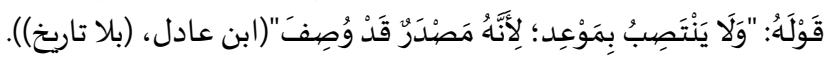

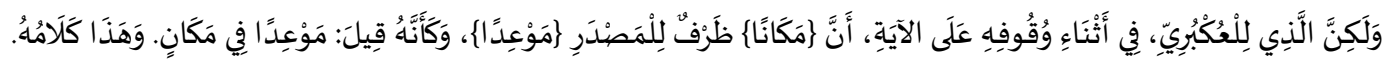

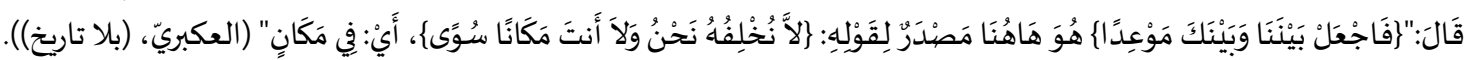

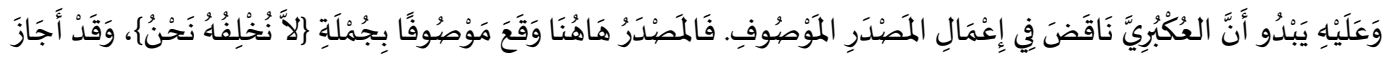

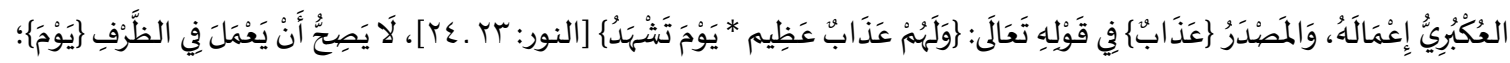

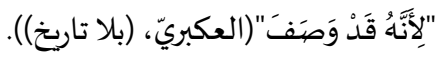




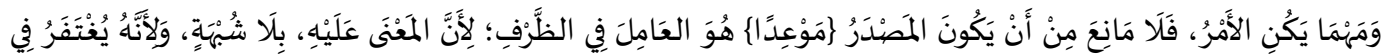

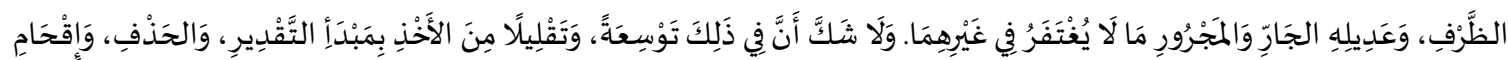
مَا لَيْسنَ مِنَ النَّصِّ فِيِهِ.

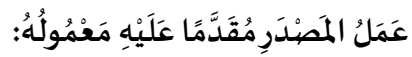

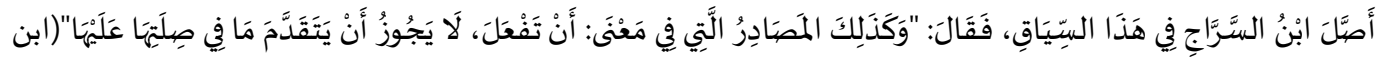

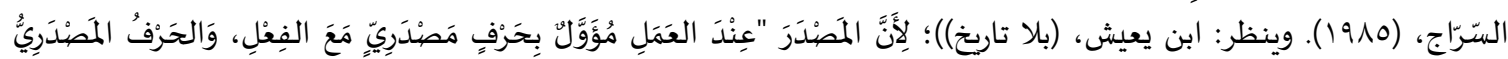

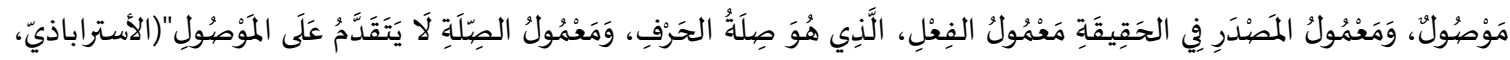

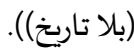

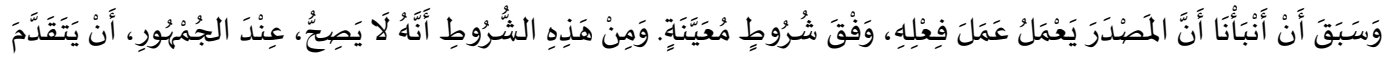

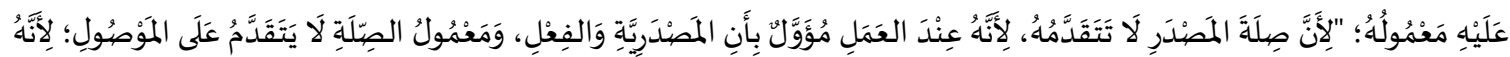

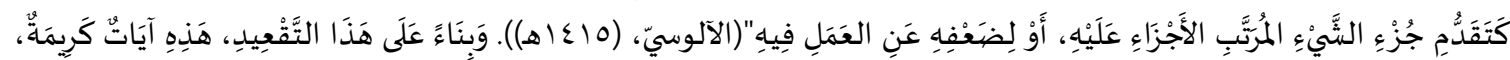

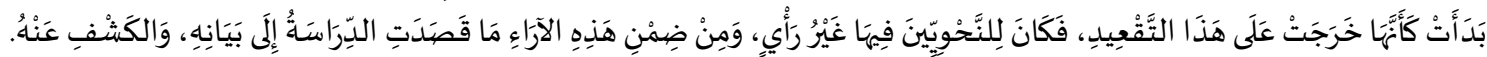

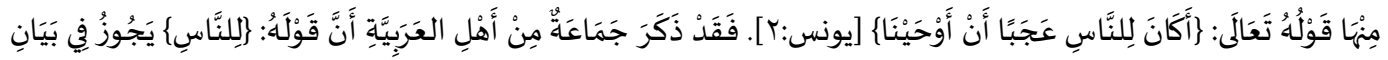

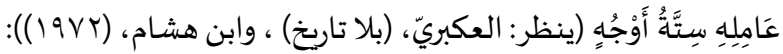

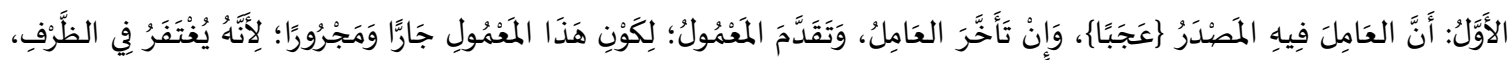

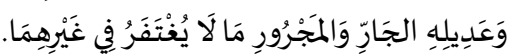

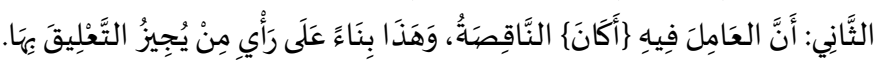

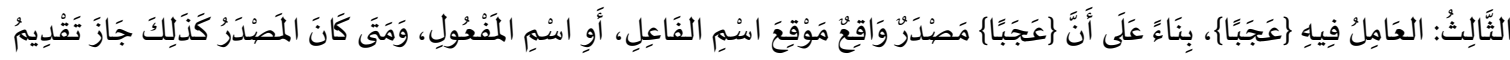
مَعْمُولِهِ عَلَيِْه.

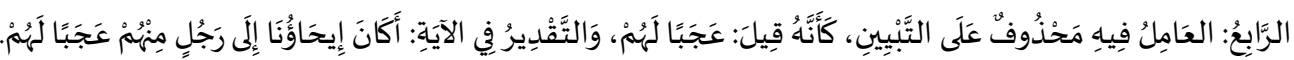

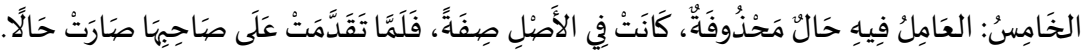

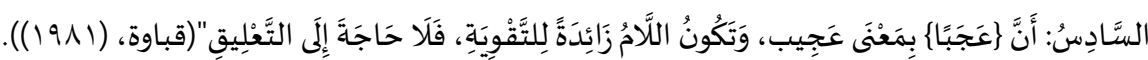

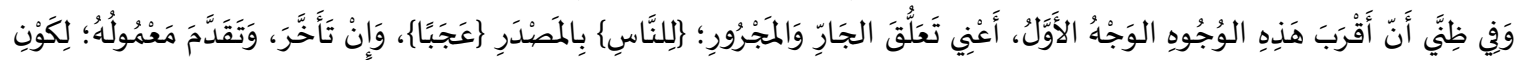

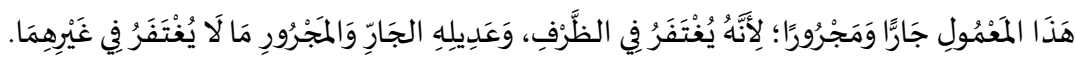

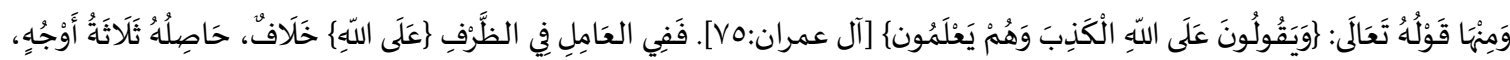

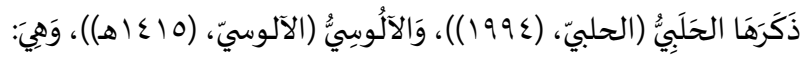

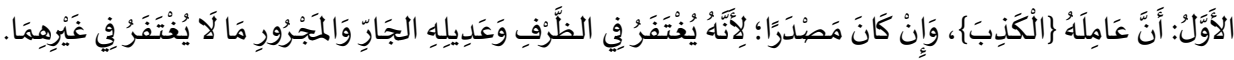

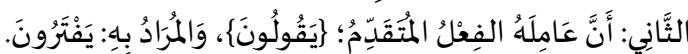

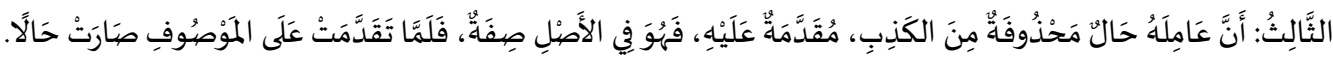

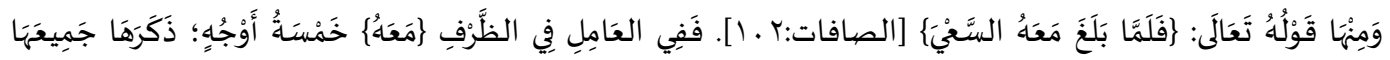

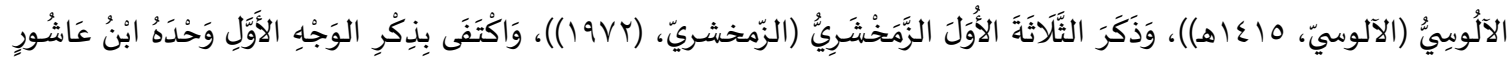

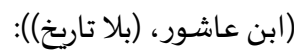

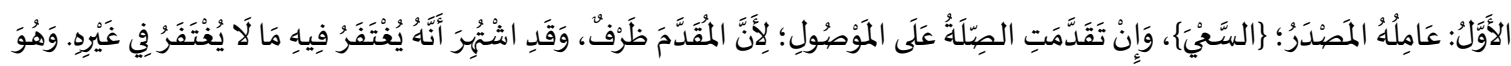

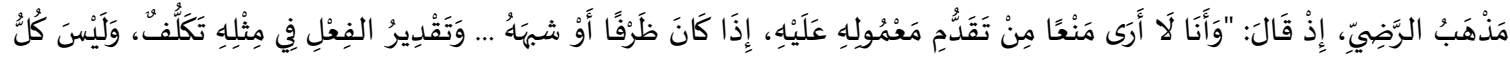

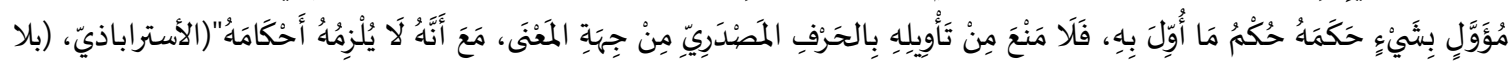

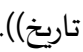

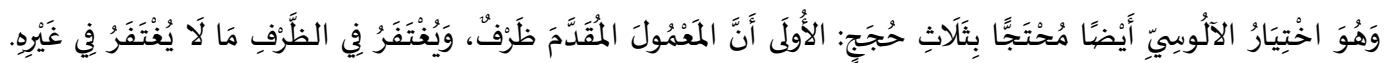

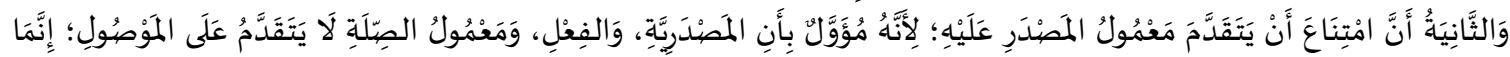

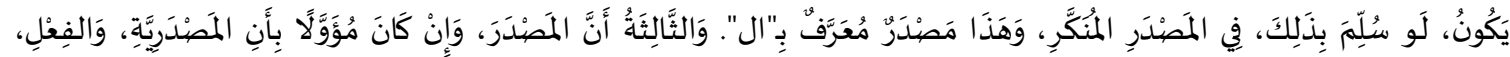

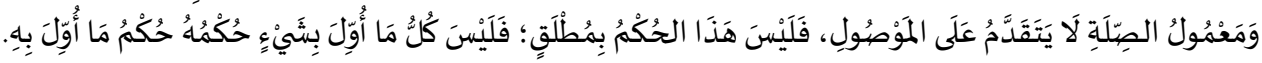




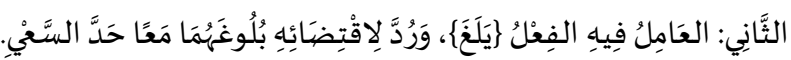

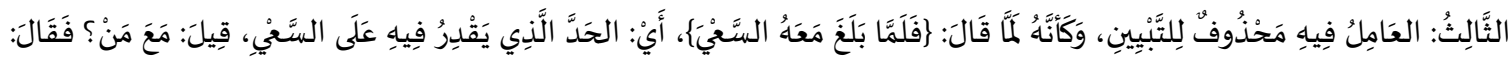

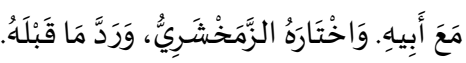

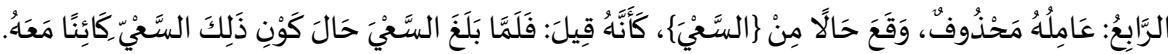

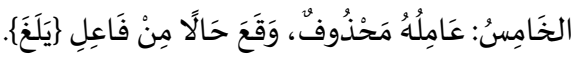

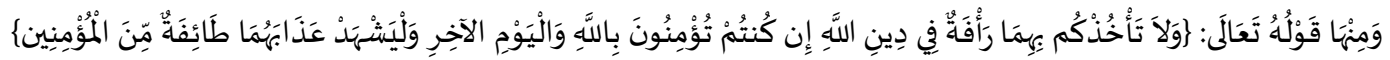

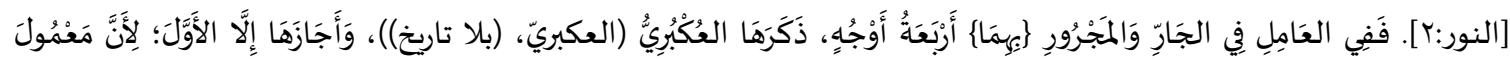

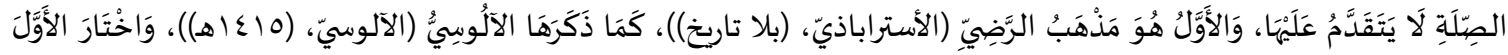

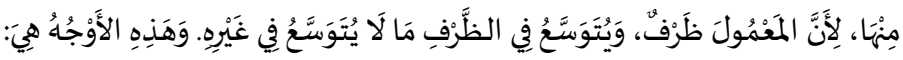

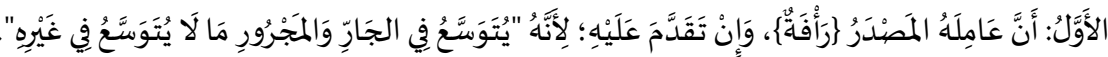

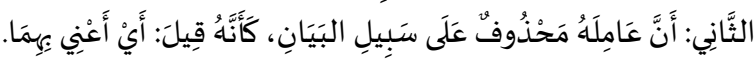

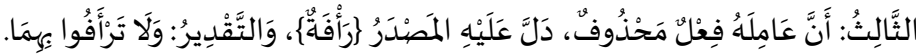

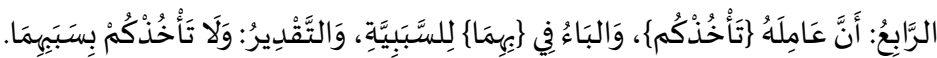

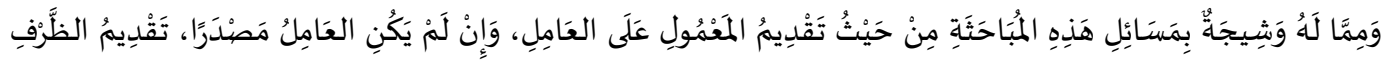

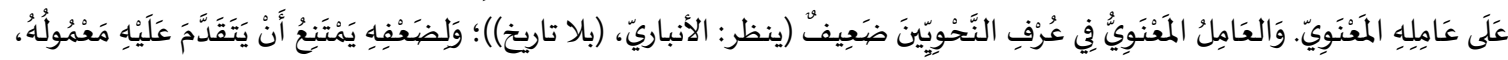

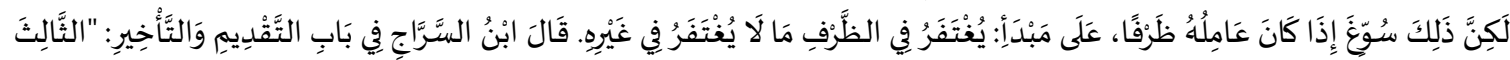

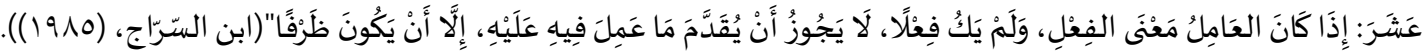

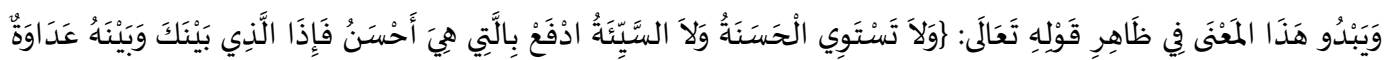

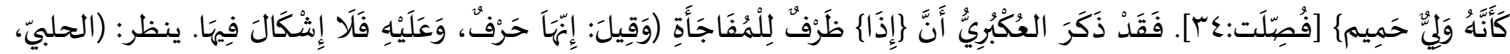

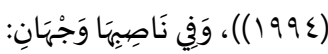

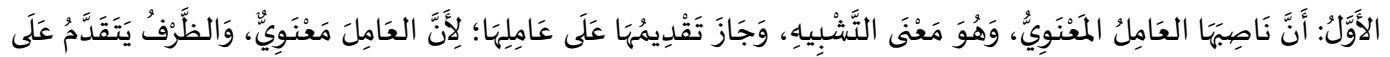

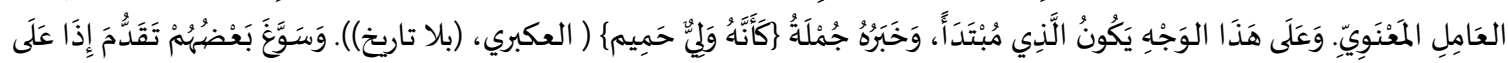

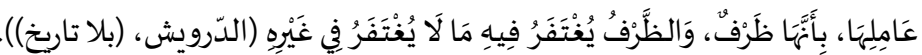

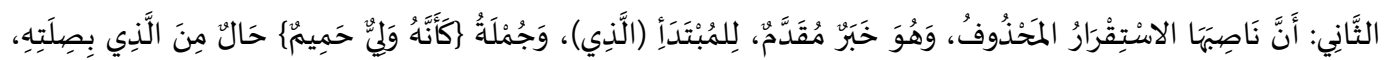

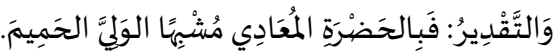

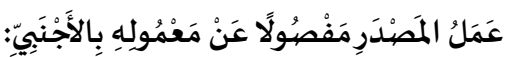

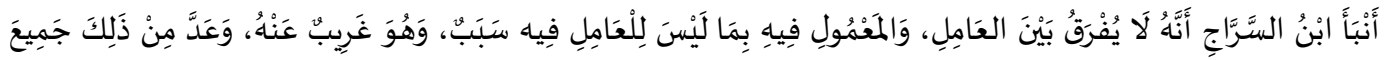

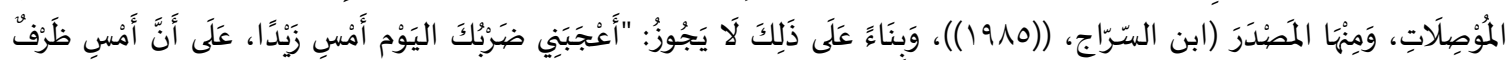

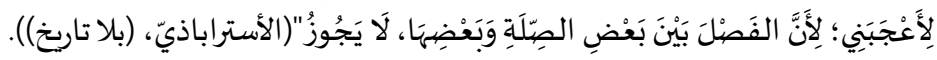

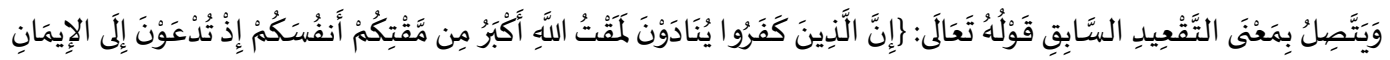

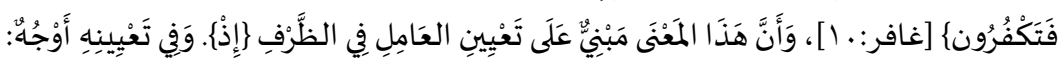

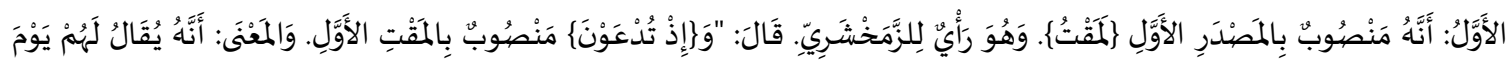

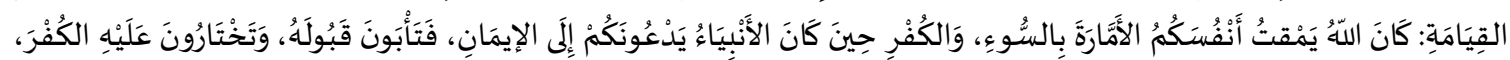

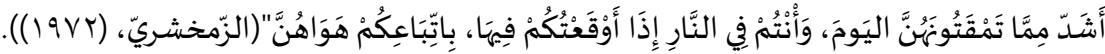

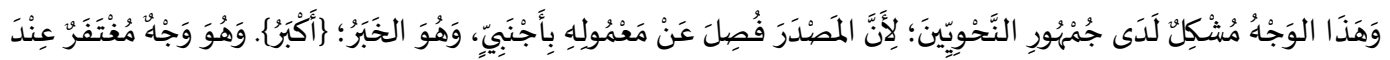

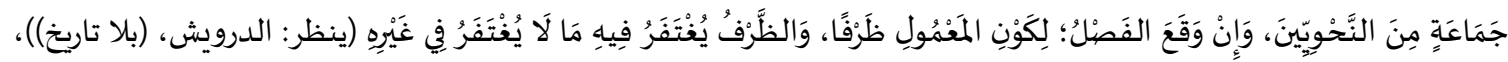

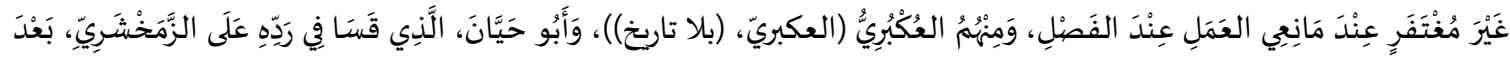

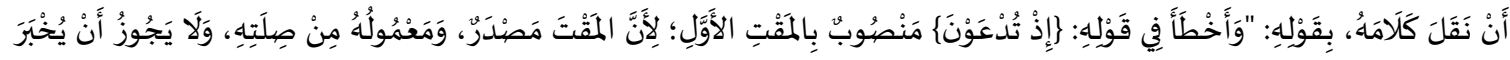

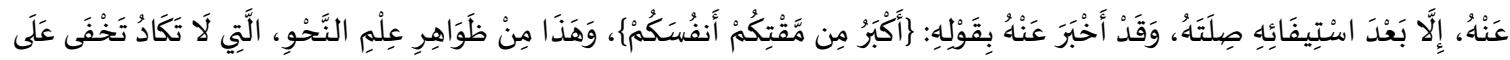

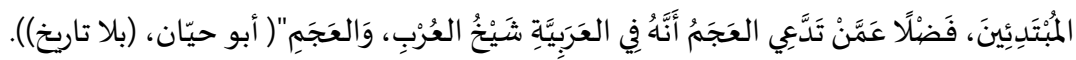




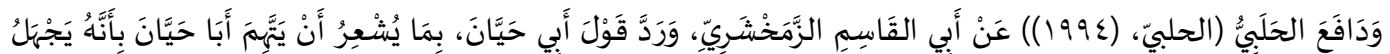

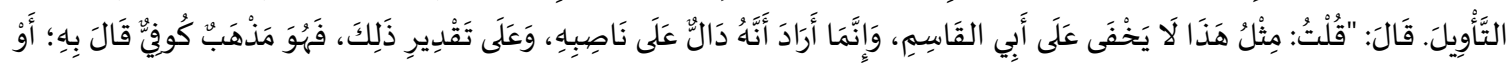

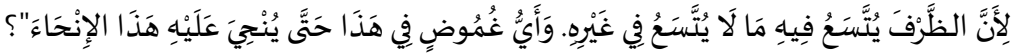

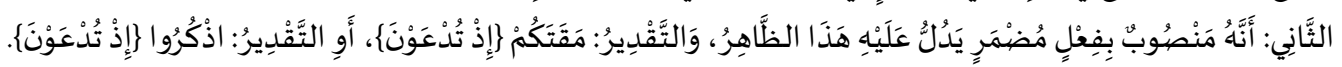

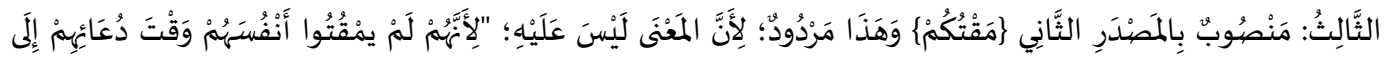

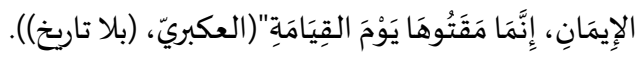

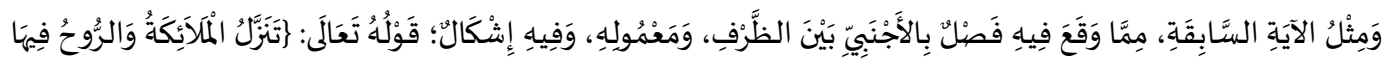

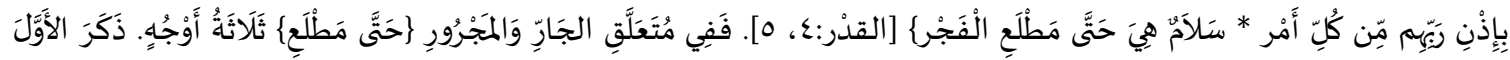

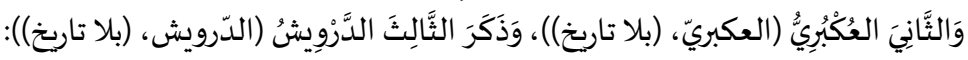

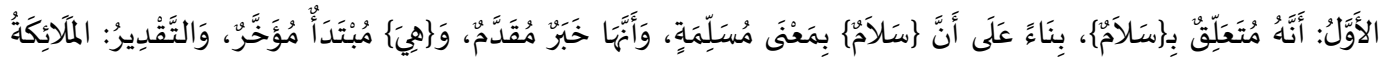

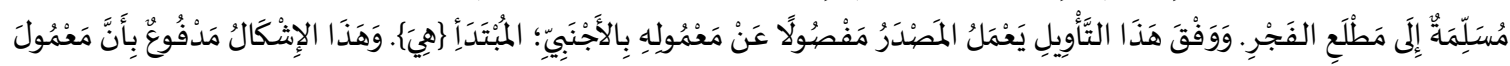

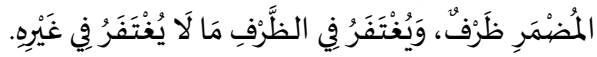

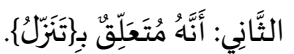

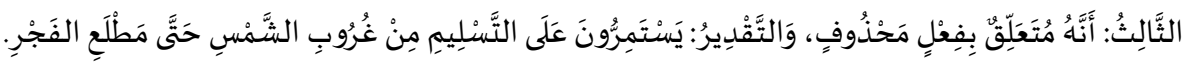

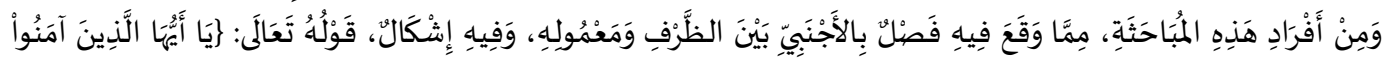

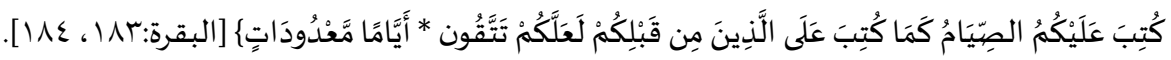

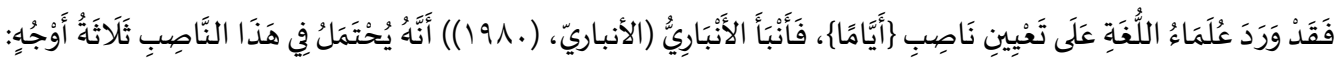

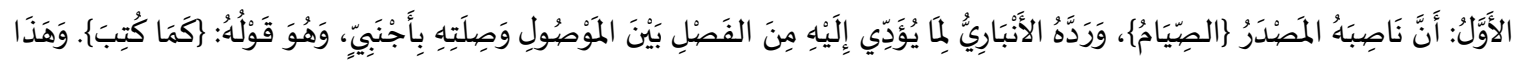

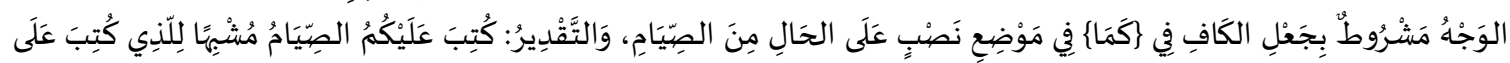

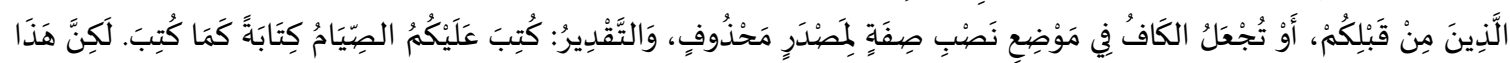

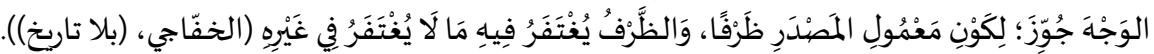

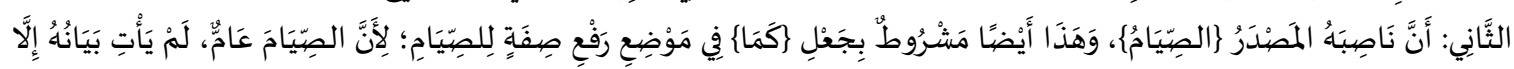

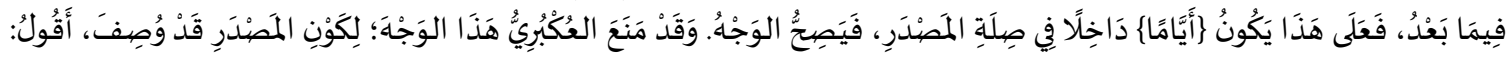

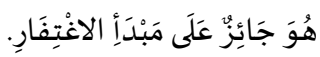

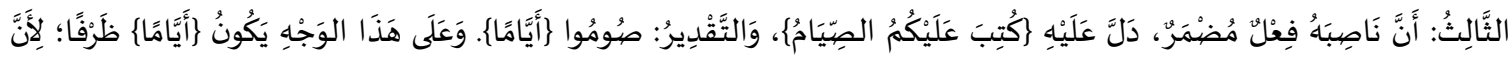

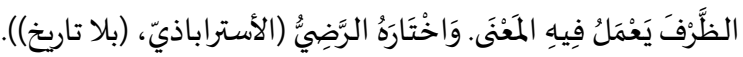

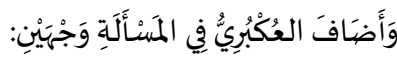

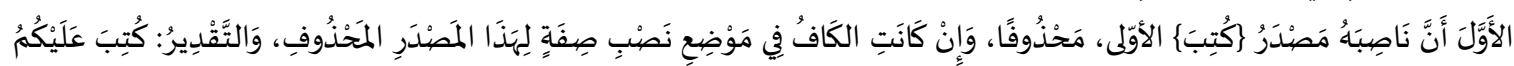

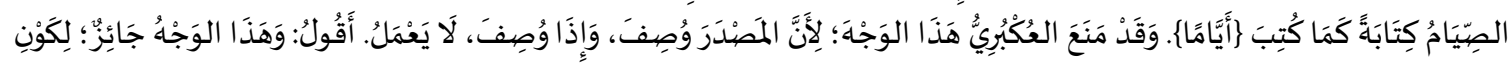

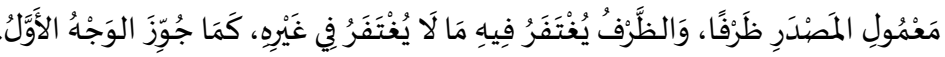

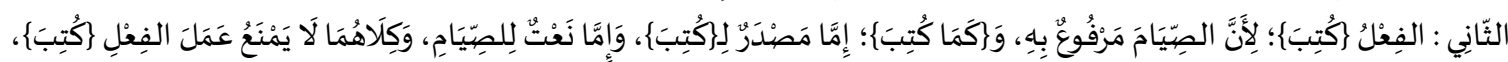

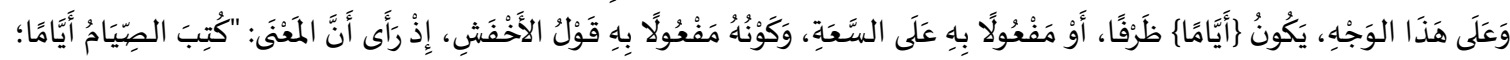

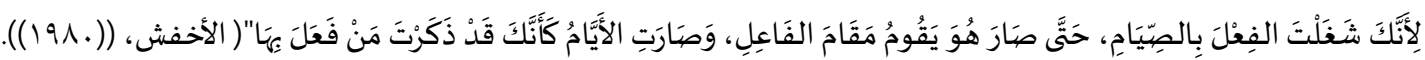

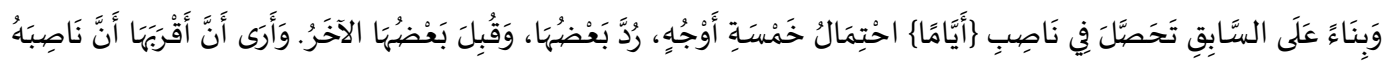

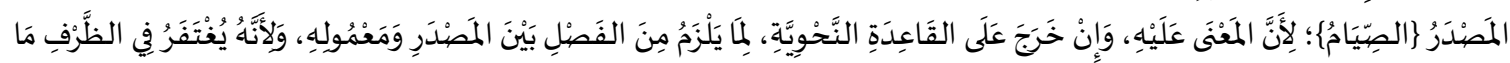

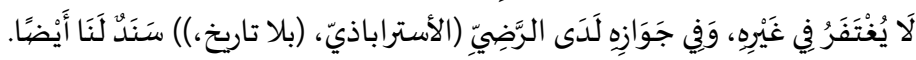

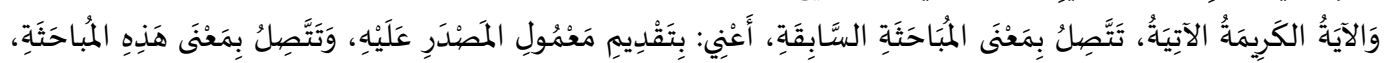

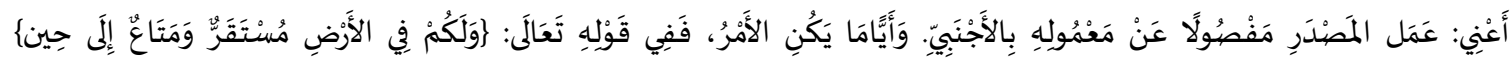

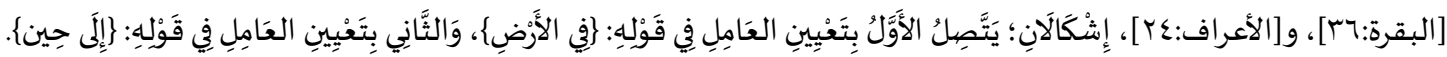

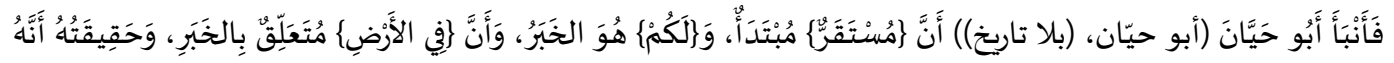

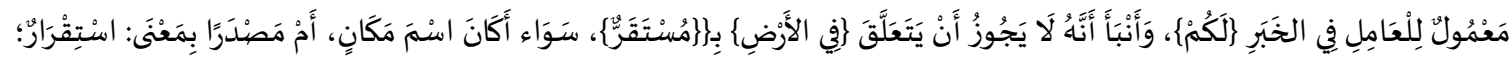




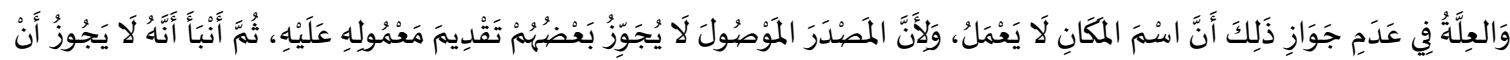

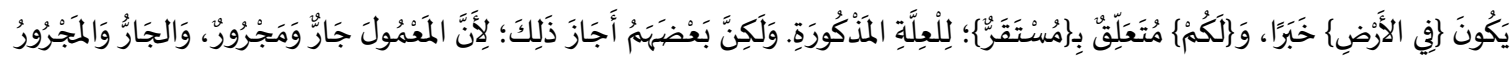

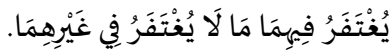

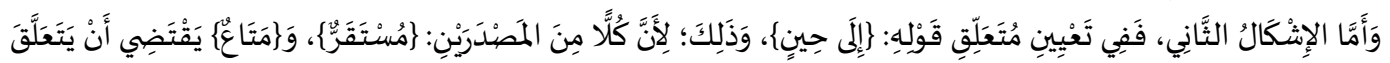

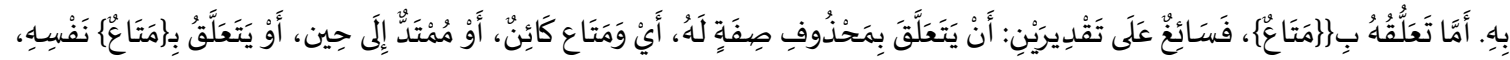

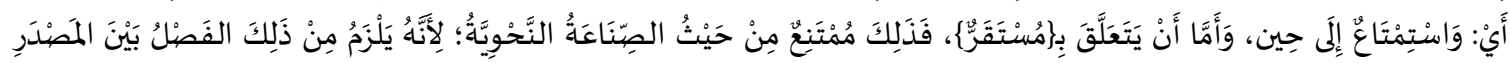

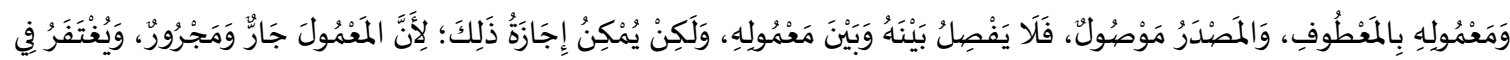

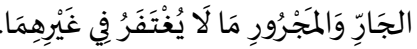

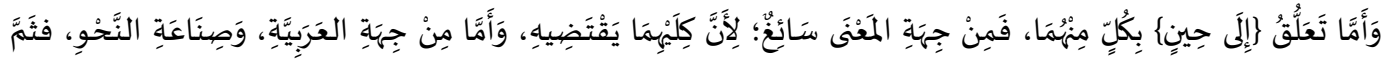

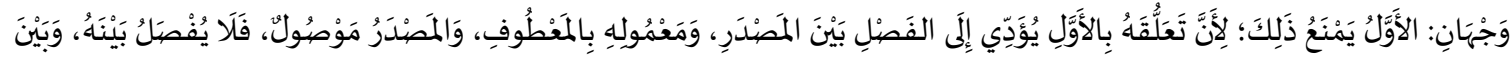

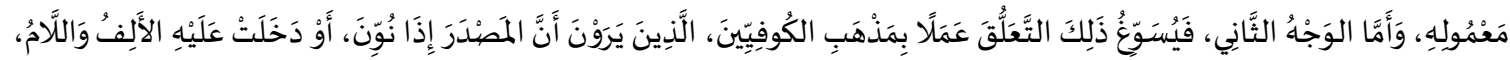

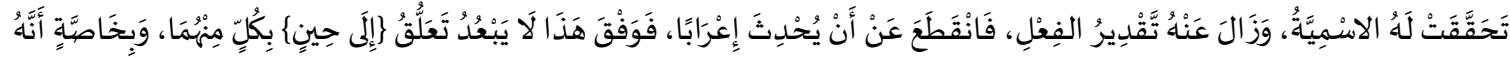

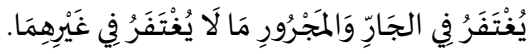

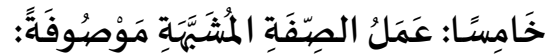

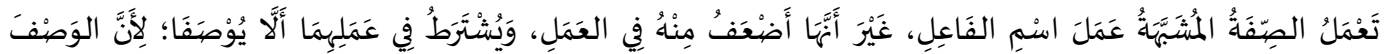

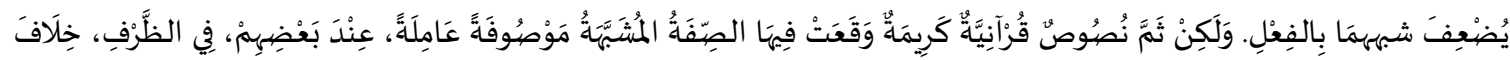

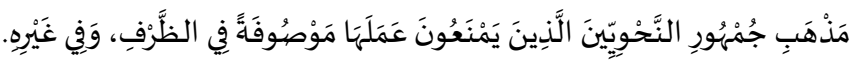

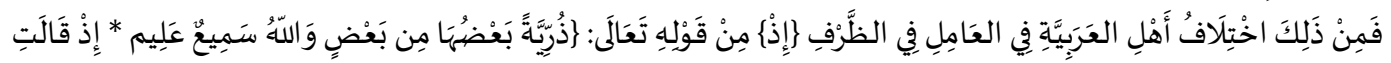

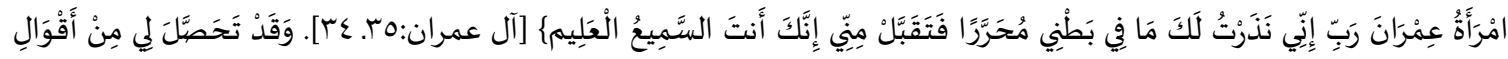

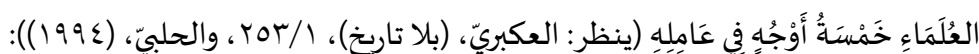

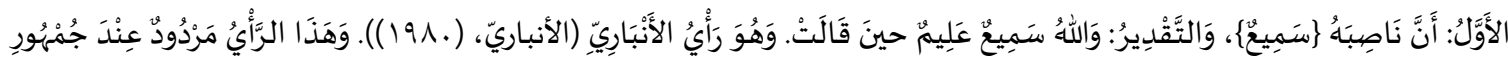

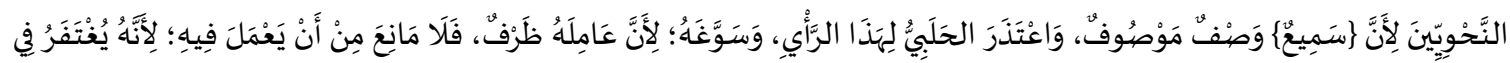

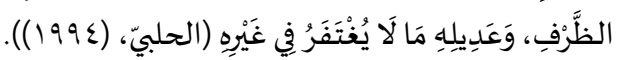

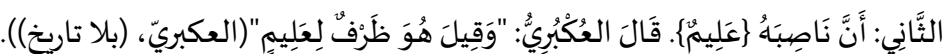

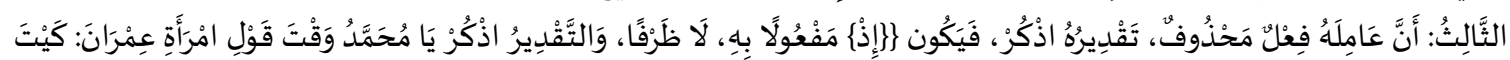

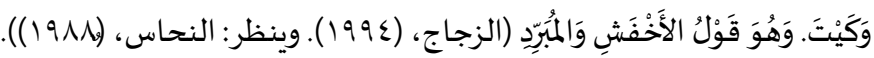

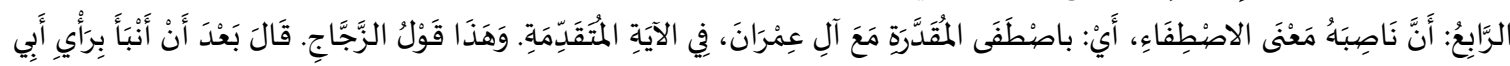

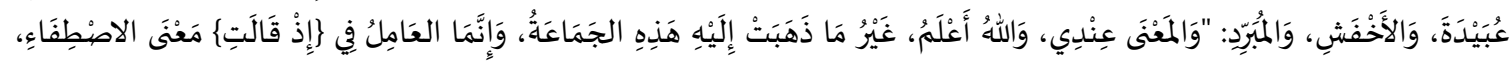

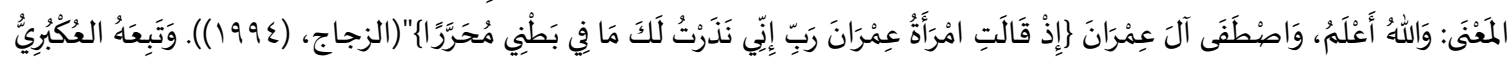

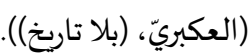

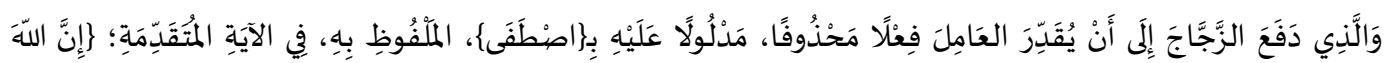

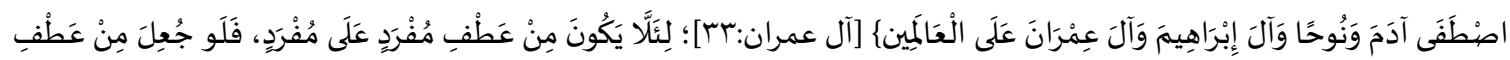

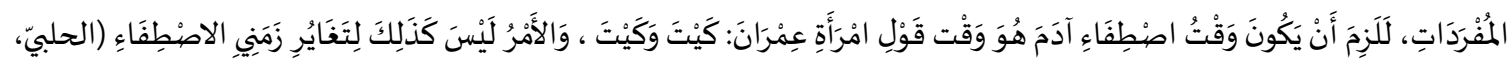

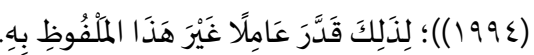

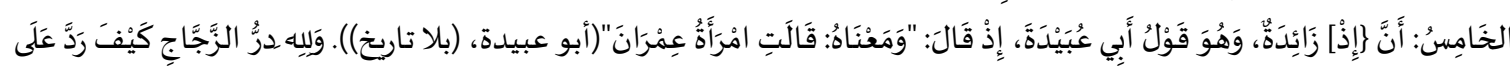

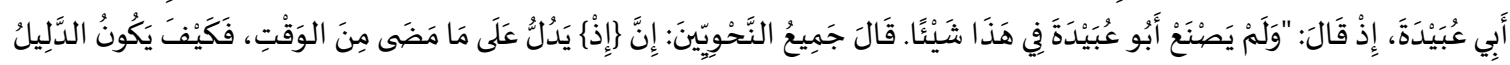

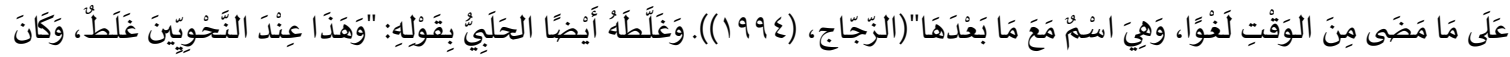

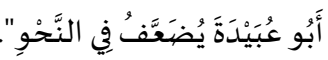




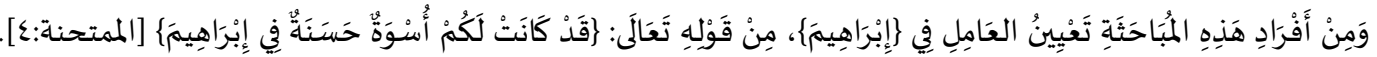

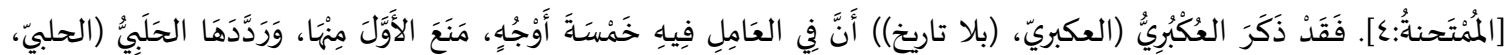

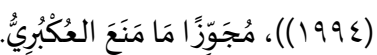

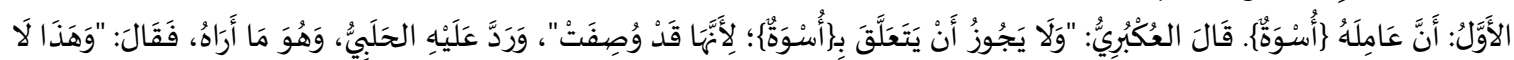

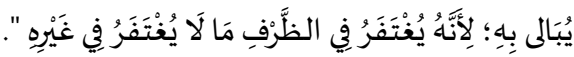

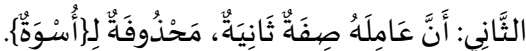

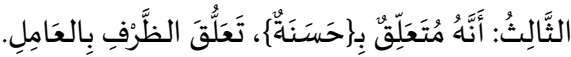

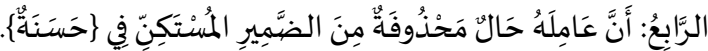

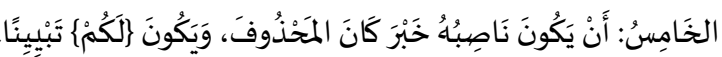

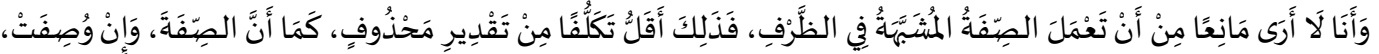

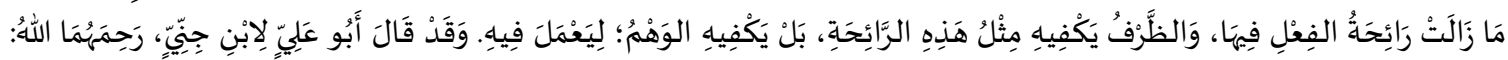

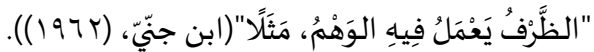

\section{سَادِسًا: حَذْفُ الظَُّرْفِ، وَتَقَاءُ عَامِلِهِ:}

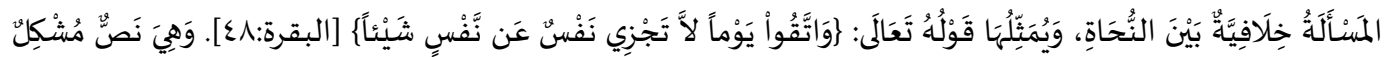

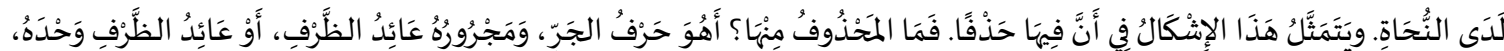

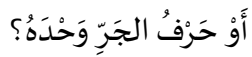

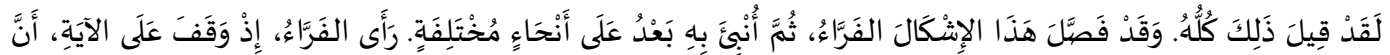

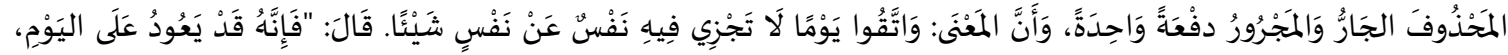

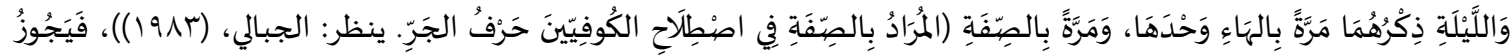

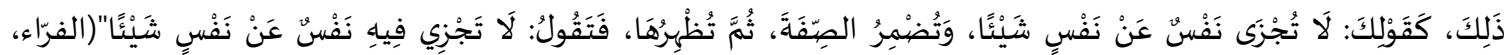

.$((191)$.

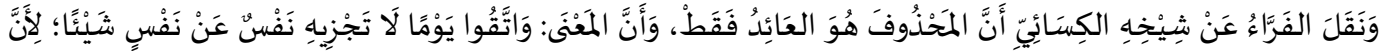

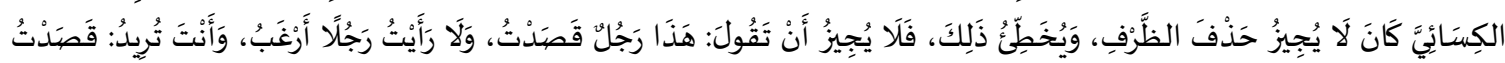

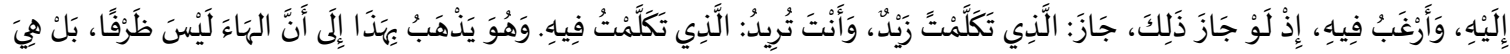

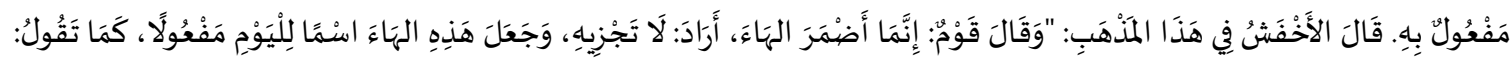

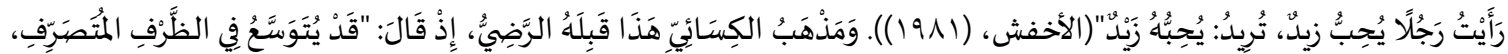

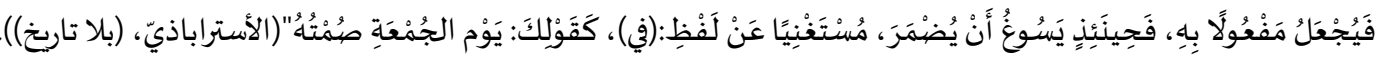

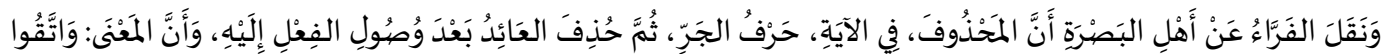

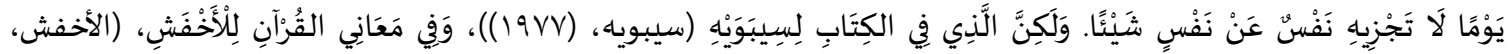

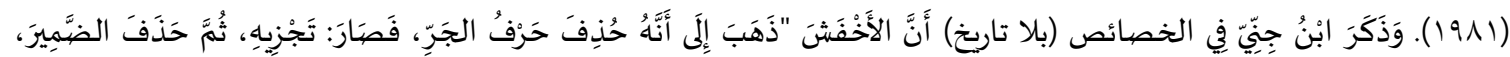

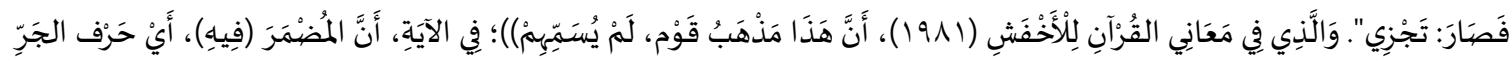

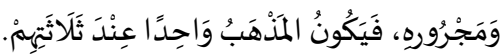

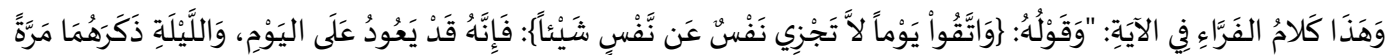

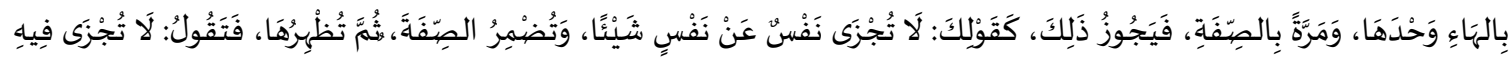

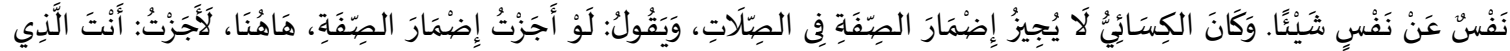

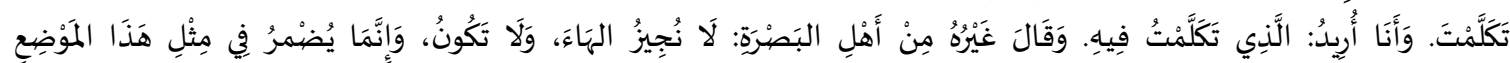

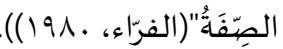

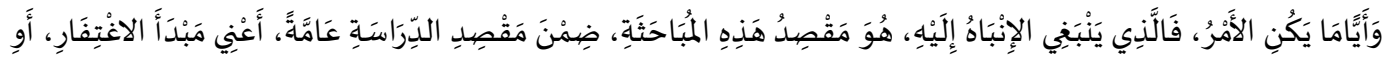

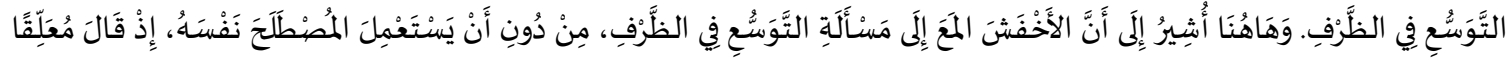

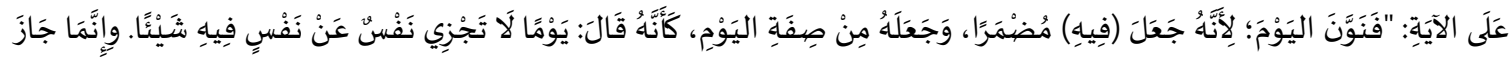




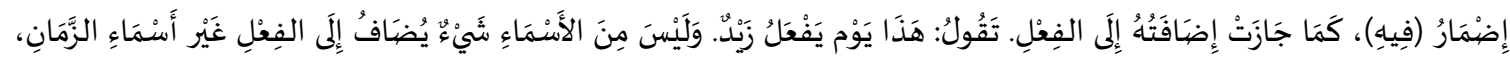

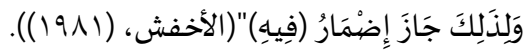

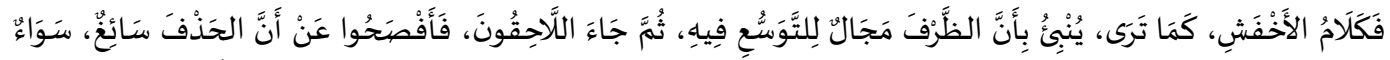

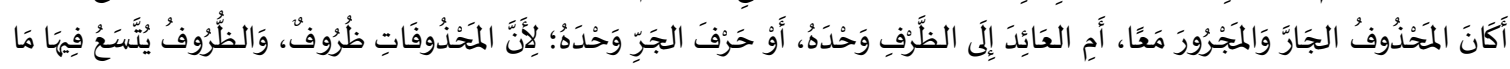

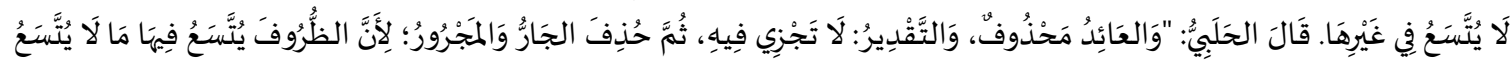

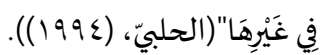

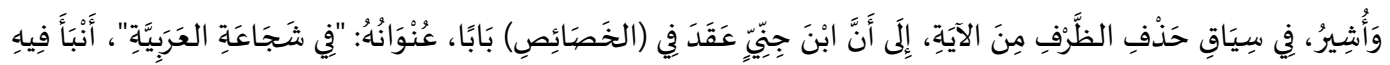

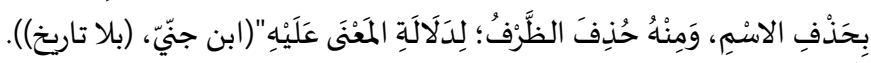

خَاتِمَةُّ:

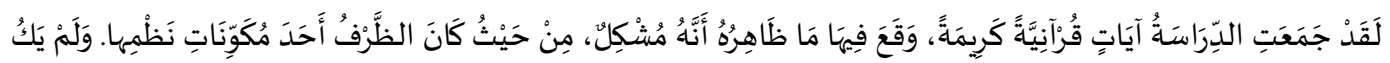

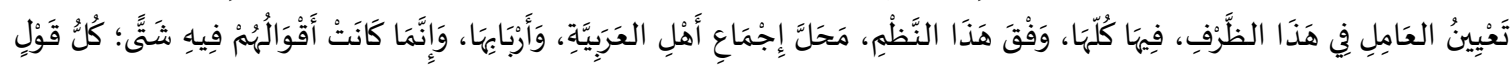

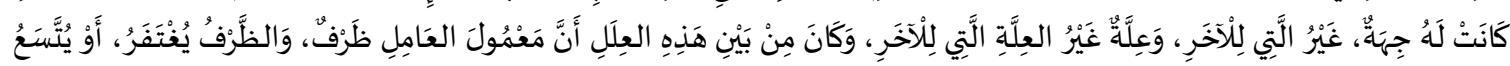

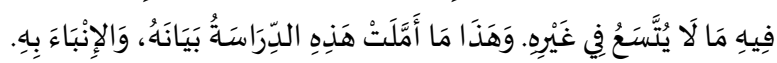

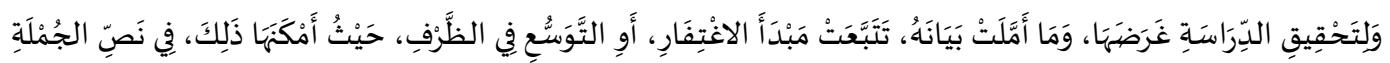

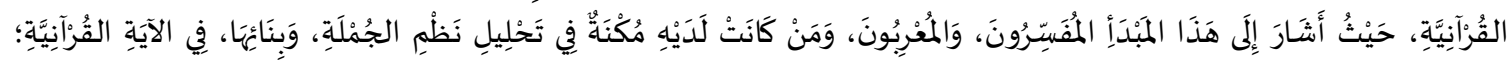

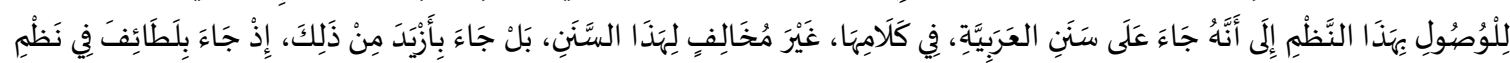

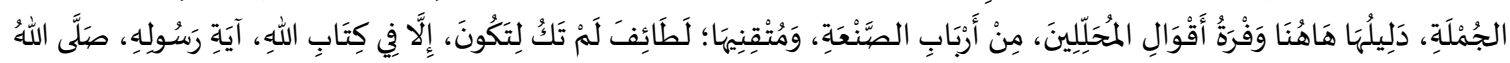

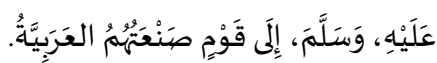

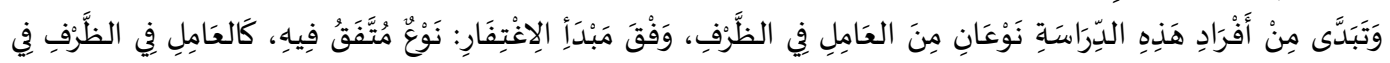

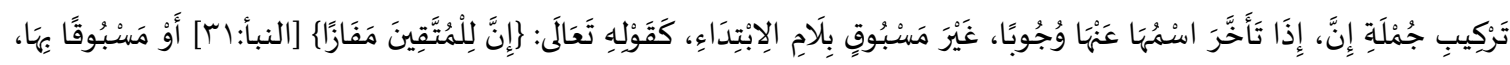

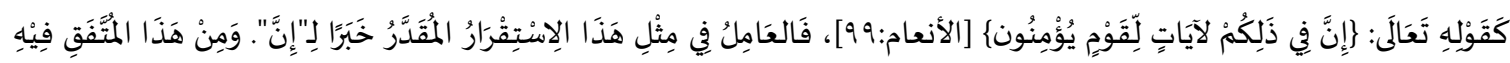

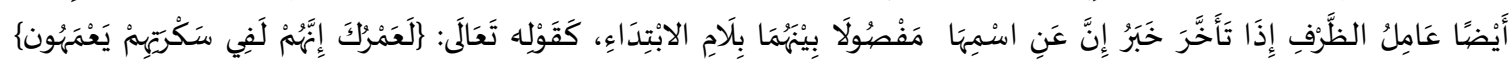

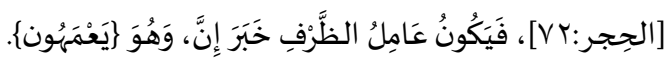

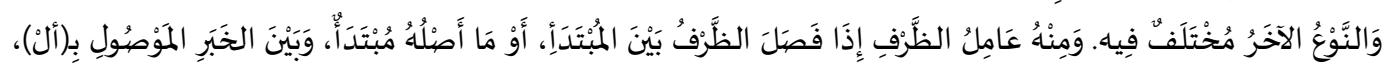

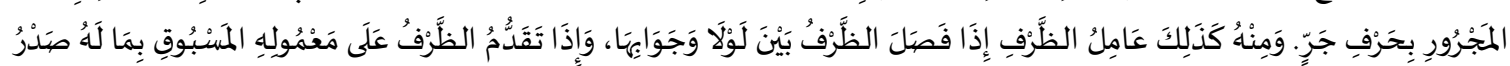

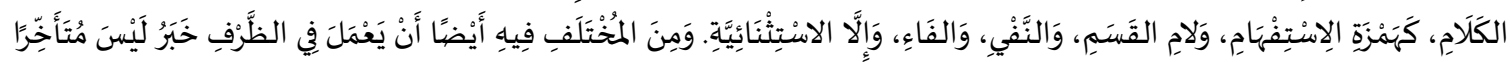

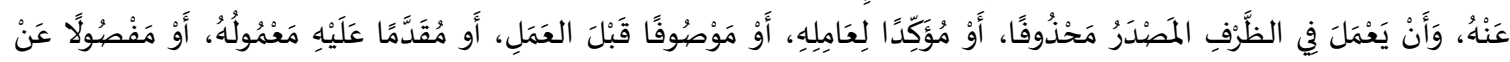

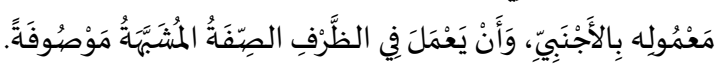

ا. الآلوسيّ، م، (0 اءعا اهـ) روح المعاني في تفسير القرآن العظيم والسّبع المثاني، تحقيق علي عبد الباري عطيّة، بيروت، دار الكتب

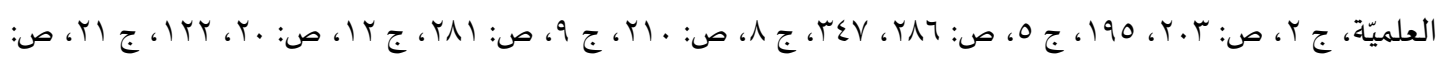
(

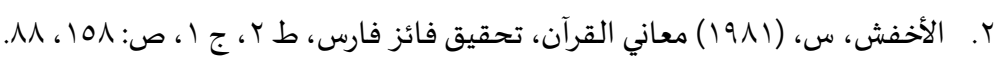

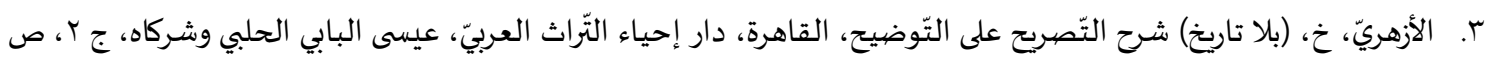
r.7.

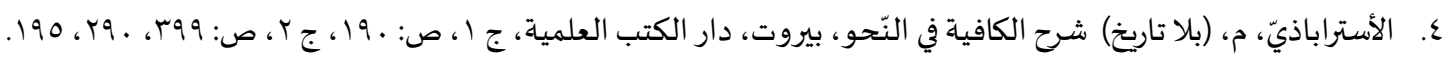

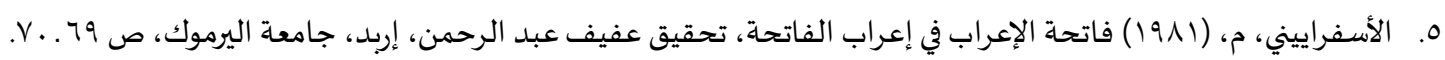

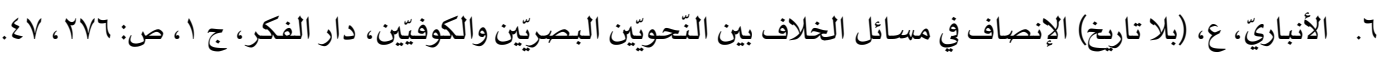


V V. الأنباريّ، ع، (.919)، البيان في غريب إعراب القرآن، تحقيق طه عبد الحميد طه، القاهرة، الهيئة المصريّة العامّة للكتاب، ج

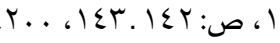

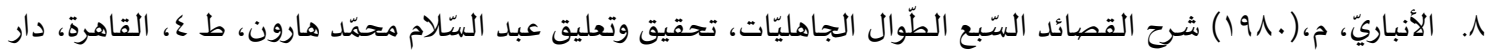

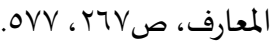

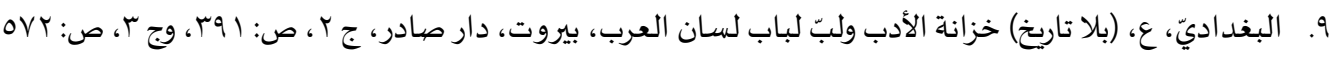

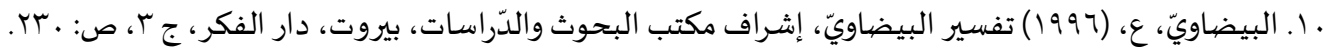

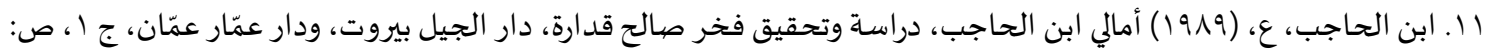

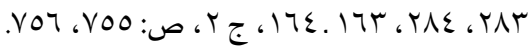

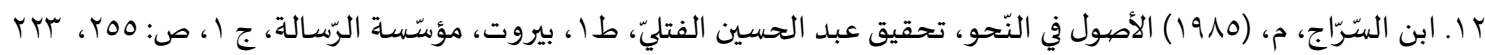

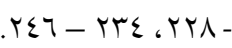

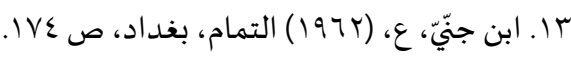

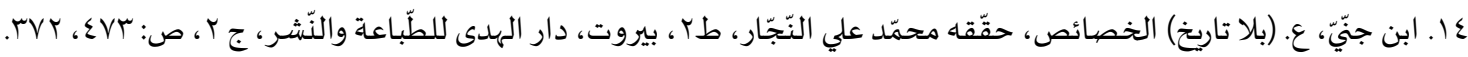

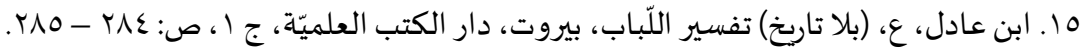

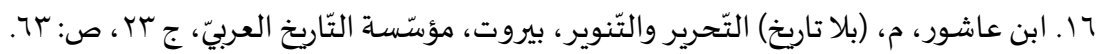

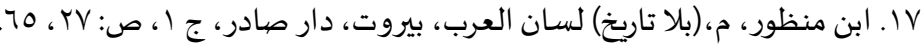

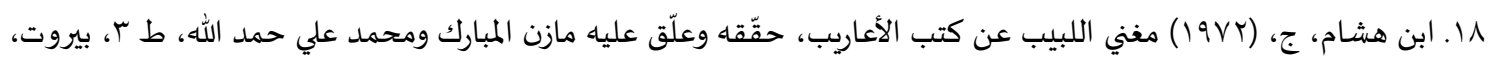

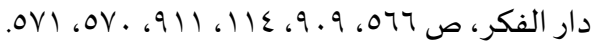

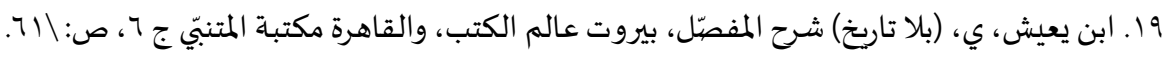

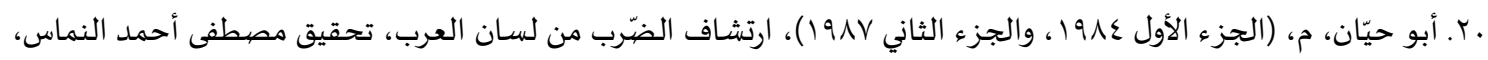

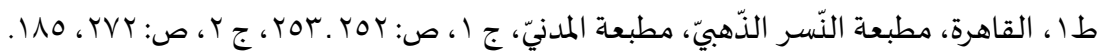

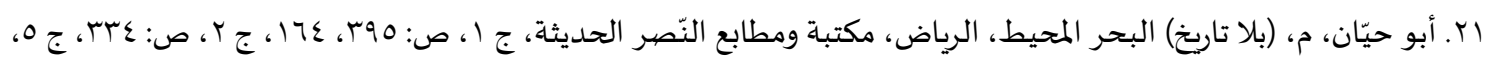

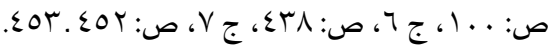

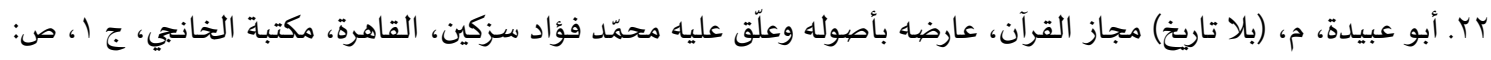

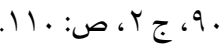

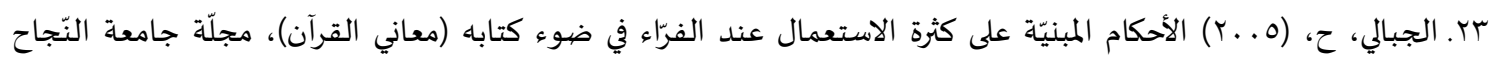

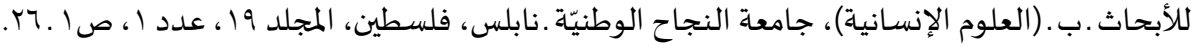

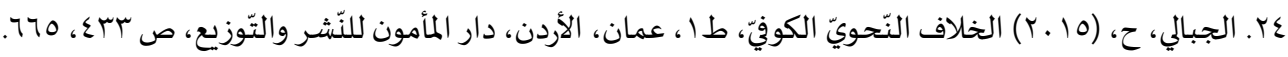

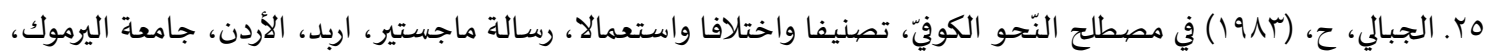
. 7r. الجبالي، ح، (999 199 الفصل النّحويّ، ظواهره وعلله، مجلّة جامعة النّجاح للأبحاث ـ ب (العلوم الإنسانية)، جامعة النّجاح

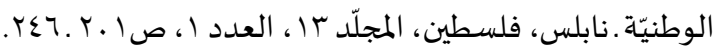

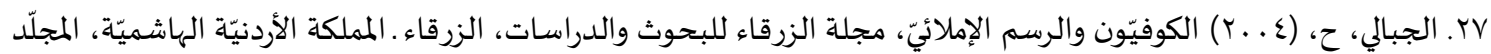

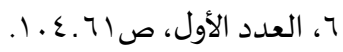

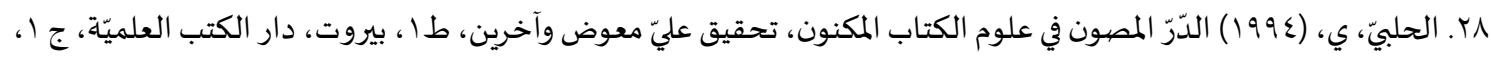
ص: عVr,

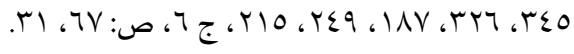
9r. الخفاجي، أ، (بلا تاريخ) حاشية الشُّهاب على تفسير البيضاوي، المسمّاة، عناية الرّاضي وكفاية القاضي على تفسير البيضاوي،

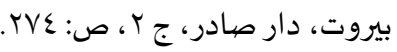

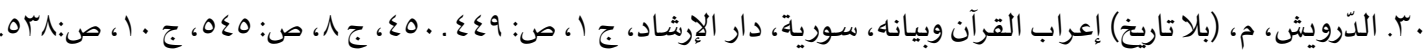

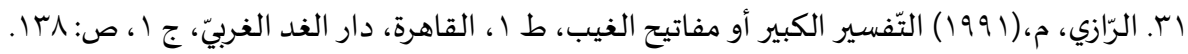

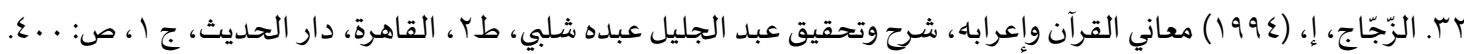




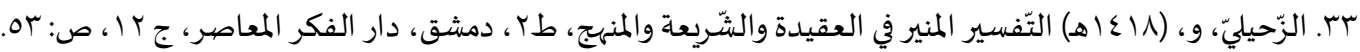

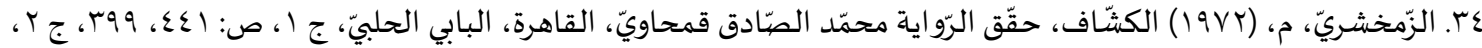
ص: ص:

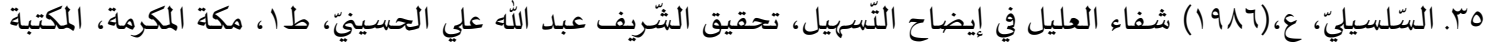

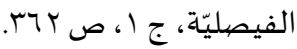

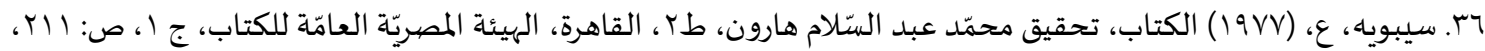
rरT

VV. السّيوطيّ، ع، (19 1) الأشباه والنّظائر، حقّقه طه عبد الرّؤوف سعد، القاهرة، مكتبة الكليّّات الأزهريّة، ج ا، ص: ع ا، ج ؟، ص: 177.

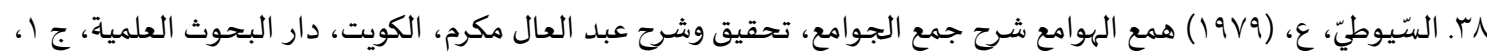

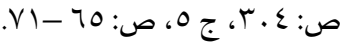

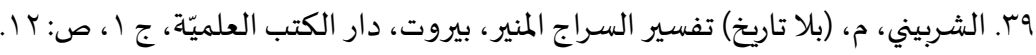

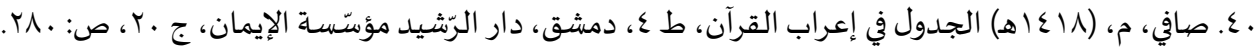

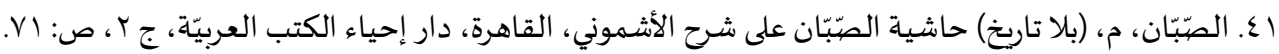

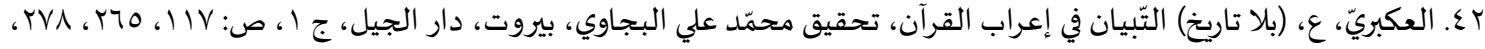

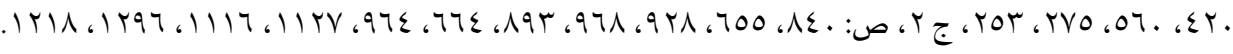

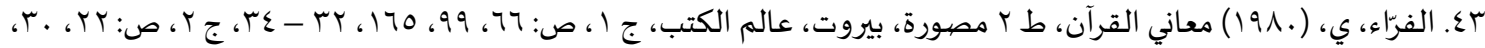

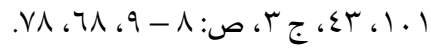

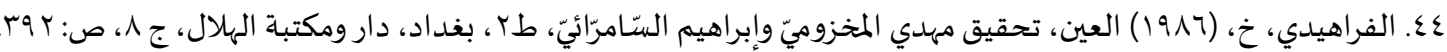

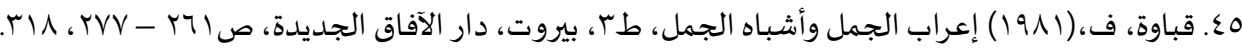

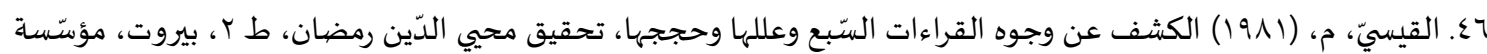

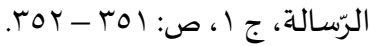
VV... المبرّد، م، (199V) الكامل في اللّغة والأدب، عارضها بأصوله وعلّق عليه محمّد أبو الفضل إبراهيم، طا ، بيروت، المكتبة

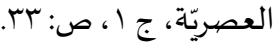

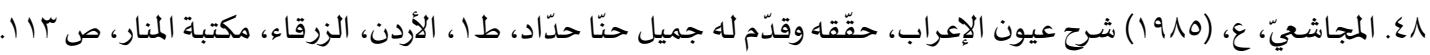

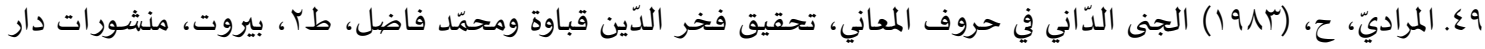

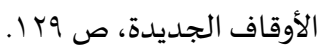

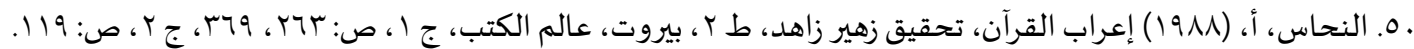


Refaad

رفاد للدراسات والأبحاث www.refaad.com
المجلة الدولية للدراسات اللغوية والأدبية العربية

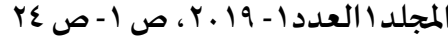

https://doi.org/DOI:10.31559/JALLS2019.1.1.1

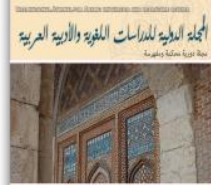

(1)

\section{The Key Factor in Adverbs: A Study in Qur'anic Text in the Light of "What is Plausible in Adverbs is not so Anywhere Else" Principle}

\section{Hamdi Mahmoud Jabali}

Professor of Arabic Language Department- Faculty of Arts- An-Najah National UniversityPalestine

hamdi.jabali@najah.edu

Abstract: $\quad$ This study traces Qur'anic verses that contain seemingly problematic issues in terms of the fact that the adverb is one of their constituents. Allocating the adverbial key factor in such verses has never gained Arabic linguists' unanimity at all; these linguists have had different perspectives and different explanations as well. The main objective of this study is to prove that among these perspectives is the affected entity is an adverb and that adverbs are plausible and capable of containing anything better than any other function word in Arabic. The current study is consistent with other related literature in the sense that all have shown that the Qur'anic text, unlike any other text, is smoothly and tenderly composed and directed to the Arabs. The most important results of the study are:

[1] The study follows the "what is allowed in adverbs is not so anywhere else" principle tracing all Qur'anic verses, where possible, and taking into considerations all ideas suggested by grammarian exegetists, syntacticians or grammarians, morphologists and linguists who are capable of analyzing the structure and sentence systems of Qur'anic verse.

[2] This study clearly reveals that these grammarians have adopted this linguistic principle and used it to allocate the key factor that functions in adverbial structures which appeared to be problematic or ambiguous.

[3] The study also shows that using this principle is closer to the nature and true spirit of the Arabic language since it can't be interpreted and/or expected.

Keywords: Adverbs, Arabic, principle, Qur'an

\section{References:}

[1] Ạbn 'ạdl. ', Tfsyr Ạllioạb, Byrwt, Dạr Ạlktb Ạl 'lmỹh, J 1, pp. 284-285.

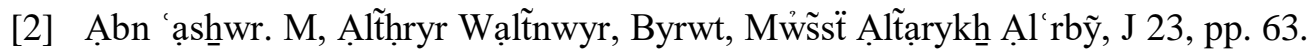

[3] Ạbn Ạlhạjb. ', Ạmạly Ạbn Ạlhạjb, Drạsï Wtḥqyq Fkḥr Șạlḥ Qdạrẗ, Dạr Ạljyl Byrwt, Wdạr 'mạar 'mạn, (1989), J 1, pp.283, 284, 163 164, J 2, pp. 755, 756.

[4] Ạbn Ạls̃rạj. M, Ạlạ̉ṣwl Fy Ạlñḥw, Tḥqyq 'bd Ạlḥsyn Ạlftlỹ, Ṭ1, Byrwt, Mw̉s̃̃üt Ạlr̃̃sạlh, (1985), J 1, pp. 255, 223 - 228, $234-246$.

[5] Ạbn Hshạam. J, Mghnny Ạllbyb 'n Ktb Ạlạ̉ ạryb, Ḥqqqh W' ̃q 'lyh Mạzn Ạlmbạrk Wmḥmd 'ly Ḥmd Ạllh, T 3, Byrwt, Dạr Ạlfkr, (1972), pp.566, 909, 114, 911, 570, 571.

[6] Ạbn Jñỹ. ', Ạlkḥṣậș, Hãqh Mḥm̃ 'ly Ạlñjạar, Ṭ2, Byrwt, Dạr Ạlhdy Llṭ̃bạ h Wạlñsh̆r, J 2, pp. 473, 372. 
[7] Ạbn Jñỹ. ', Altmạm, Bgḥdạd, (1962), pp. 174.

[8] Ạbn Mnẓwr. M, Lsạn Ạl'rb, Byrwt, Dạr Șạdr, J 1, pp. 27, 65.

[9] Ạbn Y'ysh̆. Y, Sḥrḥ Ạlmfṣ̃l, Byrwt 'ạlm Ạlktb, Wạlqạhrh Mktbẗ Ạlmtnb̃y J 6, pp.61.

[10] Ạ̉bw Hỹạn. M, Ạlbḥr Ạlmhyyṭ, Ạlryạd, Mktbẗ Wmțạb Ạlñṣr Ạlhdytḥh, J 1, pp. 395, 164, J 2, pp. 334, J 5, pp. 100, J 6, pp. 438, J 7, pp. 452453.

[11] Ạ̉bw Hỹạn. M, Artshạaf Ạlạ̃rb Mn Lsạn Ạl'rb, Thqyq Mṣṭy Ạ̉hmd Ạlnmạs, Ṭ1, Ạlqạhrh,

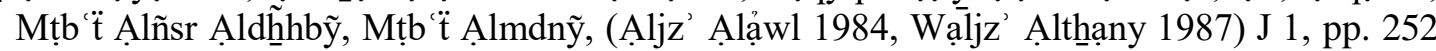
253, J 2, pp. 272, 185.

[12] Ạ̉bw 'bydh. M, Mjạz Ạlqrận, 'ạrḍh Bạ̉ṣwlh W' ̃̃q 'lyh Mḥmend Fw̉ạd Szkyn, Ạlqạhrh, Mktbë Ạlkhạjy, J 1, pp. 90, J 2, pp. 110.

[13] Ạl'kbrỹ. ', Alițbyạn Fy A 'rạb Ạlqrận, Thquyq Mḥmond 'ly Albjạwy, Byrwt, Dạr Ạljyl, J 1, pp. 117, 265, 278, 420, 560, 275, 253, J 2, pp. 840, 655, 928, 968, 893, 664, 964, 1127, 1116, $1296,1218$.

[14] Alậlwsỹ. M, Rwh Ạlm'ạny Fy Tfsyr Ạlqrận Ạl'zym Wạls̃u' Ạlmthạny, Tḥqyq 'ly 'bd Ạlbạry 'ṭ̃h, Byrwt, Dạr Ạlktb Ạl'lmỹh, (1415h), J 2, pp.203, 195, J 5, pp. 286, 347, J 8, pp. 210, J 9, pp. 281, J 12, pp. 20, 122, J 21, pp. 123, J 27, pp. 99, J 30, pp. 328.

[15] Ạlạ̉kḥfsh. S, M’ạny Ạlqrận, Tḥqyq Fạ̉y Fạrs, (1981), Ṭ 2, J 1, pp. 158, 88.

[16] Ạlạ̉nbạrỹ. ', ẠlậNșạf Fy Msạỷl Ạlkḥlạf Byn Ạlñḥwỹyn Ạlbṣrỹyn Wạlkwfỹyn, Dạr Ạlfkr, J 1 , pp. 276, 47.

[17] Alạ̉nbạrỹ.', Ạlbyạn Fy Ghryb Ạ̛ rạb Ạlqrận, Tḥqyq Ṭh 'bd Ạlḥmyd Ṭh, Ạlqạhrh, Ạlhyỷh ẠlmṣrỹhẠl'ậmh Llktạb, (1980), J 1, pp. 142 143, 200.

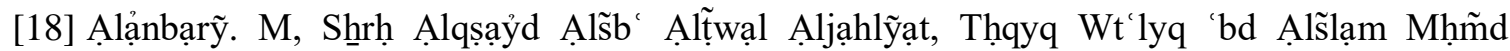
Hạrwn, Ṭ 4, Ạlqạhrh, Dạr Ạlm’ạrf, (1980), pp.267, 577.

[19] Ạlạ̉sfrạyyny. M, Fạtḥ̆ Ạlạ rạb Fy Ạ rạb Ạlfạtḥh, Tḥqyq 'fyf 'bd Ạlrḥmn, ẠRbd, Jạm ‘̇ A.lyrmwk, (1981), pp. 69, 70.

[20] Alạ̉strạbạdhnỹ. M, Sḥrḥ Ạlkạfyh Fy Ạlñḥw, Byrwt, Dạr Ạlktb Ạl'lmyh, J 1, pp. 190, J 2, pp. 399, 290, 195.

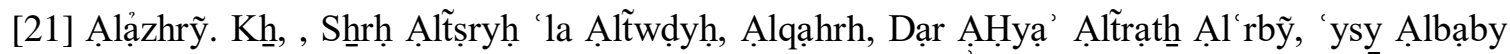
Ạlḥlby Wshrkạh, J 2, pp.62, 63.

[22] Ạlbghndạdỹ. ', Khnzạnẗ Ạlạ̉db Wlb Lbạb Lsạn Ạl'rb, Byrwt, Dạr Ṣạdr, J 2, pp. 391, j 3, pp. 572.

[23] Ạlbyḍ̣awỹ. ', Tfsyr Ạlbyḍạwỹ, A̧Sḥrạf Mktb Ạlbḥwtḥ Wạld̃ạasạt, Byrwt, Dạr Ạlfkr, (1996), J 3, pp. 230.

[24] Ạld̃rwysh. M, A 'rạb Ạlqrận Wbyạnh, Swryh, Dạr ẠlậRshạd, J 1, pp. 449 450, J 8, pp. 545, J 10, pp.538.

[25] Ạlfrạa'. Y, M'ạny Ạlqrận, Ṭ 2 Mṣwrh, Byrwt, 'ạlm Ạlktb, (1980), J 1, pp. 66, 99, 165, 32 34 , J 2, pp. 22, 30, 101, 43, J 3, pp. 8-9, 68, 78. 


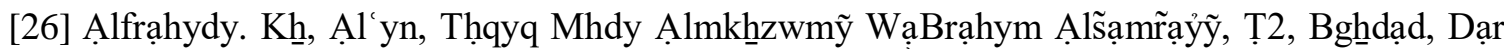
Wmktbë A.lhlạl, (1986), J 8, pp. 392.

[27] Ạlḥlbỹ. Y, Ạlã̃ Ạlmṣwn Fy 'lwm Ạlktạb Ạlmknwn, Tḥyq 'lỹ M'wọ Wậkh̄ryn, Ṭ1, Byrwt, Dạr A.lktb A.l'lmỹh, (1994), J 1, pp. 374, 496, 214, J 2, pp. 491, 144, 70 71, J 3, pp. 248, 249, 464, 304, J 4, pp. 440, 91, J 5, pp. 345, 326, 187, 249, 215, J 6, pp. 67, 31.

[28] Aljbạly. H, Alạ̉hkạm Ạlmbnỹh 'la Kthnrë Alạst'mạl 'nd Alfrạa' Fy Dw' Ktạbh (M'ạny

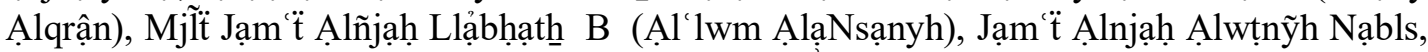
Flstyn, 19(1) (2005), pp.1 26.

[29] Ạljbạly. Ḥ, Ạlkḥlạf Ạlñḥwỹ Ạlkwfỹ, Ṭ1, 'mạn, Ạlạ̉rdn, Dạr Ạlmạ̉mwn Llñsḥr Wạlttwzy', (2015), pp. 433, 665.

[30] Ạljbạly. Ḥ, Ạlkwfỹwn Wạlrsm ẠlạMlạyỹỹ, Mjlt Ạlzrqạ' Llbḥwth Wạldrạsạt, Ạlzrqạa' Ạlmmlkh Ạlạ̉rdnỹh Ạlhạshnmỹh, 6(1)(2004), pp.61 104.

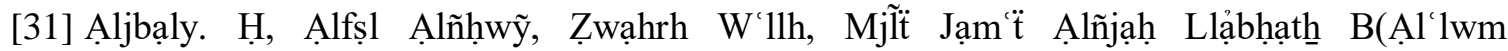
ẠlậNsạnyh), Jạm đ̈ Ạlñjạ̣ Ạlwṭnỹt Nạbls, Flsțyn, (13)(1)(1999), pp.201 246.

[32] Aljbạly. Ḥ, Fy Mṣṭlh Ạlñḥw Ạlkwfỹ, Tṣnyfạ Wạkḥtlạfạ Wạst mạlạ, Rsạlẗ Mạjstyr, Ạrbd, Ạlạ̉rdn, Jạm $\dddot{t}$ A.lyrmwk, (1983), pp.70.

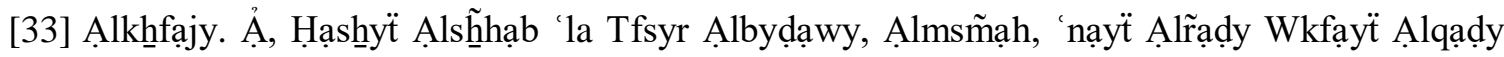
'la Tfsyr Ạlbyḍạwy, Byrwt, Dạr Șạdr, J 2, pp. 274.

[34] Ạlmbr̃̃d. M, Ạlkạml Fy Ạlĩghh Wạlạ̉db, ‘ạrḍh Bạ̉ṣwlh W“ĩq 'lyh Mḥmd Ạ̉bw Ạlfụl ÄBrạhym, T1, Byrwt, A.lmktbh Ạl'ṣrỹh, (1997), J 1, pp.33.

[35] Ạlmjạsh 'ỹ. ', Shhrḥ 'ywn Ạlạ rạb, Ḥqqqh Wqãm Lh Jmyl Ḥnạa Ḥ̃ạạ, Ṭ1, Ạlạ̉rdn, Ạlzrqạ', Mktbö Ạlmnạr, (1985), pp.113.

[36] Ạlmrạdỹ. H, Aljny Ạldạny Fy Ḥrwf Ạlm ‘ạny, Tḥqyq Fkh̆r Ạld̃yn Qbạwh Wmḥm̃̃ Fạ̣̣l, Ṭ2, Byrwt, Mnshowrạt Dạr Ạlạ̉wqạf Ạljdydh, (1983), pp.129.

[37] Ạlnhạs. Ả, Árạb Ạlqrận, Tḥyq Zhyr Zạhd, Ṭ 2, Byrwt, 'ạlm Ạlktb, (1988), J 1, pp. 263, 369, J 2, pp. 119.

[38] Ạlqysỹ. M, Ạlkshff 'n Wjwh Ạlqrạ'ạt Ạls̃s' W'llhạ Whijjhạ, Thqqyq Mḥyy Ạld̃yn Rmḍạn, T 2, Byrwt, Mw̃s̃sẗ Ạlr̃sạlh, (1981), J 1, pp.351-352.

[39] Ạlrạazy. M, Ạlt̃fsyr Ạlkbyr Ạ̉w Mfạtyḥ Ạlghnyb, Ṭ 1, Ạlqạhrh, Dạr Ạlghnd Ạlghrrbỹ, (1991), J 1, pp. 138.

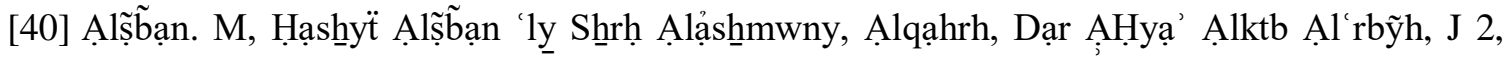
pp. 71.

[41] Ạlsḥrbyny. M, Tfsyr Ạlsrạj Ạlmnyr, Byrwt, Dạr Ạlktb Ạl'lmỹh, J 1, pp. 12.

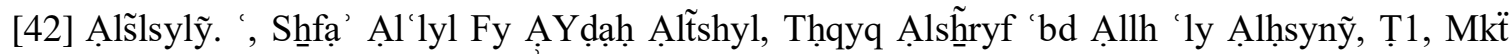
Ạlmkrmü, Ạlmktbë Ạlfyṣlỹh, (1986), J 1, pp.362.

[43] Ạls̃ywț̃y. ', Ạlạ̉shַbạh Wạlñzạỷr, Hạqqh Ṭh 'bd Ạlr̃ủwo S'd, Ạlqạhrh, Mktbë Ạlkĩỹạt Ạlạ̉zhrỹh, (1975), J 1, pp. 14, J 3, pp. 166. 
[44] Ạls̃ywțỹ. ', Hm` Ạlhwạm Sḥrḥ Jm’ Ạljwạm', Tḥqyq Wshrhḥ 'bd Ạl'ạl Mkrm, Ạlkwyt, Dạr A.lbḥwth A. Al'lmyh, (1979), J 1, pp. 304, J 5, pp. 65 -71.

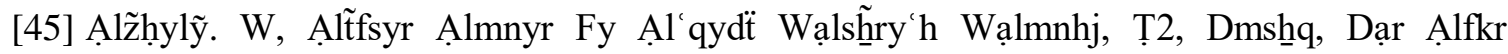
Ạlm ‘̣̣șr, (1418h), J 12, pp.53.

[46] Ạlžjạj. Ạ, M'ạny Ạlqrận Wạ rạabh, Shbrḥ Wtḥqyq 'bd Ạljlyl 'bdh Shllby, Ṭ2, Ạlqạhrh, Dạr Ạlḥ̂thth, (1994), J 1, pp. 400.

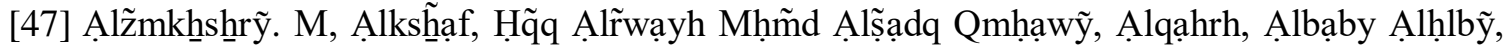
(1972), J 1, pp. 441, 399, J 2, pp. 176, 265, 260, 308, 541, J 3, pp. 54 55, 585, 347, 417.

[48] Qbạwh. F, Ạ rạb Ạljml Wạ̉shbbạh Ạljml, Ṭ3, Byrwt, Dạr Ạlậfạq Ạljdydh, (1981), pp.261$277,318$.

[49] Șạfy. M, Ạljdwl Fy Ạ rạb Ạlqrận, Ṭ 4, Dmsh̆q, Dạr Ạlr̃̃shyd Mw̉s̃sï Ạlậmạn, (1418h), J 20 , pp. 280.

[50] Sybwyh. ', Ạlktạb, Tḥqyq Mḥmd 'bd Ạls̃lạm Hạrwn, Ṭ2, Ạlqạhrh, Ạlhyỷh Ạlmșrỹh Ạl'ạmu Llktạb, (1977), J 1, pp. 211, 386. 